Prepared for the U.S. Department of Energy

under Contract DE-AC05-76RL01830

\title{
Non-Pertechnetate Technetium Sensor Research and Development
}

\author{
SA Bryan BM Rapko \\ AD Crawford SD Branch ${ }^{1}$ \\ WR Heineman ${ }^{1}$
}

${ }^{1}$ University of Cincinnati, Cincinnati, $\mathrm{OH}$

September 2014

Pacific Northwest

NATIONAL LABORATORY

Proudly Operated by Battelle Since 1965 


\title{
DISCLAIMER
}

This report was prepared as an account of work sponsored by an agency of the United States Government. Neither the United States Government nor any agency thereof, nor Battelle Memorial Institute, nor any of their employees, makes any warranty, express or implied, or assumes any legal liability or responsibility for the accuracy, completeness, or usefulness of any information, apparatus, product, or process disclosed, or represents that its use would not infringe privately owned rights. Reference herein to any specific commercial product, process, or service by trade name, trademark, manufacturer, or otherwise does not necessarily constitute or imply its endorsement, recommendation, or favoring by the United States Government or any agency thereof, or Battelle Memorial Institute. The views and opinions of authors expressed herein do not necessarily state or reflect those of the United States Government or any agency thereof.

\author{
PACIFIC NORTHWEST NATIONAL LABORATORY \\ operated by \\ BATTELLE \\ for the \\ UNITED STATES DEPARTMENT OF ENERGY \\ under Contract DE-AC05-76RL01830 \\ Printed in the United States of America
Available to DOE and DOE contractors from the Office of Scientific and Technical Information, P.O. Box 62, Oak Ridge, TN 37831-0062; ph: (865) 576-8401 fax: (865) 576-5728 email: reports@adonis.osti.gov \\ Available to the public from the National Technical Information Service \\ 5301 Shawnee Rd., Alexandria, VA 22312 \\ ph: (800) 553-NTIS (6847) \\ email: orders@ntis.gov <http://www.ntis.gov/about/form.aspx> \\ Online ordering: http://www.ntis.gov
}




\title{
Non-Pertechnetate Technetium Sensor Research and Development
}

\author{
SA Bryan \\ BM Rapko \\ AD Crawford \\ SD Branch ${ }^{1}$ \\ WR Heineman ${ }^{1}$
}

${ }^{1}$ University of Cincinnati, Cincinnati $\mathrm{OH} 45221-0172$

September 2014

Prepared for

the U.S. Department of Energy

under Contract DE-AC05-76RL01830

Pacific Northwest National Laboratory

Richland, Washington 99352 



\section{Executive Summary}

There remain several significant uncertainties in the understanding and modeling of the fate and speciation of ${ }^{99} \mathrm{Tc}$ in Hanford waste tanks, glass, and low-temperature waste forms. A significant ( $2 \%$ to $25 \%$ ) fraction of the ${ }^{99} \mathrm{Tc}$ in the water-soluble portion of the tank waste may be present as a non-pertechnetate species that has not been identified and, based on experimentation to date, cannot be effectively separated from the wastes. This task will provide a sensor specifically tuned to detect the Tc(I)-carbonyl species believed to constitute the main fraction of the non-pertechnetate form of technetium. By direct measurement of the non-pertechnetate species, such a sensor will help reduce the uncertainties in the modeling of the fate and speciation of ${ }^{99} \mathrm{Tc}$ in Hanford tanks and waste forms.

This report summarizes work done in FY 2014 exploring the chemistry of a low-valence technetium species, $\left[\mathrm{Tc}(\mathrm{CO})_{3}\left(\mathrm{H}_{2} \mathrm{O}\right)_{3}\right]^{+}$, a compound of interest due to its implication in the speciation of alkaline-soluble technetium in several Hanford tank waste supernatants. Progress made in FY 2014 was sponsored by the Department of Energy's Office of Environmental Management and is summarized in this report.

This work involved examining the spectroscopic and electrochemical characteristics of a series of $\left[\mathrm{Tc}(\mathrm{L} \sim \mathrm{L})(\mathrm{CO})_{3}\left(\mathrm{H}_{2} \mathrm{O}\right)\right]^{+}$complexes and their Re analogs $\left[\operatorname{Re}(\mathrm{L} \sim \mathrm{L})(\mathrm{CO})_{3}\left(\mathrm{H}_{2} \mathrm{O}\right)\right]^{+}$(where $\mathrm{L} \sim \mathrm{L}=$ bpy, phen, or their derivatives), as relevant to the development of a spectroelectrochemical sensor based on fluorescence spectroscopy of $\left[\mathrm{Tc}(\mathrm{CO})_{3}\left(\mathrm{H}_{2} \mathrm{O}\right)_{3}\right]^{+}$. In FY 2014, we have demonstrated the general steps forming the basis for a spectroelectrochemical sensor.

Key outcomes from this year's work are:

1. Demonstrated the photoluminescence of a series of $\mathrm{Re}(\mathrm{I})$-carbonyl complexes, which are direct analogs to the $\mathrm{Tc}(\mathrm{I})$-carbonyl target complexes. These complexes are $\left[\operatorname{Re}(\mathrm{L} \cap \mathrm{L})(\mathrm{CO})_{3}\left(\mathrm{H}_{2} \mathrm{O}\right)\right]^{+}$(where $\mathrm{L} \sim \mathrm{L}$ is a bidentate ligand = bpy, dbbpy, dmeobpy, dmbpy, phen, or bpym). The detection limit for $\left[\operatorname{Re}(\text { bpy })(\mathrm{CO})_{3}\left(\mathrm{H}_{2} \mathrm{O}\right)\right]^{+}$was determined to be $9 \times 10^{-7} \mathrm{M}$.

Synthesized the Tc(I)-carbonyl species $\left[\mathrm{Tc}(\mathrm{bpy})(\mathrm{CO})_{3}\left(\mathrm{H}_{2} \mathrm{O}\right)\right]^{+}$and $\left[\mathrm{Tc}(\mathrm{phen})(\mathrm{CO})_{3}\left(\mathrm{H}_{2} \mathrm{O}\right)\right]^{+}$, and by comparison with the spectroscopic emission properties of the Re analogs, $\left[\mathrm{Re}(\mathrm{bpy})(\mathrm{CO})_{3}\left(\mathrm{H}_{2} \mathrm{O}\right)\right]^{+}$and $\left[\operatorname{Re}(\text { phen })(\mathrm{CO})_{3}\left(\mathrm{H}_{2} \mathrm{O}\right)\right]^{+}$, confirmed the formation of these target complexes.

To achieve the desired detection limits, fluorescent molecules are needed because fluorescence detection methods are many orders of magnitude more sensitive than other optical techniques. The fluorescence measurement of $\left[\mathrm{Tc}(\mathrm{bpy})(\mathrm{CO})_{3}\left(\mathrm{H}_{2} \mathrm{O}\right)\right]^{+}$and $\left[\mathrm{Tc}(\mathrm{phen})(\mathrm{CO})_{3}\left(\mathrm{H}_{2} \mathrm{O}\right)\right]^{+}$was performed, which demonstrates the ability to use these molecules as target analytes within the proposed fluorescence-based spectroelectrochemical sensor.

These findings are documented in Section 4.1.

2. Demonstrated the reversible electrochemistry for the two classes of $\operatorname{Re}(\mathrm{I})$ carbonyl complexes, $\left[\operatorname{Re}(\mathrm{L} \sim \mathrm{L})(\mathrm{CO})_{3}\left(\mathrm{H}_{2} \mathrm{O}\right)\right]^{+}$and $\operatorname{Re}(\mathrm{L} \sim \mathrm{L})(\mathrm{CO})_{3} \mathrm{Cl}$, (where $\mathrm{L} \sim \mathrm{L}$ is a bidentate ligand = bpy, dbbpy, dmeobpy, dmbpy, phen, or bpym).

To achieve required selectivity, reversible electrochemistry of target analyte complex is desired. Changing the oxidation state of the complex through reversible electrochemistry allows for the creation and quenching of the fluorescence signal from the sample. This changing signal, which is triggered through the electrochemical sensor, creates a modulated (on/off) signal within the sensor 
platform. The ability to monitor a changing (modulated) signal of the Tc analyte complex allows for the distinguishing of this signal from a constant fluorescence signal originating from a potential interfering species.

This work is summarized in Section 4.2.

3. Demonstrated the spectroelectrochemical detection of several complexes, showing the reversible electrochemical behavior is exhibited in the modulated photoluminescence of the optical signal.

By combining the reversible electrochemical reduction/oxidation of the target analyte complex while measuring the fluorescence signal spectroscopically, it is possible to monitor a changing (modulated) signal from the Tc analyte complex. The ability to perform combined spectroscopy and electrochemistry was demonstrated using fluorescence modulation of the $\left[\mathrm{Re}(\mathrm{bpy})(\mathrm{CO})_{3}\left(\mathrm{H}_{2} \mathrm{O}\right)\right] \mathrm{Br}$ in a spectroelectrochemical cell.

This work is summarized in Section 4.3.

4. Evaluated several polymer films and thicknesses for the application of selective uptake of Tc target complexes for use in the sensor apparatus. The selective uptake of $\left[\operatorname{Re}(\text { dmeobpy })(C O)_{3}\left(\mathrm{H}_{2} \mathrm{O}\right)\right]^{+}$and other model complexes into polymer films was successfully performed during spectroelectrochemical sensing, demonstrating the spectroelectrochemical sensor prototype.

In order to increase sensitivity and selectivity, we are evaluating several polymer films for the application of selective uptake of Tc target complexes for use in the sensor apparatus. The selective uptake of $\left[\operatorname{Re}(\text { dmeobpy })(\mathrm{CO})_{3}\left(\mathrm{H}_{2} \mathrm{O}\right)\right]^{+}$and other model complexes into polymer films was successfully performed during spectroelectrochemical sensing, demonstrating the spectroelectrochemical sensor prototype, including the selective partitioning film. The effect of varying the selective film thickness within the sensor was performed by using a series of ITO-electrodes, coated with variable thickness of Nafion material. Compared to an uncoated electrode, the increase in electrochemical signal using a model compound for a 25-nm, 70-nm, and 200-nm Nafion coating was $10 \times, 70 \times$, and $100 \times$ increase in signal, respectively.

This work is detailed in Section 4.4.

In summary, in FY 2014 proof-of-principle work was performed successfully for a prototype spectroelectrochemical sensor. 


\section{Acronyms and Abbreviations}

BASi

CV

DMF

DOE

DOE-EM

EMSP

FY

IDF

ITO

IUPAC

OTE

PNNL

R\&D

RPP

SEC

UC

WRPS
Bioanalytical Systems, Inc.

cyclic voltammogram

dimethyl formamide

U.S. Department of Energy

U.S. Department of Energy Office of Environmental Management

Environmental Management Support Program

fiscal year

Integrated Disposal Facility

indium tin oxide

International Union of Pure and Applied Chemistry

optically transparent electrode

Pacific Northwest National Laboratory

research and development

River Protection Project

spectroelectrochemical

University of Cincinnati

Washington River Protection Solutions 



\section{Contents}

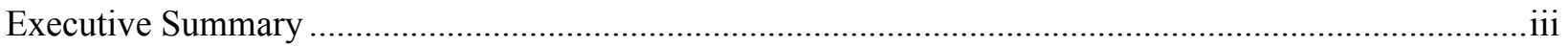

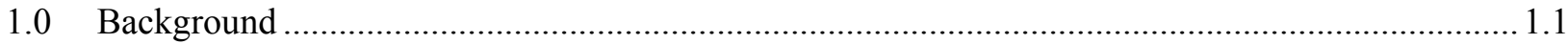

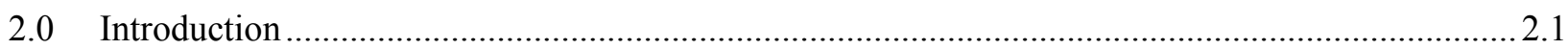

2.1 Concept for Detection of Non-pertechnetate Form of Technetium.................................... 2.1

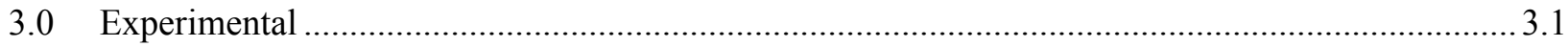

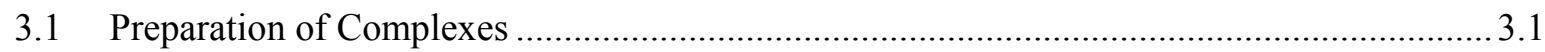

3.2 Electrochemistry, Spectroscopy, and Spectroelectrochemistry ....................................... 3.5

4.0 Sensor Development: Results and Discussion ....................................................................... 4.1

4.1 Optical Measurements of Tc and Re Complexes .......................................................... 4.1

4.2 Electrochemical Measurements of $\operatorname{Re}(\mathrm{L} \sim \mathrm{L})(\mathrm{CO})_{3} \mathrm{Cl}$ and $\left[\mathrm{Re}(\right.$ bpy $\left.)(\mathrm{CO})_{3}\left(\mathrm{H}_{2} \mathrm{O}\right)\right] \mathrm{Br}$

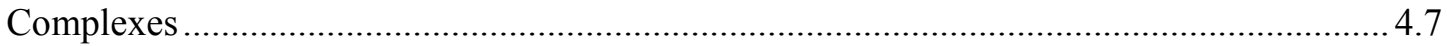

4.3 Spectroelectrochemical Measurements ........................................................................ 4.10

4.4 Selective Partitioning of Re-carbonyl and Other Model Complexes Into Ion-selective

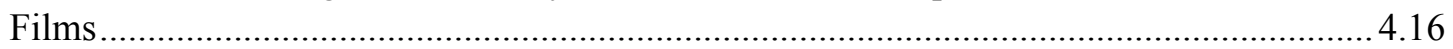

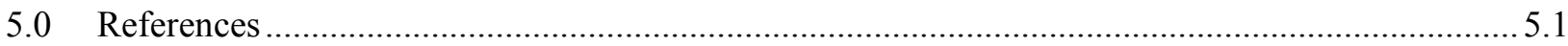




\section{Figures}

1.1. Structures of Pertechnetate and Technetium(I) tri-carbonyl-tris-aquo Cation ................................ 1.2

2.1. Concept for Detection of Non-pertechnetate Form of Technetium............................................. 2.2

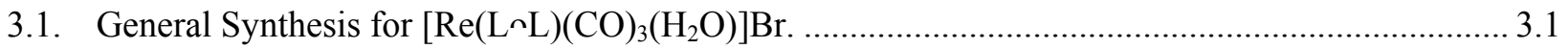

3.2. Synthesis for $\left[\mathrm{Tc}(\text { bpy })(\mathrm{CO})_{3}\left(\mathrm{H}_{2} \mathrm{O}\right)\right]^{+}$or $\left[\mathrm{Tc}(\mathrm{phen})(\mathrm{CO})_{3}\left(\mathrm{H}_{2} \mathrm{O}\right)\right]^{+}$Complexes................................ 3.2

3.3. List of Ligands Used for the Preparation of $\left[\operatorname{Re}(\mathrm{L} \sim \mathrm{L})(\mathrm{CO})_{3}\left(\mathrm{H}_{2} \mathrm{O}\right)\right]^{+}$or $\left[\mathrm{Tc}(\mathrm{L} \sim \mathrm{L})(\mathrm{CO})_{3}\left(\mathrm{H}_{2} \mathrm{O}\right)\right]^{+}$Complexes

3.4. Schematic of Absorbance-based Spectroelectrochemical Cell Showing Front View and Side View with Optical Path.

3.5. Photographs of Spectroelectrochemical Cell Showing Front View with Platinum Electrode Placed in Optical Path, Overhead View of Cuvette Showing Re(bpy) $(\mathrm{CO})_{3}\left(\mathrm{H}_{2} \mathrm{O}\right)^{+}$Complex in Solution Luminescing, and Oblique View Showing Cuvette in Holder with Optical Fibers Attached for Absorbance Mode Detection

3.6. Apparatus for Performing Spectroelectrochemical Measurements Showing the Location of the Electrochemical Potentiostat Adjacent to the Optical Components and Including Spectrometer and Cell Holder.

4.1. Excitation and Emission Spectra for $\operatorname{Re}(\mathrm{L} \sim \mathrm{L})(\mathrm{CO})_{3} \mathrm{Cl}$ Complexes Where $\mathrm{L} \cap \mathrm{L}=2,2$ '-bipyridine (bpy); 4,4'-di-tert-butyl-2,2'-bpy (dbbpy); 4,4'-dimethoxy-2,2'-bpy (dmeobpy); 4,4'-dimethyl-bpy (dmbpy); 1,10-phenanthroline (phen); and 2,2'-bipyrimidine (bpym).....

4.2. Absorption Spectra of $\left[\mathrm{Re}(\mathrm{L} \cap \mathrm{L})(\mathrm{CO})_{3}\left(\mathrm{H}_{2} \mathrm{O}\right)\right] \mathrm{Br}$ Complexes Where $\mathrm{L} \cap \mathrm{L}=2,2^{\prime}$ '-bipyridine (bpy); 4,4'-di-tert-butyl-2,2'-bpy (dbbpy); 4,4'-dimethoxy-2,2'-bpy (dmeobpy); 4,4'-dimethyl-bpy (dmbpy); 1,10-phenanthroline (phen); and 2,2'-bipyrimidine (bpym), and the Model $\mathrm{Ru}(\mathrm{bpy})_{2} \mathrm{Cl}_{2}$ Complex

4.3. Excitation Spectra for $\left[\mathrm{Re}(\mathrm{L} \sim \mathrm{L})(\mathrm{CO})_{3}\left(\mathrm{H}_{2} \mathrm{O}\right)\right] \mathrm{Br}$ Complexes Where $\mathrm{L} \sim \mathrm{L}=2,2^{\prime}$ '-bipyridine (bpy); 4,4'-di-tert-butyl-2,2'-bpy (dbbpy); 4,4'-dimethoxy-2,2'-bpy (dmeobpy); 4,4'-dimethyl-bpy (dmbpy); 1,10-phenanthroline (phen); and 2,2'-bipyrimidine (bpym)

4.4. Emission Spectra for $\left[\mathrm{Re}(\mathrm{L} \cap \mathrm{L})(\mathrm{CO})_{3}\left(\mathrm{H}_{2} \mathrm{O}\right)\right] \mathrm{Br}$ Complexes $(450 \mathrm{~nm}$ excitation) Where $\mathrm{L} \cap \mathrm{L}=$ 2,2'-bipyridine (bpy); 4,4'-di-tert-butyl-2,2'-bpy (dbbpy); 4,4'-dimethoxy-2,2'-bpy (dmeobpy); 4,4'-dimethyl-bpy (dmbpy); 1,10-phenanthroline (phen); and 2,2'-bipyrimidine (bpym)

4.5. Plot of $\log \left(\right.$ emission) versus $\log$ (concentration) of $\left[\mathrm{Re}(\right.$ bpy $\left.)(\mathrm{CO})_{3}\left(\mathrm{H}_{2} \mathrm{O}\right)\right] \mathrm{Br}$ in Aqueous Solution

4.6. Emission Spectral Overlay of $\left[\mathrm{Tc}(\mathrm{bpy})(\mathrm{CO})_{3}\left(\mathrm{H}_{2} \mathrm{O}\right)\right]^{+}$and $\left[\mathrm{Re}(\mathrm{bpy})(\mathrm{CO})_{3}\left(\mathrm{H}_{2} \mathrm{O}\right)\right]^{+}$, and $\left[\mathrm{Tc}(\text { phen })(\mathrm{CO})_{3}\left(\mathrm{H}_{2} \mathrm{O}\right)\right]^{+}$and $\left[\mathrm{Re}(\text { phen })(\mathrm{CO})_{3}\left(\mathrm{H}_{2} \mathrm{O}\right)\right]^{+}$

4.7. Cyclic Voltammetry Measurements of $\mathrm{Re}(\mathrm{L} \cap \mathrm{L})(\mathrm{CO})_{3} \mathrm{Cl}$ Complexes. ..................................... 4.8

4.8. Cyclic Voltammetry Measurements of $\left[\mathrm{Re}(\mathrm{L} \sim \mathrm{L})(\mathrm{CO})_{3}\left(\mathrm{H}_{2} \mathrm{O}\right)\right] \mathrm{Br}$ Complexes ............................. 4.9

4.9. Correlation of Emission Energy $\left(\mathrm{E}_{\mathrm{em}}\right)$ and Difference in Redox Potentials $\left(\Delta \mathrm{E}_{1 / 2}=\mathrm{E}_{1 / 2}\left(\operatorname{Re}^{\mathrm{II}} / \mathrm{Re}^{\mathrm{I}}\right)-\mathrm{E}_{1 / 2}\left(\mathrm{~L} / \mathrm{L}^{-}\right)\right.$for $\left.\mathrm{A}\right) \operatorname{Re}(\mathrm{L} \sim \mathrm{L})(\mathrm{CO})_{3} \mathrm{Cl}$, and B) $\left.\left[\mathrm{Re}(\mathrm{L} \cap \mathrm{L})(\mathrm{CO})_{3}\left(\mathrm{H}_{2} \mathrm{O}\right)\right] \mathrm{Br}\right)$...... 
4.10. Modulation of Luminescence Intensity of an Aqueous Solution of $5 \mathrm{mM}\left[\mathrm{Ru}(\mathrm{bpy})_{3}\right]^{2+}$ in 0.1 $\mathrm{M} \mathrm{KNO}_{3}$ with Time on the Application of Voltage $\left(\lambda_{\mathrm{ex}}=532 \mathrm{~nm}\right)$ and Nernst Plot of Log $[\mathrm{Ox}] /[\mathrm{Red}]$ vs. $\mathrm{E}_{\text {app }} \mathrm{vs} . \mathrm{Ag} / \mathrm{AgCl}$ at $620 \mathrm{~nm}$.

4.11. Modulation of $5 \mathrm{mM}\left[\mathrm{Ru}(\mathrm{bpy})_{3}\right]^{2+/ 3+}$ in $0.1 \mathrm{M} \mathrm{KNO}_{3}$ and Potential was Modulated Between $1.3 \mathrm{~V}$ and $0.8 \mathrm{~V}$ Where the Potential was Held for Five Minutes

4.12. Absorbance Modulation for $2 \mathrm{mM} \operatorname{Re}(\mathrm{dbbpy})(\mathrm{CO})_{3} \mathrm{Cl}$ and $0.1 \mathrm{M} \mathrm{TBACl}$ Solution in DMF.

4.13. Emission Modulation for $1.25 \mathrm{mM}\left[\mathrm{Re}(\mathrm{bpy})(\mathrm{CO})_{3}\left(\mathrm{H}_{2} \mathrm{O}\right)\right] \mathrm{Br}$ and $0.1 \mathrm{M} \mathrm{TBAPF}_{6}$ Solution in Acetonitrile.

4.14. Cyclic Voltammagrams of $1 \mathrm{mM}\left[\mathrm{Ru}(\mathrm{bpy})_{3}\right]^{2+}$ on Bare ITO Electrode; Uptake of $1 \mathrm{mM}$ $\left[\mathrm{Ru}(\mathrm{bpy})_{3}\right]^{2+}$ Into $70 \mathrm{~nm}$ Polymer SSEBS Film Coated on ITO; and Uptake of $1 \mathrm{mM}$ $\left[\mathrm{Ru}(\mathrm{bpy})_{3}\right]^{2+}$ Into $70 \mathrm{~nm}$ Polymer Nafion Film Coated on ITO.

4.15. Background Cyclic Voltammagrams Taken During 90-minute Equilibration in Solution Containing No Analyte Metal Onto a Bare ITO; $25 \mathrm{~nm}$ Polymer Nafion Film Coated on ITO; and $200 \mathrm{~nm}$ Polymer Nafion Film Coated on ITO

4.16. Cyclic Voltammagrams Taken During 90-minute Preconcentration of $10 \mu \mathrm{M}\left[\mathrm{Ru}(\mathrm{bpy})_{3}\right]^{2+}$ Onto a Bare ITO; $25 \mathrm{~nm}$ Polymer Nafion Film Coated on ITO; and $200 \mathrm{~nm}$ Polymer Nafion Film Coated on ITO.

4.17. Plot of Anodic and Cathodic Peak Currents From Cyclic Voltammagrams Taken During 90-minute Preconcentration of $10 \mu \mathrm{M}\left[\mathrm{Ru}(\mathrm{bpy})_{3}\right]^{2+}$ Onto $25 \mathrm{~nm}$ Polymer Nafion Film Coated on ITO and $200 \mathrm{~nm}$ Polymer Nafion Film Coated on ITO.

4.18. Cyclic Voltammagrams Taken During 90-minute Preconcentration of $1 \mathrm{mM}$ $\left[\mathrm{Re}(\right.$ dmeobpy $\left.)(\mathrm{CO})_{3}\left(\mathrm{H}_{2} \mathrm{O}\right)\right] \mathrm{Br}$ on a Bare ITO and a $70 \mathrm{~nm}$ Polymer Nafion Film Coated on ITO

4.19. Photograph of Prototype Sensor.

4.20. Schematic Diagram of Prototype Sensor.

4.21. Spectroelectrochemical Measurement Using $\left[\mathrm{Ru}(\mathrm{bpy})_{3}\right]^{2+}$ as Model Compound to Test System 



\subsection{Background}

The fate of technetium-99 $\left({ }^{99} \mathrm{Tc}\right)$, a Hanford Nuclear Reservation tank waste constituent, is a major River Protection Project (RPP) flowsheet uncertainty. The key driver to this flowsheet uncertainty is associated with the Integrated Disposal Facility (IDF) Performance Assessment ${ }^{99} \mathrm{Tc}$ risk determinations. Previous attempts to remove ${ }^{99} \mathrm{Tc}$ from the Hanford tank waste using an ion-exchange process specific to pertechnetate $\left(\mathrm{TcO}_{4}{ }^{-}\right.$, shown in Figure 1.1A) were only somewhat successful due to the presence of other valence and complexed forms of ${ }^{99} \mathrm{Tc}$ in some of the tank waste supernatants. In fiscal year 2013 (FY 2013), a study reviewed prior work as to the nature and extent of this non-pertechnetate, alkaline-soluble technetium in the Hanford waste tanks (Rapko et al. 2013). As noted in the 2013 report, prior work has tentatively identified a Tc(I)-carbonyl type compound as a non-pertechnetate species present in tank waste, the Tc(I)-tricarbonyl-tris-aquo compound $\left[\left(\mathrm{Tc}(\mathrm{CO})_{3}\left(\mathrm{H}_{2} \mathrm{O}\right)_{3}\right]^{+}\right.$; shown in Figure 1.1B.

There remain several significant uncertainties in the understanding and modeling of the fate and speciation of ${ }^{99} \mathrm{Tc}$ in Hanford waste tanks, glass, and low-temperature waste forms. A significant ( $2 \%$ to $25 \%$ ) fraction of the ${ }^{99} \mathrm{Tc}$ in the water-soluble portion of the tank waste may be present as a non-pertechnetate species that has not been identified and, based on experimentation to date, cannot be effectively separated from the wastes. This task will provide a sensor specifically tuned to detect the Tc(I)-carbonyl species believed to constitute the main fraction of the non-pertechnetate form of technetium. By direct measurement of the non-pertechnetate species, such a sensor will help reduce the uncertainties in the modeling of the fate and speciation of ${ }^{99} \mathrm{Tc}$ in Hanford tanks and waste forms.

The work covered in this report describes the research task undertaken to further the development of a sensor designed specifically to quantitatively measure the non-pertechnetate species within Hanford tank wastes. This task worked toward the goal of designing a sensor specific to the primary compound of interest, the Tc(I)-tri-carbonyl-tris-aquo compound $\left[\left(\mathrm{Tc}(\mathrm{CO})_{3}\left(\mathrm{H}_{2} \mathrm{O}\right)_{3}\right]^{+}\right.$.

The work scope covered in this report was supported by the U.S. Department of Energy's Office of Environmental Management (DOE-EM). This work was performed under Contract DE-AC05-76RL01830, in accordance with Test Plan TP-EMSP-0016, Rev. 0.0, and Test Plan TP-EMSP-0016, Rev. 1.0. Work was performed at the Pacific Northwest National Laboratory (PNNL) under Test Instruction TI-EMSP-0014, and at the University of Cincinnati (UC) under Test Instruction TI-EMSP-0016. The work described in this report was assigned the technology level "Applied Research." A portion of the testing did not comply with the quality requirements for Applied Research because some quality-affecting activities were performed before the Test Instructions were in place and prior to receiving authorization to proceed. However, PNNL believes that performing the work prior to receiving formal authorization to proceed had no detrimental impact on the quality of the research results. All staff members contributing to the work received proper technical and quality assurance training prior to performing quality-affecting work. 


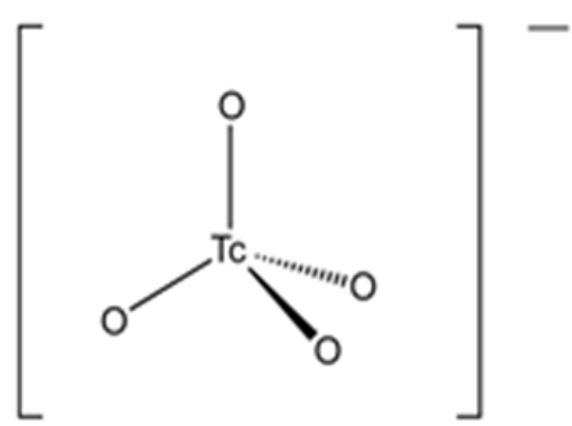

(A)

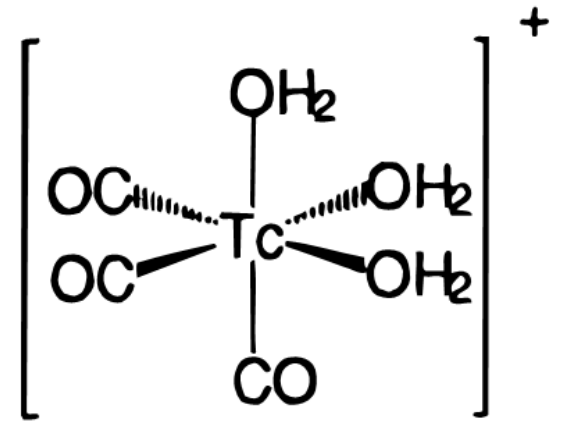

(B)

Figure 1.1. A) Structures of Pertechnetate, and B) Technetium(I) tri-carbonyl-tris-aquo Cation 


\subsection{Introduction}

The form of the non-pertechnetate Tc complex in some Hanford tank supernatants has been documented to be the $\left[\mathrm{Tc}(\mathrm{CO})_{3}\left(\mathrm{H}_{2} \mathrm{O}\right)_{3}\right]^{+}$or ligand-substituted complex $\left[\mathrm{Tc}(\mathrm{CO})_{3}(\mathrm{X})\left(\mathrm{H}_{2} \mathrm{O}\right)\right]^{+}$(where $\mathrm{X}$ is a multidentate ligand, such as glycolate, citrate, or oxalate) (Lukens et al. 2004). While the $\left[\mathrm{Tc}(\mathrm{CO})_{3}\left(\mathrm{H}_{2} \mathrm{O}\right)_{3}\right]^{+}$and related complexes are not readily detected optically, we proposed to convert $\left[\mathrm{Tc}(\mathrm{CO})_{3}\left(\mathrm{H}_{2} \mathrm{O}\right)_{3}\right]^{+}$into a fluorescent complex that would be detectable at the concentrations found in tank waste.

The direct reaction of $\left[\mathrm{Tc}(\mathrm{CO})_{3}\left(\mathrm{H}_{2} \mathrm{O}\right)_{3}\right]^{+}$or $\left[\mathrm{Tc}(\mathrm{CO})_{3}(\mathrm{X})\left(\mathrm{H}_{2} \mathrm{O}\right)\right]^{+}$with bidentate and tridentate ligands has been established under conditions (neutral and basic $\mathrm{pH}$, at room temperature, saline) suitable for radiotherapeutic applications(Alberto 2005; Alberto et al. 2001; Alberto et al. 1998). By changing the nature of the entering ligand groups to bipyridine (bpy), phenanthroline (phen), or functionalized bpy and phen ligands, we propose to convert the $\left[\mathrm{Tc}(\mathrm{CO})_{3}\left(\mathrm{H}_{2} \mathrm{O}\right)_{3}\right]^{+}$complex into optically emissive complexes with the formula $\left[\mathrm{Tc}(\mathrm{L} \sim \mathrm{L})(\mathrm{CO})_{3}\left(\mathrm{H}_{2} \mathrm{O}\right)\right]^{+}$according to the scheme shown below. The list of entering bidentate ligands ( $\mathrm{L} \cap \mathrm{L})$ includes: dtbbpy, dmbpy, dmebpy, bpy, dcbbpy, and phen.

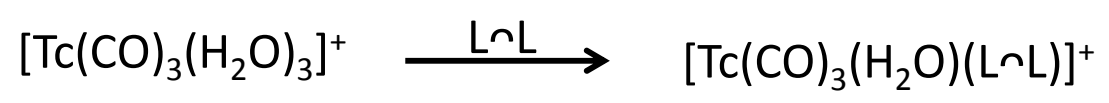

Along with $\mathrm{Tc}(\mathrm{I})$ complexes, we propose a range of $\operatorname{Re}(\mathrm{I})$ complexes, which have also previously been shown to be emissive (Richter et al. 1996). We are certain, based on our past work demonstrating the first documented examples of emissive technetium complexes (Chatterjee et al. 2011a; Chatterjee et al. 2013; Chatterjee et al. 2011b; Del Negro et al. 2006; Del Negro et al. 2005), that these related new $\mathrm{Tc}(\mathrm{I})$ complexes will show fluorescent properties as well.

In our past work under separate funding sources and in collaboration with the University of Cincinnati, we have developed and demonstrated a selective optical sensor for the luminescent $\mathrm{Tc}$ (II) complex $\left[\mathrm{Tc}(\mathrm{dmpe})_{3}\right]^{2+}$, which is composed of a selective polymer film that preconcentrates the Tc complex within the spectroelectrochemical compartment of the sensor. After the Tc complex is absorbed into the polymer film, the cell is activated electrochemically and the $\left[\mathrm{Tc}(\mathrm{dmpe})_{3}\right]^{2+}$ complex is modulated between the Tc(I) (non-emissive) and the Tc(II) (emissive) redox states. The recorded luminescent emission was demonstrated to be proportional to Tc concentration, linear over 5-6 orders of magnitude in concentration, and with a detection limit at the nanomolar level (Chatterjee et al. 2011a).

This task seeks to convert the non-emissive $\left[\mathrm{Tc}(\mathrm{CO})_{3}\left(\mathrm{H}_{2} \mathrm{O}\right)_{3}\right]^{+}$complexes into the emissive $\left[\mathrm{Tc}(\mathrm{L} \sim \mathrm{L})(\mathrm{CO})_{3}\left(\mathrm{H}_{2} \mathrm{O}\right)\right]^{+}$complex, followed by the fluorescence mode detection of these new species within a polymer-film-based sensor. This report details the experimental work performed during FY 2014 to accomplish these goals.

\subsection{Concept for Detection of Non-pertechnetate Form of Technetium}

The general strategy for the selective detection of $\left[\mathrm{Tc}(\mathrm{CO})_{3}\left(\mathrm{H}_{2} \mathrm{O}\right)_{3}\right]^{+}$in solution is the conversion of the complex into a fluorescent form, followed by the optical measurement of the emission signal. To achieve desired detection limits, fluorescent molecules are needed which can reasonably reach 
sub-nanomolar concentrations. For several reasons, to achieve required selectivity, reversible electrochemistry is also needed to 1) change the Tc oxidation state to create/quench fluorescence; 2) allow modulated electrochemical-induced fluorescence (on/off) signal; and 3) modulate (change) the signal of Tc to distinguish it from the constant fluorescence from interfering species.

The general steps for making a sensor based on this concept are shown in Figure 2.1; they are 1) formation of a technetium ligand complex prior to introduction into the sensor; 2) technetium uptake into a chemically-selective film; 3) optical detection of $\mathrm{Tc}(\mathrm{L} \sim \mathrm{L})$; and 4) electrochemical modulation.

Various aspects of the sensor development were worked on within this task. Section 3.0 of this report contains details of the experimental work. The various steps shown in Figure 2.1 are being independently developed and optimized prior to the final sensor concept demonstration. Section 4.1 discusses the formation of fluorescent Tc complexes and their rhenium analogs; Section 4.2 provides details of the electrochemistry; Section 4.3 provides details of the spectroelectrochemical measurements of the Re-carbonyl complexes. Section 4.4 gives details of the selective partitioning of $\operatorname{Re}(\mathrm{I})$-carbonyl and other model complexes into ion-selective films.
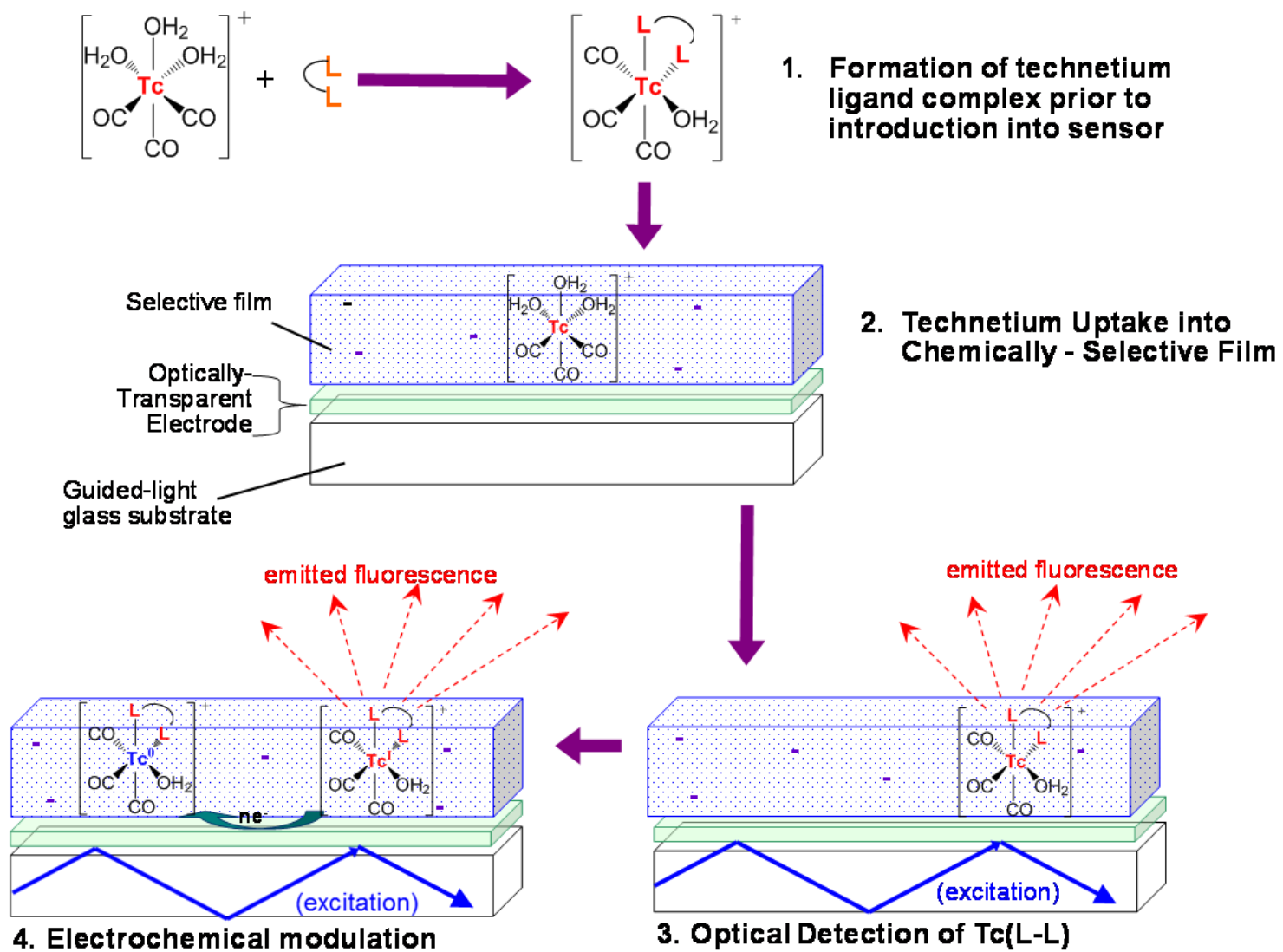

Figure 2.1. Concept for Detection of Non-pertechnetate Form of Technetium 


\subsection{Experimental}

The methodology for the detection of a Tc complex centers around the formation of a fluorescent $\mathrm{Tc}(\mathrm{I})$ complex with the general formula $\left[\mathrm{Tc}(\mathrm{L} \sim \mathrm{L})(\mathrm{CO})_{3}\left(\mathrm{H}_{2} \mathrm{O}\right)\right]^{+}$from the non-emissive $\left[\mathrm{Tc}(\mathrm{CO})_{3}\left(\mathrm{H}_{2} \mathrm{O}\right)_{3}\right]^{+}$ complex. Re(I) analogs to the Tc system are used in testing the methodology of the sensor concept. The Tc-carbonyl and Re-carbonyl complexes targeted are also electroactive, which leads to their specific detection by using the spectroelectrochemical technique. This section of the report describes the general system development and testing performed to provide a basis for later sensor measurements.

\subsection{Preparation of Complexes}

The general strategy for the synthesis of rhenium-carbonyl complexes of the general formula $\left[\mathrm{Re}(\mathrm{L} \sim \mathrm{L})(\mathrm{CO})_{3}\left(\mathrm{H}_{2} \mathrm{O}\right)\right] \mathrm{Br}$ is shown in Figure 3.1. As shown in this figure, a convenient starting material is $\operatorname{Re}_{2}(\mathrm{CO})_{10}$, which can be reacted with elemental bromine to form the $\operatorname{Re}(\mathrm{I})$ complex $\operatorname{Re}(\mathrm{CO})_{5} \mathrm{Br}$. Reaction of $\operatorname{Re}(\mathrm{CO})_{5} \mathrm{Br}$ with water under reflux conditions forms the bromide salt of the $\operatorname{Re}(\mathrm{I})$-aquo complex, $\left[\operatorname{Re}(\mathrm{CO})_{3}\left(\mathrm{H}_{2} \mathrm{O}\right)_{3}\right]^{+}$, which can be reacted with a bidentate ligand (such as bpy or phen) forming the final product $\left[\operatorname{Re}(\mathrm{L} \sim \mathrm{L})(\mathrm{CO})_{3}\left(\mathrm{H}_{2} \mathrm{O}\right)\right]^{+}$, shown in the bottom right of Figure 3.1. Synthesis of the $\left[\mathrm{Tc}(\mathrm{bpy})(\mathrm{CO})_{3}\left(\mathrm{H}_{2} \mathrm{O}\right)\right]^{+}$and $\left[\mathrm{Tc}(\mathrm{phen})(\mathrm{CO})_{3}\left(\mathrm{H}_{2} \mathrm{O}\right)\right]^{+}$complexes is shown in Figure 3.2. In general the entering ligand can be a variety as given in Figure 3.3. The following paragraphs in this section give details of the preparation of each of the complexes used in this study.

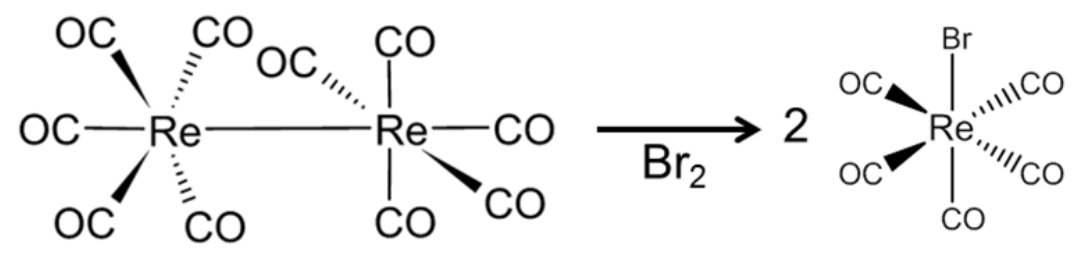

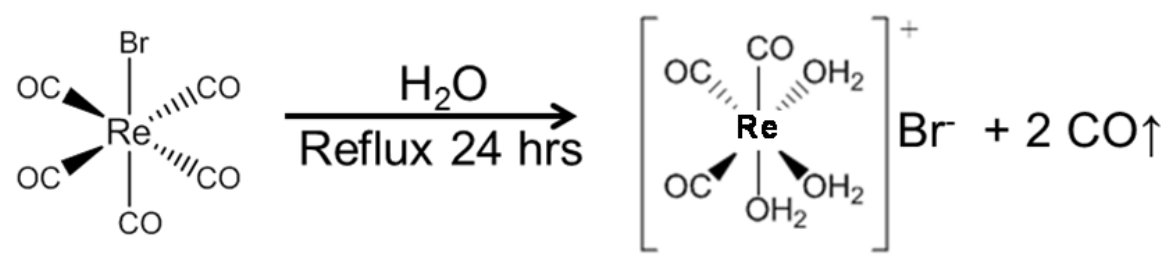

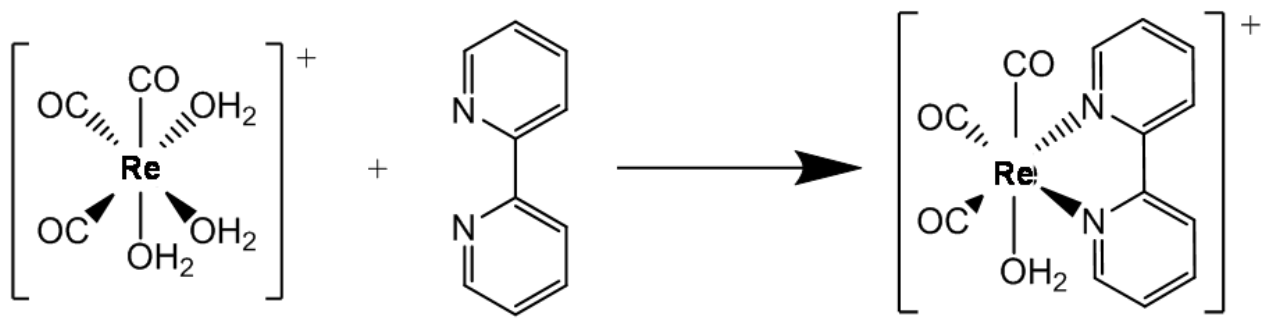

Figure 3.1. General Synthesis for $\left[\operatorname{Re}(\mathrm{L} \cap \mathrm{L})(\mathrm{CO})_{3}\left(\mathrm{H}_{2} \mathrm{O}\right)\right] \mathrm{Br}$. A list of ligands $(\mathrm{L} \cap \mathrm{L})$ used in this work is given in Figure 3.3. 

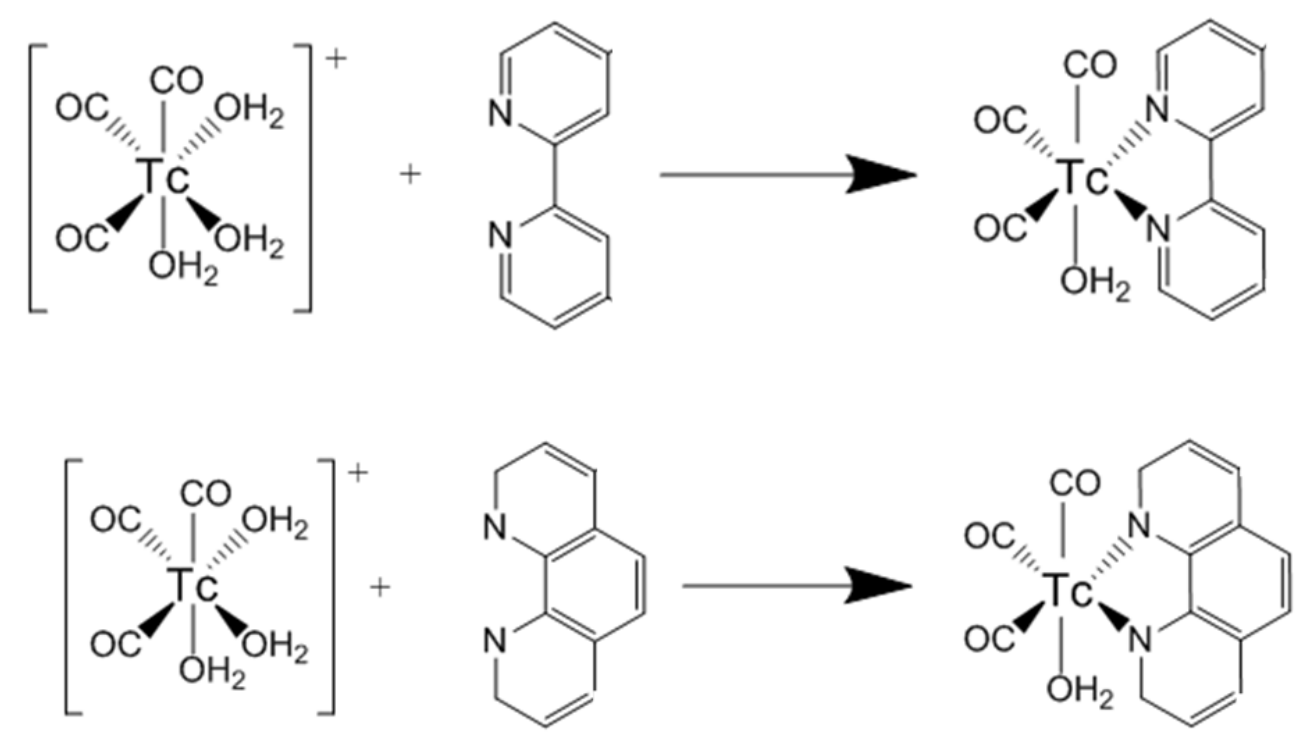

Figure 3.2. Synthesis for $\left[\mathrm{Tc}(\mathrm{bpy})(\mathrm{CO})_{3}\left(\mathrm{H}_{2} \mathrm{O}\right)\right]^{+}$(top) or $\left[\mathrm{Tc}(\text { phen })(\mathrm{CO})_{3}\left(\mathrm{H}_{2} \mathrm{O}\right)\right]^{+}$(bottom) Complexes. In general the entering ligand can be a variety as given in Figure 3.3. 


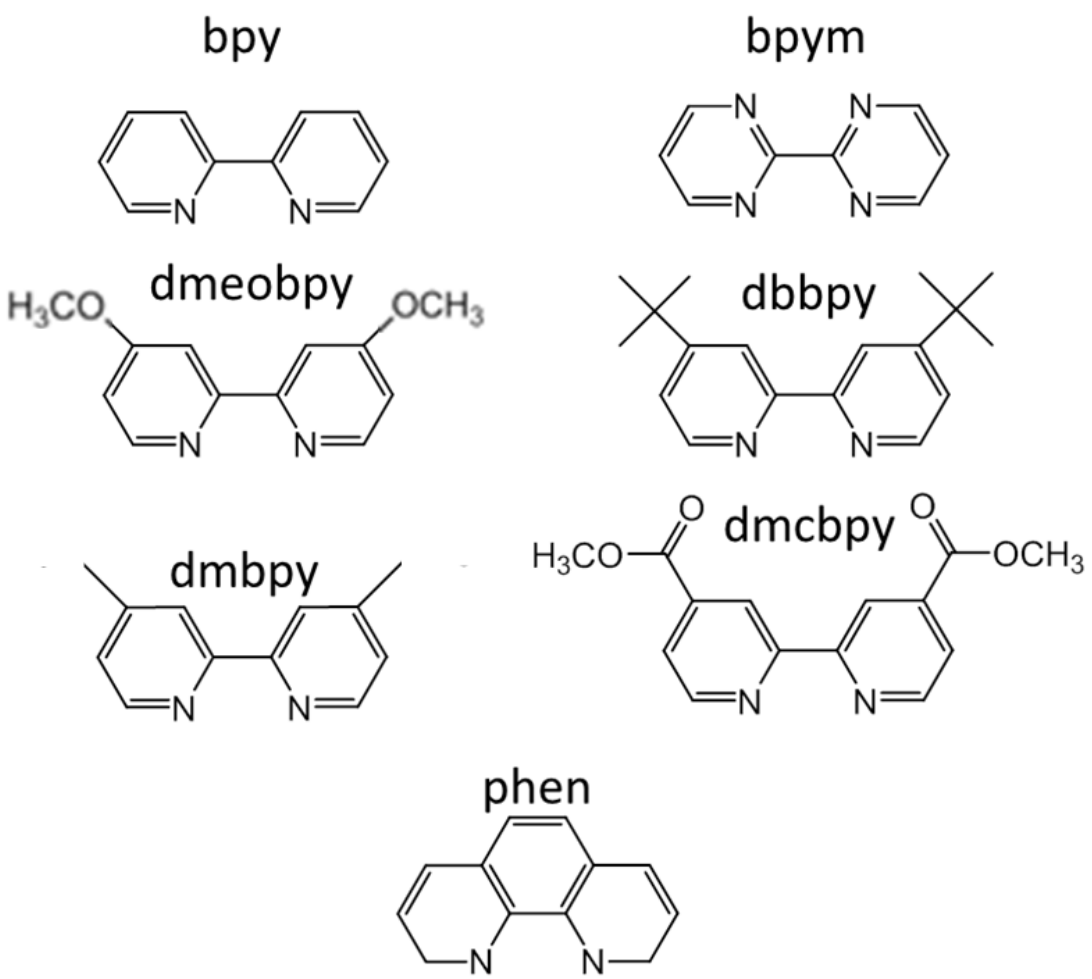

Figure 3.3. List of Ligands Used for the Preparation of $\left[\mathrm{Re}(\mathrm{L} \cap \mathrm{L})(\mathrm{CO})_{3}\left(\mathrm{H}_{2} \mathrm{O}\right)\right]^{+}$or $\left[\mathrm{Tc}(\mathrm{L} \cap \mathrm{L})(\mathrm{CO})_{3}\left(\mathrm{H}_{2} \mathrm{O}\right)\right]^{+}$Complexes. The list includes 2,2'-bipyridine (bpy); 2,2'-bipyrimidine (bpym); 4,4'-Dimethoxy-2,2'-bpy (dmeobpy); 4,4'-di-tert-butyl-2,2'-bpy (dbbpy); 4,4'-dimethyl-bpy (dmbpy); 4,4'-dimethylcarboy-2,2'-bpy (dmcbpy); and 1,10-phenanthroline (phen).

Chemicals and Materials. The following chemicals and solvents were obtained from Sigma-Aldrich (unless otherwise indicated) and used without further purification: toluene (anhydrous, 99.8\%); dichloromethane (anhydrous, 99.8\%); diethyl ether (anhydrous, 99.0\%); tetrahydrofuran; acetonitrile; tetra-n-butylammonium hexafluoraphosphate $\left(\mathrm{TBAPF}_{6}\right) ; 2,2^{\prime}$-bipyridyl $(99 \%)$; 4,4'-dimethyl2,2'-dipyridyl (99.5\%); 4-4'-dimethoxy-2-2'-bipyridine (97\%); 4-4-di-tert-butyl-2-2'-bipyridine (98\%); 4,4'-dimethylcarboxy-2,2'-bipyridine (98\%); 1,10 phenanthroline (99\%); $5 \mathrm{wt} \%$ polystyrene-block-poly(ethylene-ran-butylene)-block-polystyrene, sulfonated solution in 1-propanol and dichloroethane; $5 \mathrm{wt} \%$ Nafion solution in lower aliphatic alcohols and water; 1,2-dichloroethane (Fisher). The optically transparent electrodes were $10 \mathrm{~mm} \times 40 \mathrm{~mm}$ indium tin oxide (ITO) coated on glass ( $20 \Omega /$ sq., 150 nm ITO layer on 1737F glass; Thin Film Devices, Anaheim, California). Aqueous solutions were prepared with deionized water (D2798 Nanopure system; Barnstead, Boston, MA). The $\mathrm{NH}_{4}{ }^{99} \mathrm{TcO}_{4}$ solid is from the PNNL stock supply.

$\operatorname{Re}(\mathbf{C O})_{5} \mathbf{B r}$. Approximately $7 \mathrm{mmol} \mathrm{Re}_{2}(\mathrm{CO})_{10}$ was added to a round bottom flask, to which $50 \mathrm{~mL}$ of dichloromethane was added. The solution was stirred to ensure all starting material was dissolved. In

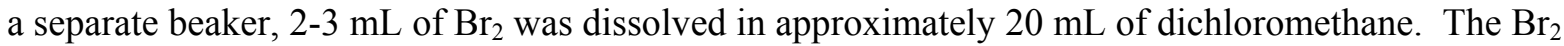
solution was added, drop-wise, to the flask containing the $\mathrm{Re}_{2}(\mathrm{CO})_{10}$ until the light brown/orange color persisted. The solution was allowed to stir for 5 minutes to ensure the color remained. The solvent was 
removed using rotary evaporation. The product remaining was a fine, white powder, usable as-is without further purification. A similar method was mentioned in previous articles (Angelici and Kruse 1970; Schmidt et al. 1990).

$\left[\operatorname{Re}(\mathbf{C O})_{3}\left(\mathbf{H}_{2} \mathbf{O}\right)_{3}\right]$ Br. Approximately $1.2 \mathrm{mmol} \operatorname{Re}(\mathrm{CO})_{5} \mathrm{Br}$ was added to a round bottom flask, to which $20 \mathrm{~mL}$ of DI water was added. The starting material did not dissolve in room temperature water. The solution was allowed to reflux for at least 24 hours at $100{ }^{\circ} \mathrm{C}$. Periodically, the condenser needed rinsing due to the starting material getting deposited at the bottom of the condenser. Upon completion of the reflux, the solvent was removed using rotary evaporation. The product was dried and stored for use (Haiyang et al. 2005; Lazarova et al. 2004; Salignac et al. 2003).

General $\left[\operatorname{Re}(\mathbf{L} \mathbf{\circ})(\mathbf{C O})_{3}\left(\mathrm{H}_{2} \mathrm{O}\right)\right] \mathbf{B r}$ Synthesis. Approximately $1 \mathrm{mmol} \operatorname{Re}(\mathrm{CO})_{3}\left(\mathrm{H}_{2} \mathrm{O}\right)_{3} \mathrm{Br}$ was added to a round bottom flask, to which $40 \mathrm{~mL}$ of dichloromethane was added. The temperature controller was turned on to begin heating the solution. More solvent was added, as necessary, to ensure all of the $\mathrm{Re}(\mathrm{CO})_{3}\left(\mathrm{H}_{2} \mathrm{O}\right)_{3} \mathrm{Br}$ was dissolved before the ligand addition. Approximately $1.1 \mathrm{mmol}$ of the ligand (bpy, dmbpy, dbbpy, dmeobpy, dmcbpy, bpym, or phen) was added to the flask. Immediately upon ligand addition a color change was observed. The solution was allowed to reflux for approximately 5 hours at $40{ }^{\circ} \mathrm{C}$. The solution was then allowed to cool back to room temperature. If no precipitate was observed, then the solvent was removed using rotary evaporation. If precipitate was observed, then the sample was filtered and rinsed with diethyl ether. The product was dried and stored for use. The percent yield for all reactions ranged from $71 \%$ (for $\left[\mathrm{Re}(\mathrm{phen})(\mathrm{CO})_{3}\left(\mathrm{H}_{2} \mathrm{O}\right)\right] \mathrm{Br}$ ) to $92 \%$ (for $\left.\left[\mathrm{Re}(\mathrm{dbbpy})(\mathrm{CO})_{3}\left(\mathrm{H}_{2} \mathrm{O}\right)\right] \mathrm{Br}\right)$, compared to the theoretical yield.

General $\operatorname{Re}(\mathbf{L} \sim \mathbf{L})(\mathbf{C O})_{3} \mathbf{C l}$ Synthesis. Complexes of the general formula $\operatorname{Re}(\mathrm{CO})_{3}(\mathrm{~L} \cap \mathrm{L}) \mathrm{Cl}$, where $\mathrm{L} \sim \mathrm{L}=$ bpy , dtbbpy, dmbpy, dmeobpy, and dcbpy (bpy = 2,2'-bipyridine; dtbbpy $=4,4$ '-di-tert-butyl2,2'-bipyridine; dmbpy = 4,4'-dimethyl-2,2'-bipyridine; dmeobpy = 4,4'-dimethoxy-2,2'-bipyridine; dcbpy $=4,4^{\prime}$-dicarbomethoxy-2,2'-bipyridine), were prepared using the reported method (Smieja and Kubiak 2010). The percent yield for the reactions ranged from $76 \%$ to $91 \%$ (compared to the theoretical yield) for all products except for $\operatorname{Re}(\mathrm{CO})_{3}($ dmebpy $) \mathrm{Cl}$, which had a yield of $52 \%$.

$\left(\mathbf{E t}_{4} \mathbf{N}\right)_{2}\left[\mathbf{T c}(\mathbf{C O})_{3} \mathbf{C l}_{3}\right]$. The starting material, $\left(\mathrm{Et}_{4} \mathrm{~N}\right)_{2}\left[\mathrm{Tc}(\mathrm{CO})_{3} \mathrm{Cl}_{3}\right]$, was synthesized from $\mathrm{NH}_{4} \mathrm{TcO}_{4}$ following the procedure as described previously (Kurz et al. 2006). This complex was the starting material used for preparation of $\left[\mathrm{Tc}(\mathrm{CO})_{3}(\mathrm{bpy})\left(\mathrm{H}_{2} \mathrm{O}\right)\right]^{+}$and $\left[\mathrm{Tc}(\mathrm{CO})_{3}(\mathrm{phen})\left(\mathrm{H}_{2} \mathrm{O}\right)\right]^{+}$complexes (phen $=1,10$-phenanthroline).

$\left[\mathbf{T c}(\mathbf{b p y})(\mathbf{C O})_{3}\left(\mathrm{H}_{2} \mathbf{O}\right)\right]^{+}$. Approximately $10 \mathrm{mg}$ of $\left(\mathrm{Et}_{4} \mathrm{~N}\right)_{2}\left[\mathrm{Tc}(\mathrm{CO})_{3} \mathrm{Cl}_{3}\right]$ was dissolved in $2 \mathrm{~mL} \mathrm{H}_{2} \mathrm{O}$. This solution was stirred for 20 minutes before adding $1.5 \mathrm{~mL}$ of a $2: 1 \mathrm{H}_{2} \mathrm{O}: \mathrm{EtOH}$ solution with $5.38 \mathrm{mg}$ (34 mM) of dissolved bpy. After about 2 hours, an additional $1 \mathrm{~mL}$ of a 2:1 $\mathrm{H}_{2} \mathrm{O}:$ EtOH solution with $2.93 \mathrm{mg}(19 \mathrm{mM})$ of dissolved bpy was added. This resulted in an approximately 3:1 molar ratio between the ligand and metal complex. After several hours the solution had a yellow color. The solution was stirred overnight. The yield for this reaction was not estimated. Samples of the reaction solution containing $\left[\mathrm{Tc}(\mathrm{CO})_{3}(\text { bpy })\left(\mathrm{H}_{2} \mathrm{O}\right)\right]^{+}$were taken for spectroscopic measurements and are discussed in Section 4.1.

[Tc(phen) $\left.(\mathbf{C O})_{3}\left(\mathrm{H}_{2} \mathbf{O}\right)\right]^{+}$. Approximately $10 \mathrm{mg}$ of synthesized $\left(\mathrm{Et}_{4} \mathrm{~N}\right)_{2}\left[\mathrm{Tc}(\mathrm{CO})_{3} \mathrm{Cl}_{3}\right]$ was dissolved in $2 \mathrm{~mL} \mathrm{H}_{2} \mathrm{O}$. This solution was stirred for 20 minutes before adding $1 \mathrm{~mL}$ of a $2: 1 \mathrm{H}_{2} \mathrm{O}$ :EtOH solution with $12.07 \mathrm{mg}(67 \mathrm{mM})$ of dissolved phen. This addition resulted in a 3:1 ratio between the ligand and 
metal complex. The solution was stirred overnight and appeared to be a yellowish suspension the following morning. The yield for this reaction was not estimated. Samples of the reaction solution containing $\left[\mathrm{Tc}(\mathrm{CO})_{3}(\text { phen }) \mathrm{H}_{2} \mathrm{O}\right]^{+}$were taken for spectroscopic measurements and are discussed in Section 4.1.

The preparation of the Re analog complexes $\left(\left[\operatorname{Re}(\mathrm{L} \sim \mathrm{L})(\mathrm{CO})_{3}\left(\mathrm{H}_{2} \mathrm{O}\right)\right] \mathrm{Br}\right)$ was optimized for producing pure complexes to be used in electrochemistry and spectroscopy experiments. For this, we used a near-stoichiometric ratio of reagents. When we move to testing the protocol for producing the fluorescent Tc complex in-situ, we will use excess of sensitizing ligand. The amount of excess ligand to be used will be determined when the protocol is examined.

\subsection{Electrochemistry, Spectroscopy, and Spectroelectrochemistry}

Electrochemistry. Electrochemical measurements were carried out using a Princeton Applied Research 273A (EG\&G) potentiostat with Corrware software v3.3b from Scribner Associates or an Epsilon Potentiostat (Bioanalytical Systems, Inc.(BASi)) using BASi software. A standard three-electrode setup was used with a Pt wire reference electrode, Pt disc working electrode, and Pt wire auxiliary electrode (BASi). Solutions used for cyclic voltammetric experiments used $5 \mathrm{mM}$ rhenium complex concentration. All electrochemical experiments were performed in acetonitrile $(\mathrm{MeCN})$ containing $0.1 \mathrm{M}$ tetra-n-butylammonium hexafluoraphosphate $\left(\mathrm{TBAPF}_{6}\right)$. All electrochemical experiments were purged with $\mathrm{N}_{2}$ for several minutes and then blanketed with $\mathrm{N}_{2}$ during the experiments.

Solution Absorption and Emission Spectroscopy. UV-visible absorbance measurements were completed using a Varian Cary UV-Visible 50 Bio spectrometer in $1 \mathrm{~cm}$ cuvettes. Solutions used for absorbance experiments generally used $0.05 \mathrm{mM}$ rhenium complex concentration. Emission spectra were recorded using a Horiba Jobin Yvon Fluorolog III fluorimeter equipped with a $450 \mathrm{~W}$ xenon lamp, double-emission monochromator blazed at $500 \mathrm{~nm}$, and a single-excitation monochromator blazed at $300 \mathrm{~nm}$. Emission spectra were corrected for instrumental response.

Cryogenic Laser Fluorescence Spectroscopy. The instrumentation and experimental procedures for fluorescence spectroscopic measurements at liquid helium temperature were described previously (Wang et al. 2005a; Wang et al. 2005b). The quartz sample cuvettes were attached to the cold finger of a CRYO Industries RC152 cryostat with liquid helium vaporizing beneath the sample to reach a sample temperature of $8 \pm 2 \mathrm{~K}$. The sample was excited with a Spectra-Physics Nd:YAG laser pumped Lasertechnik-GWU MOPO laser at $415 \mathrm{~nm}$ and the emitted light was collected at $85^{\circ}$ to the excitation beam and detected with a thermoelectrically cooled Princeton Instruments PIMAX intensified CCD camera after spectral dispersion through an Acton SpectroPro 300i double monochromator spectrograph using Acton data acquisition software.

Spectroelectrochemistry. Spectroelectrochemical (SEC) experiments were performed using a PAR 273A potentiostat. A standard three-electrode thin cell setup was used with a Pt wire reference electrode, $1 \mathrm{~mm}$ Pt mesh working electrode, and approximately $2 \mathrm{~mm}$ Pt mesh auxiliary electrode. The BASi thin-layer cell used is a quartz cuvette with a $1 \mathrm{~mm}$ path length. Solutions used for SEC experiments were generally $\sim 1 \mathrm{mM}$ rhenium complex concentration. The optical components include a $405 \mathrm{~nm}$ laser from Power Technology Incorporated or a $532 \mathrm{~nm}$ laser excitation source (Melles Griot, $20 \mathrm{~mW} \mathrm{CW}$ ), coupled with an InSpectrum 150 spectrometer-CCD, and using SpectraSense data acquisition software. 
Signal integration times were typically $999 \mathrm{~ms}$ using a 2-mm slit width for a 600 -grooves-per-mm grating blazed at $500 \mathrm{~nm}$. A $532 \mathrm{~nm}$ holographic notch filter (Kaiser) was used when using the $532 \mathrm{~nm}$ laser source to reduce laser light backscattered into the InSpectrum 150 spectrometer.

For absorption mode spectroelectrochemical measurements under absorption mode, a BASi thin layer $(1 \mathrm{mM})$ absorbance cell was used as shown in Figure 3.4. For emission measurements, a $90^{\circ}$ scattering fiber-optic probe was used for collection of emission measurements. A photograph of the spectroelectrochemical cell showing the placement of the platinum electrode is shown in Figure 3.5A. Figure $3.5 \mathrm{~B}$ is a photograph of an overhead view of the cuvette showing the $\operatorname{Re}(\mathrm{bpy})(\mathrm{CO})_{3}\left(\mathrm{H}_{2} \mathrm{O}\right)^{+}$ complex in solution luminescing under $415 \mathrm{~nm}$ excitation. Figure $3.5 \mathrm{C}$ is an oblique view showing the cuvette in the holder with optical fibers attached for absorbance mode detection. The apparatus for performing spectroelectrochemical measurements is shown in Figure 3.6A indicating the location of the electrochemical potentiostat adjacent to the optical components shown in Figure 3.6B.

\section{Front view}

\section{Side view}
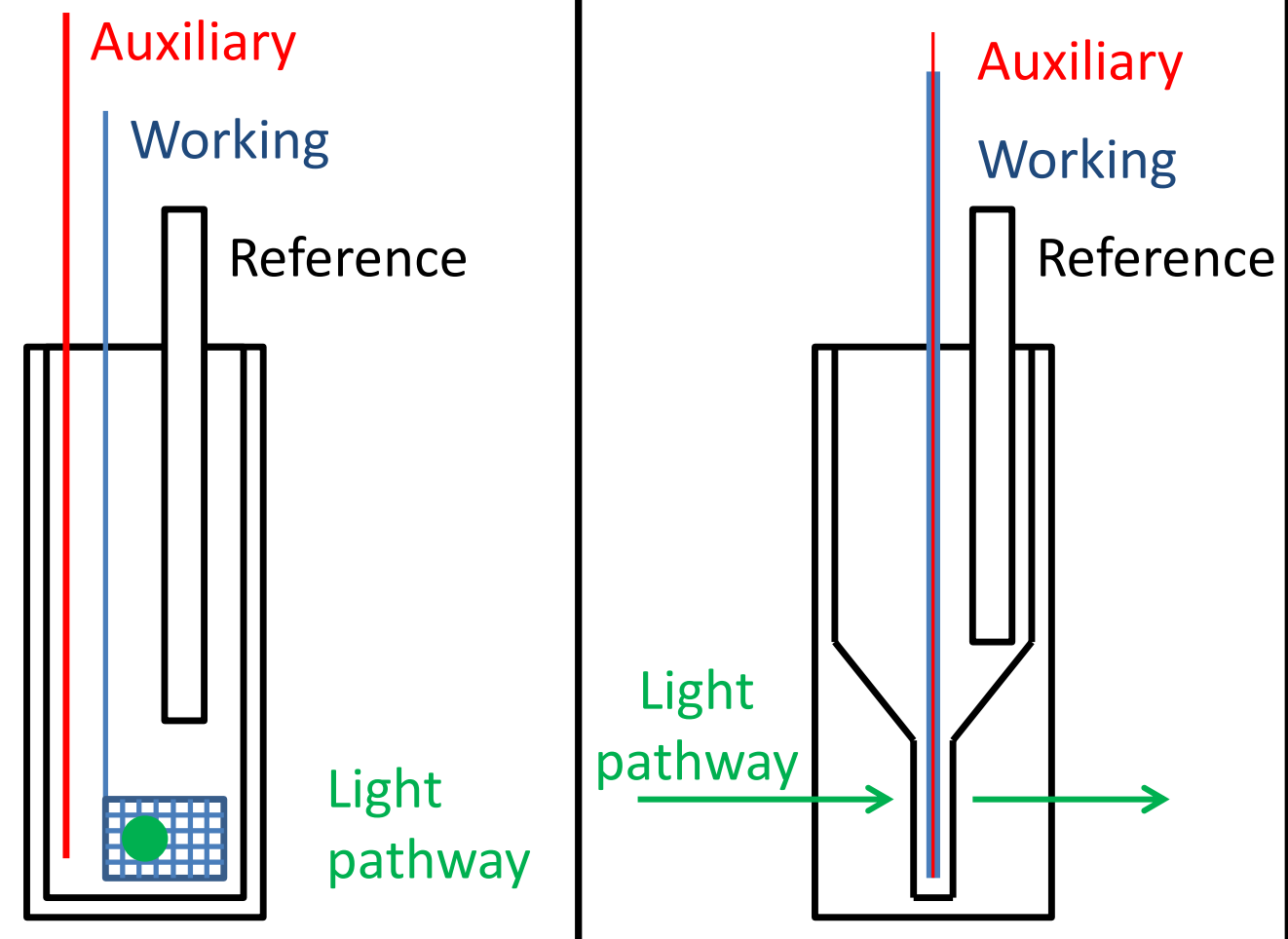

Figure 3.4. Schematic of Absorbance-based Spectroelectrochemical Cell Showing (A) Front View and (B) Side View with Optical Path 

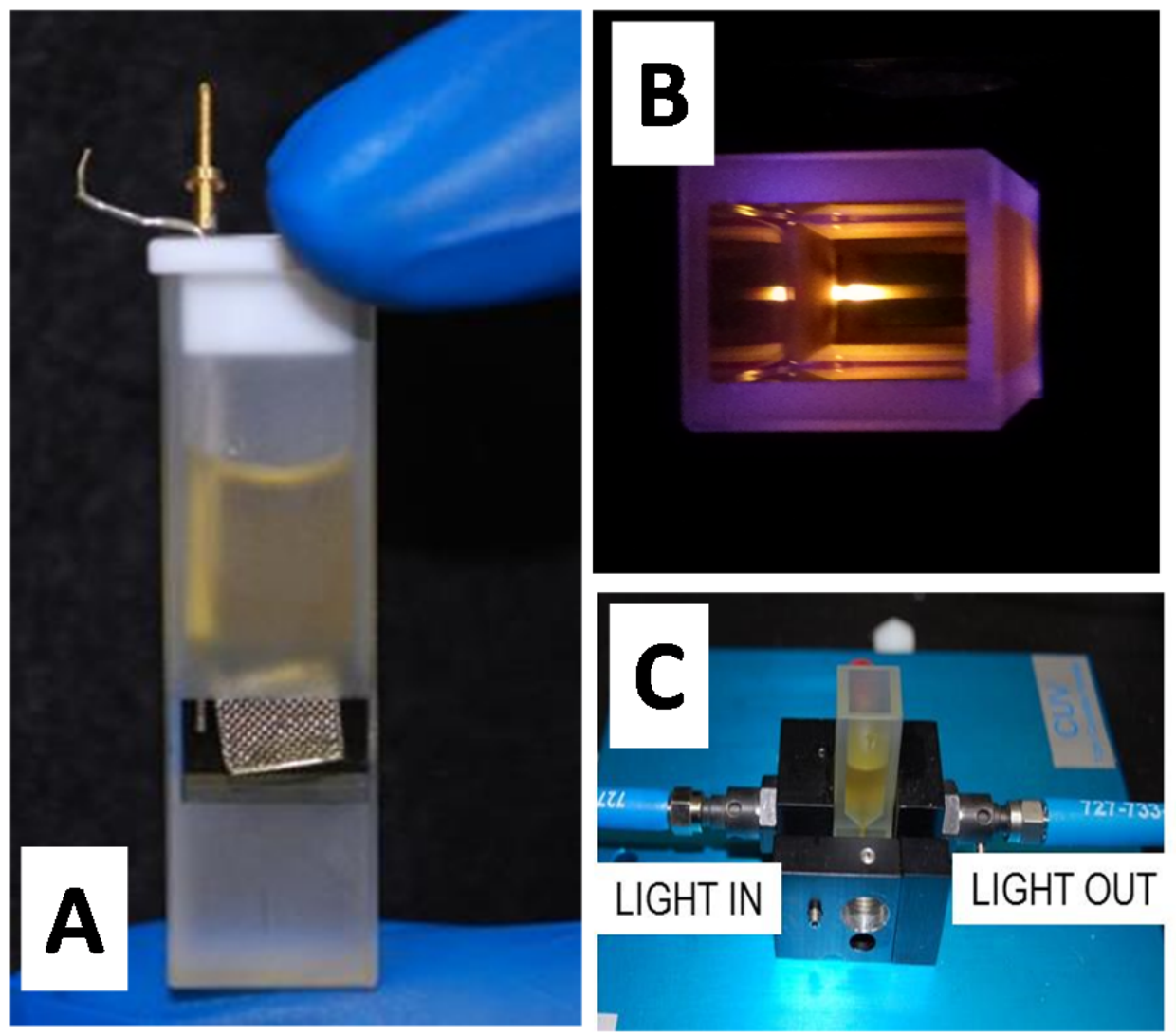

Figure 3.5. Photographs of Spectroelectrochemical Cell Showing (A) Front View with Platinum Electrode Placed in Optical Path, (B) Overhead View of Cuvette Showing $\mathrm{Re}(\mathrm{bpy})(\mathrm{CO})_{3}\left(\mathrm{H}_{2} \mathrm{O}\right)^{+}$Complex in Solution Luminescing, and (C) Oblique View Showing Cuvette in Holder with Optical Fibers Attached for Absorbance Mode Detection
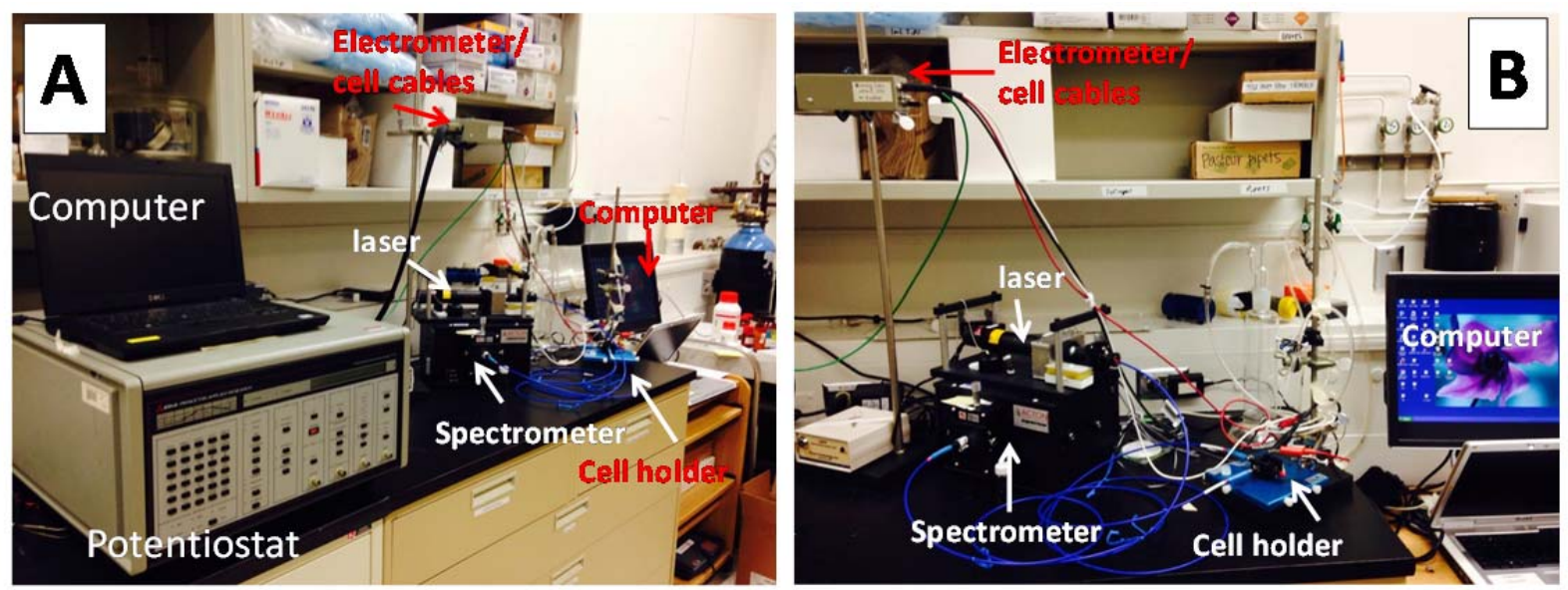

Figure 3.6. Apparatus for Performing Spectroelectrochemical Measurements Showing the Location of the (A) Electrochemical Potentiostat Adjacent to the Optical Components; and (B) Including Spectrometer and Cell Holder 



\subsection{Sensor Development: Results and Discussion}

Section 4.1 discusses the fluorescence and absorption measurement of Tc-carbonyl complexes and their rhenium analogs; Section 4.2 provides details of the electrochemistry of the Re-carbonyl complexes; Section 4.3 gives details of the absorption mode and fluorescence emission mode spectroelectrochemistry measurements of the Re-carbonyl complexes; and Section 4.4 is a summary of the selective partitioning of Re-carbonyl and other model complexes into ion-selective films.

\subsection{Optical Measurements of Tc and Re Complexes}

To achieve the desired detection limits, fluorescent molecules are needed because fluorescence detection methods are many orders of magnitude more sensitive than other optical techniques. The fluorescence measurement of $\left[\mathrm{Tc}(\mathrm{bpy})(\mathrm{CO})_{3}\left(\mathrm{H}_{2} \mathrm{O}\right)\right]^{+}$and $\left[\mathrm{Tc}(\mathrm{phen})(\mathrm{CO})_{3}\left(\mathrm{H}_{2} \mathrm{O}\right)\right]^{+}$was performed, along with Re analog complexes, which demonstrates the ability to use these molecules as target analytes within the proposed fluorescence-based spectroelectrochemical sensor.

Optical measurements of $\operatorname{Re}(\mathbf{L} \boldsymbol{\wedge} \mathbf{L})(\mathbf{C O})_{3} \mathbf{C l}$. The excitation and emission measurements of $\operatorname{Re}(\mathrm{L} \sim \mathrm{L})(\mathrm{CO})_{3} \mathrm{Cl}$ complexes in acetonitrile solution, where $\mathrm{L} \sim \mathrm{L}=2,2^{\prime}$-bipyridine (bpy);

4,4'-di-tert-butyl-2,2'-bpy (dbbpy); 4,4'-dimethoxy-2,2'-bpy (dmeobpy); 4,4'-dimethyl-bpy (dmbpy); 1,10-phenanthroline (phen); and 2,2'-bipyrimidine (bpym), are shown in Figure 4.1. This series of Re-carbonyl complexes was prepared, and optical properties measured, for comparison to known literature complexes of the same formula. These Re-chloro-carbonyl complexes are also a route for preparing the Re-aquo-carbonyl complexes of interest to this work.

From Figure 4.1A, the excitation spectra show a large intensity band at $\sim 325 \mathrm{~nm}$, and multiple large intensity bands from $\sim 400 \mathrm{~nm}$ to $475 \mathrm{~nm}$. Based on the excitation spectra we selected the $415 \mathrm{~nm}$ excitation band and measured the emission spectra as taken and shown in Figure 4.1B. The emission spectra for the various $\mathrm{Re}(\mathrm{L} \sim \mathrm{L})(\mathrm{CO})_{3} \mathrm{Cl}$ complexes show a maximum between $590-620 \mathrm{~nm}$, each varying depending on choice of bound bidentate ligand group used; $\mathrm{L} \sim \mathrm{L}=\mathrm{bpy}$, dbbpy, dmeobpy, dmbpy, or phen.

Optical measurements of $\left[\operatorname{Re}(\mathrm{L} \sim \mathrm{L})(\mathrm{CO})_{3}\left(\mathrm{H}_{2} \mathrm{O}\right)\right] \mathrm{Br}$. The absorption spectra of $\operatorname{six}\left[\operatorname{Re}(\mathrm{L} \sim \mathrm{L})(\mathrm{CO})_{3}\left(\mathrm{H}_{2} \mathrm{O}\right)\right] \mathrm{Br}$ complexes in acetonitrile solution, where $\mathrm{L} \cap \mathrm{L}=2,2^{\prime}$-bipyridine (bpy); 4,4'-di-tert-butyl-2,2'-bpy (dbbpy); 4,4'-dimethoxy-2,2'-bpy (dmeobpy); 4,4'-dimethyl-bpy (dmbpy); 1,10-phenanthroline (phen); and 2,2'-bipyrimidine (bpym), and the model $\mathrm{Ru}(\mathrm{bpy})_{2} \mathrm{Cl}_{2}$ complex are shown in Figure 4.2. The excitation spectra of the complexes are shown in Figure 4.3. With the exception of the phen complex, all the complexes showed maxima in the excitation spectra between $400 \mathrm{~nm}$ and $500 \mathrm{~nm}$, with the maximum at approximately $450 \mathrm{~nm}$. Based on the absorption spectra in Figure 4.3 we selected the $450 \mathrm{~nm}$ excitation wavelength for measuring the emission spectra for the six $\left[\operatorname{Re}(\mathrm{L} \sim \mathrm{L})(\mathrm{CO})_{3}\left(\mathrm{H}_{2} \mathrm{O}\right)\right] \mathrm{Br}$ complexes as shown in Figure 4.4. With an excitation selected at $450 \mathrm{~nm}$, the emission spectra show a range of emission maxima centered at 580 and $610 \mathrm{~nm}$, with the bpym complex having a lower emission centered at $520 \mathrm{~nm}$.

Using one of the $\left[\operatorname{Re}(\mathrm{L} \sim \mathrm{L})(\mathrm{CO})_{3}\left(\mathrm{H}_{2} \mathrm{O}\right)\right] \mathrm{Br}$ complexes as an example, the emission intensity as a function of concentration was measured. Figure 4.5 contains a plot of $\log$ (emission) versus 
$\log \left(\right.$ concentration) of $\left[\mathrm{Re}(\right.$ bpy $\left.)(\mathrm{CO})_{3}\left(\mathrm{H}_{2} \mathrm{O}\right)\right] \mathrm{Br}$ in aqueous solution. Based on this data, the detection limit for Re was calculated to be $9 \times 10^{-7} \mathrm{M}$ using Equation 2 (Long and Winefordner 1983)

$$
D L=\frac{k \cdot S_{b}}{m}
$$

where $D L$ is the detection limit, $k$ is a numerical constant, $m$ is the slope of the linear region of the plot and $S_{b}$ is the standard error for the blank measurements. In accord with International Union of Pure and Applied Chemistry (IUPAC) recommendations, a $k$ value of 3 was applied, which corresponds to a $99.87 \%$ confidence level.

Emission measurement of $\left[\mathrm{Tc}(\mathbf{C O})_{3}(\mathbf{b p y})\left(\mathrm{H}_{2} \mathrm{O}\right)\right]^{+}$. An aqueous sample of $\left[\mathrm{Tc}(\mathrm{CO})_{3}(\mathrm{bpy})\left(\mathrm{H}_{2} \mathrm{O}\right)\right]^{+}$ prepared as discussed above in Section 3.1 was placed within a micro-cuvette for cryogenic laser fluorescence spectroscopic analysis. Figure 4.6A shows the resulting fluorescence spectra of $\left[\mathrm{Tc}(\mathrm{CO})_{3}(\mathrm{bpy})\left(\mathrm{H}_{2} \mathrm{O}\right)\right]^{+}$as well as the $\left[\mathrm{Re}(\mathrm{CO})_{3}(\mathrm{bpy})\left(\mathrm{H}_{2} \mathrm{O}\right)\right]^{+}$complex for comparison. The emission bands are closely matched, with the rhenium complex slightly shifted to the blue (lower wavelength).

The emission band of the Tc target complex, $\left[\mathrm{Tc}(\mathrm{CO})_{3}(\mathrm{bpy})\left(\mathrm{H}_{2} \mathrm{O}\right)\right]^{+}$, is apparent with an emission maximum of approximately $600 \mathrm{~nm}$ (emission at red wavelength). The solution emission spectra of both $\left[\mathrm{Tc}(\mathrm{CO})_{3}\left(\mathrm{H}_{2} \mathrm{O}\right)\right]^{+}$and bpy starting materials were also measured as blank references (spectra not shown) and blank solutions show no observable emission signal above baseline. Along with spectral agreement with the rhenium analog complex, this indicates the observed emissive complex formed within solution is entirely from the formation of the technetium and ligand materials, demonstrating that the target complex $\left[\mathrm{Tc}(\mathrm{CO})_{3}(\mathrm{bpy})\left(\mathrm{H}_{2} \mathrm{O}\right)\right]^{+}$is the emissive species in solution.

Emission measurement of $\left[\mathbf{T c}(\mathbf{C O})_{3}(\text { phen })\left(\mathrm{H}_{2} \mathrm{O}\right)\right]^{+}$. An aqueous sample of $\left[\mathrm{Tc}(\mathrm{CO})_{3}(\mathrm{phen})\left(\mathrm{H}_{2} \mathrm{O}\right)\right]^{+}$ prepared as discussed above in Section 3.1 was placed in a micro-cuvette for cryogenic laser fluorescence spectroscopic analysis. Figure $4.6 \mathrm{~B}$ shows the resulting fluorescence spectra of $\left[\mathrm{Tc}(\mathrm{CO})_{3}(\text { phen })\left(\mathrm{H}_{2} \mathrm{O}\right)\right]^{+}$.

From this figure, the emission band of the Tc target complex, $\left[\mathrm{Tc}(\mathrm{CO})_{3}(\mathrm{phen})\left(\mathrm{H}_{2} \mathrm{O}\right)\right]^{+}$, is apparent. The solution emission spectra of both $\left[\mathrm{Tc}(\mathrm{CO})_{3}\left(\mathrm{H}_{2} \mathrm{O}\right)_{3}\right]^{+}$and phen starting materials were also measured as blank references (spectra not shown), and confirms the emission was from the Tc-ligand complex and not from the starting material. Along with spectral agreement with the rhenium analog complex, this indicates that the observed emissive complex formed within this solution is from a combination of the technetium- ligand complex from the starting materials, and indicates that the target complex, $\left[\mathrm{Tc}(\mathrm{CO})_{3}(\text { phen })\left(\mathrm{H}_{2} \mathrm{O}\right)\right]^{+}$, is the emissive species in solution. The emission maximum for the $\left[\mathrm{Tc}(\mathrm{CO})_{3}(\mathrm{phen})\left(\mathrm{H}_{2} \mathrm{O}\right)\right]^{+}$complex is observed at approximately $540 \mathrm{~nm}$ (emission at red-orange wavelength). 

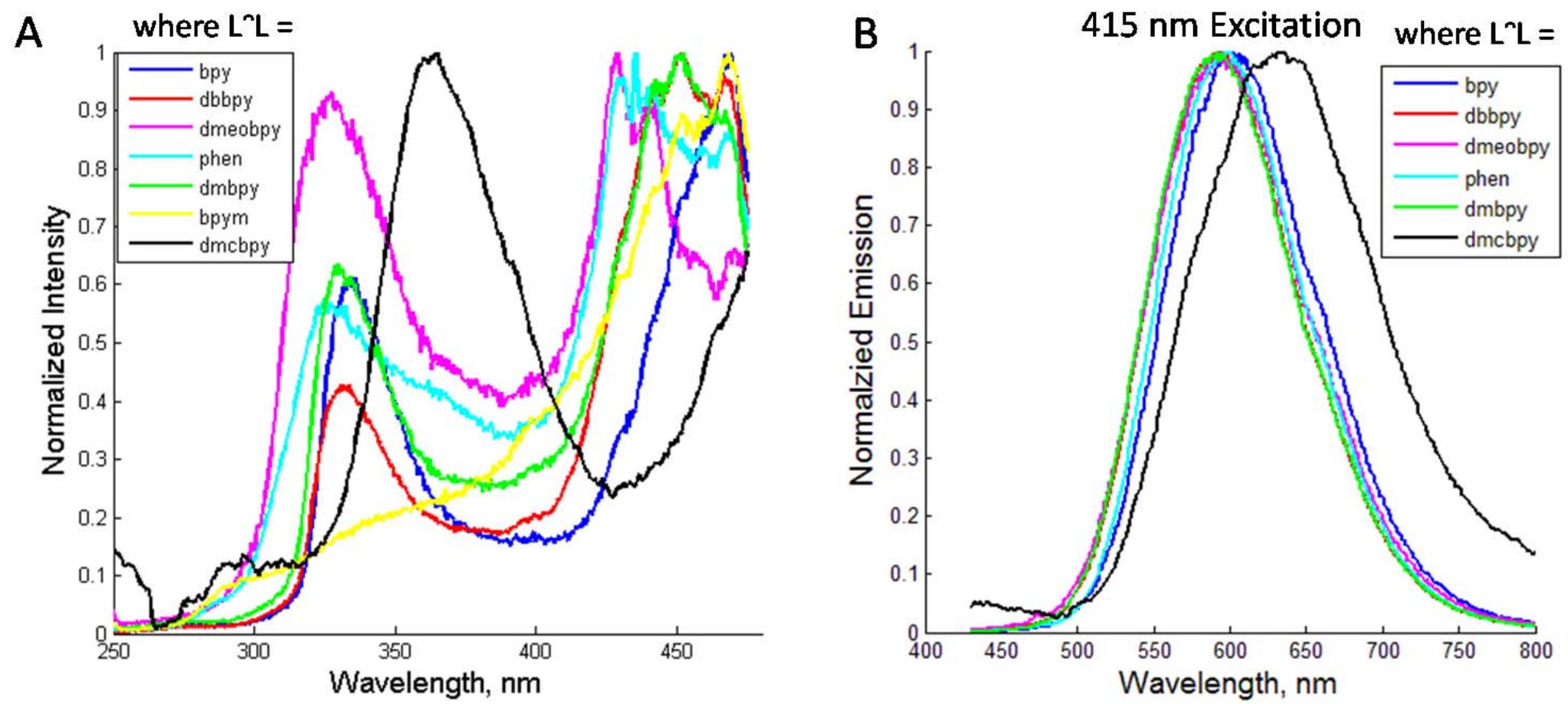

Figure 4.1. (A) Excitation and (B) Emission (415 nm excitation) Spectra for $\operatorname{Re}(\mathrm{L} \sim \mathrm{L})(\mathrm{CO})_{3} \mathrm{Cl}$ Complexes Where $\mathrm{L} \cap \mathrm{L}=2,2^{\prime}$ '-bipyridine (bpy); 4,4'-di-tert-butyl-2,2'-bpy (dbbpy); 4,4'-dimethoxy-2,2'-bpy (dmeobpy); 4,4'-dimethyl-bpy (dmbpy); 1,10-phenanthroline (phen); and 2,2'-bipyrimidine (bpym) 


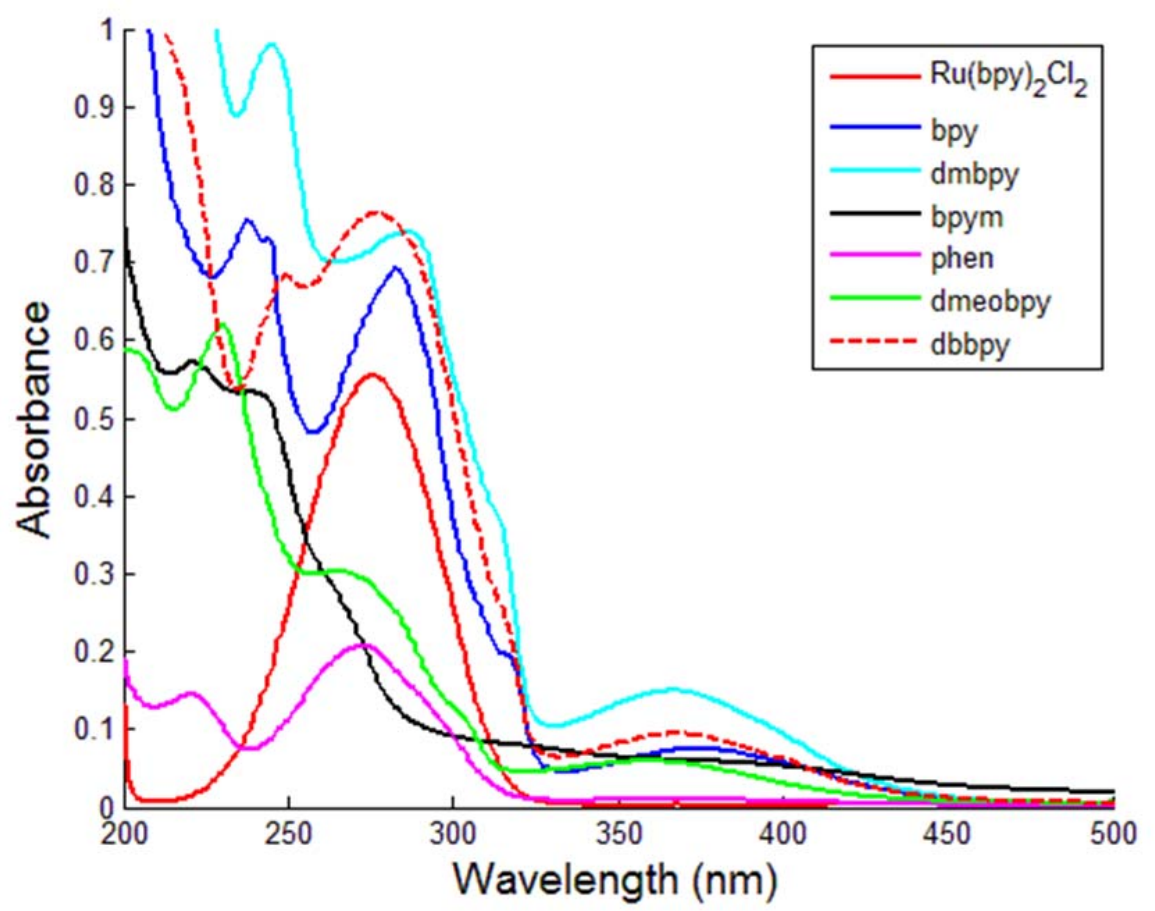

Figure 4.2. Absorption Spectra of $\left[\mathrm{Re}(\mathrm{L} \cap \mathrm{L})(\mathrm{CO})_{3}\left(\mathrm{H}_{2} \mathrm{O}\right)\right] \mathrm{Br}$ Complexes Where $\mathrm{L} \cap \mathrm{L}=2,2^{\prime}$ '-bipyridine (bpy); 4,4'-di-tert-butyl-2,2'-bpy (dbbpy); 4,4'-dimethoxy-2,2'-bpy (dmeobpy); 4,4'dimethyl-bpy (dmbpy); 1,10-phenanthroline (phen); and 2,2'-bipyrimidine (bpym), and the Model $\mathrm{Ru}(\mathrm{bpy})_{2} \mathrm{Cl}_{2}$ Complex

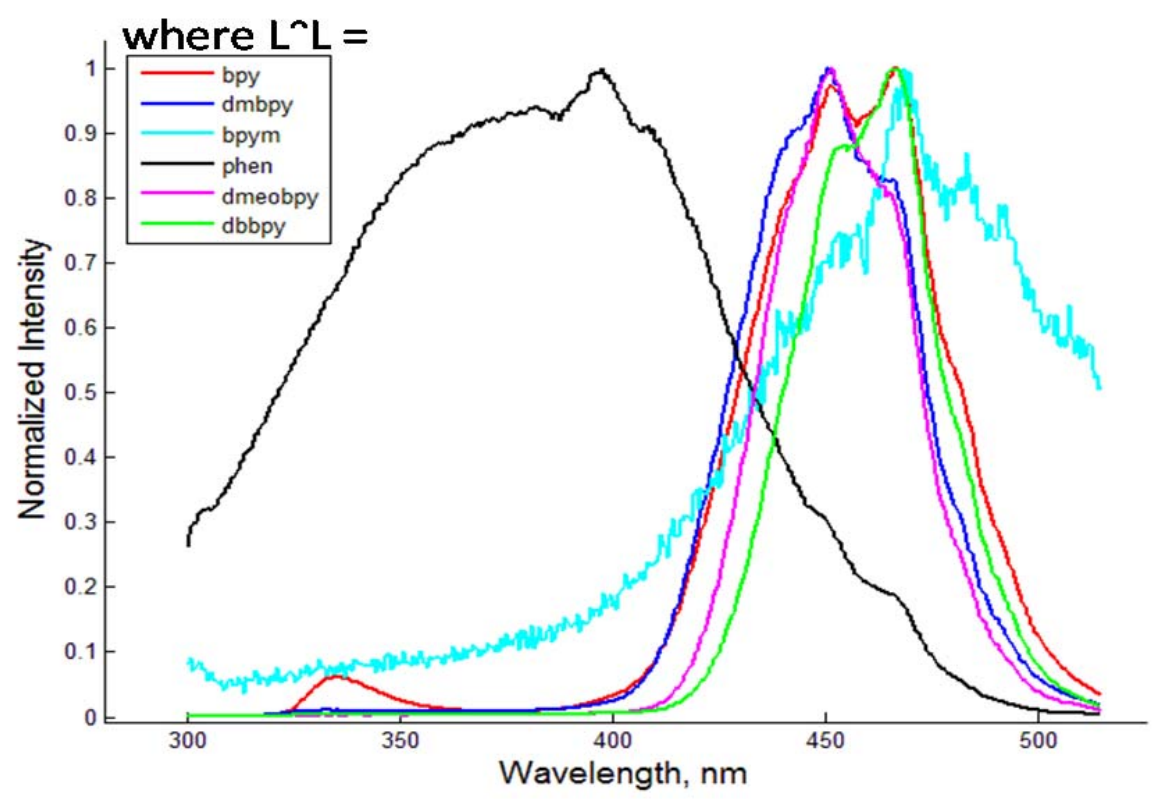

Figure 4.3. Excitation Spectra for $\left[\operatorname{Re}(\mathrm{L} \cap \mathrm{L})(\mathrm{CO})_{3}\left(\mathrm{H}_{2} \mathrm{O}\right)\right] \mathrm{Br}$ Complexes Where $\mathrm{L} \cap \mathrm{L}=2,2^{\prime}$-bipyridine (bpy); 4,4'-di-tert-butyl-2,2'-bpy (dbbpy); 4,4'-dimethoxy-2,2'-bpy (dmeobpy); 4,4'-dimethyl-bpy (dmbpy); 1,10-phenanthroline (phen); and 2,2'-bipyrimidine (bpym) 


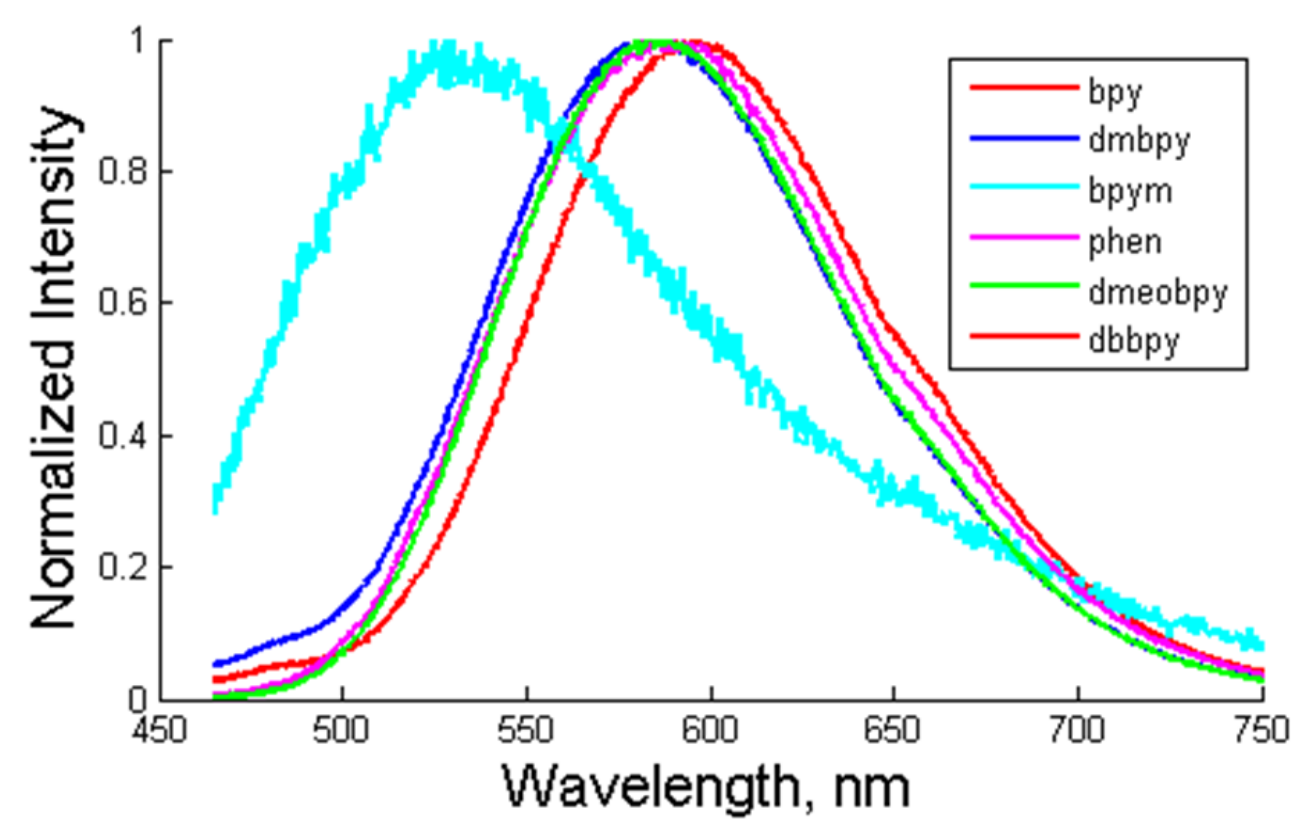

Figure 4.4. Emission Spectra for $\left[\mathrm{Re}(\mathrm{L} \sim \mathrm{L})(\mathrm{CO})_{3}\left(\mathrm{H}_{2} \mathrm{O}\right)\right] \mathrm{Br}$ Complexes $(450 \mathrm{~nm}$ excitation) Where $\mathrm{L} \cap \mathrm{L}=2,2$ '-bipyridine (bpy); 4,4'-di-tert-butyl-2,2'-bpy (dbbpy); 4,4'-dimethoxy-2,2'-bpy (dmeobpy); 4,4'-dimethyl-bpy (dmbpy); 1,10-phenanthroline (phen); and 2,2'-bipyrimidine (bpym)

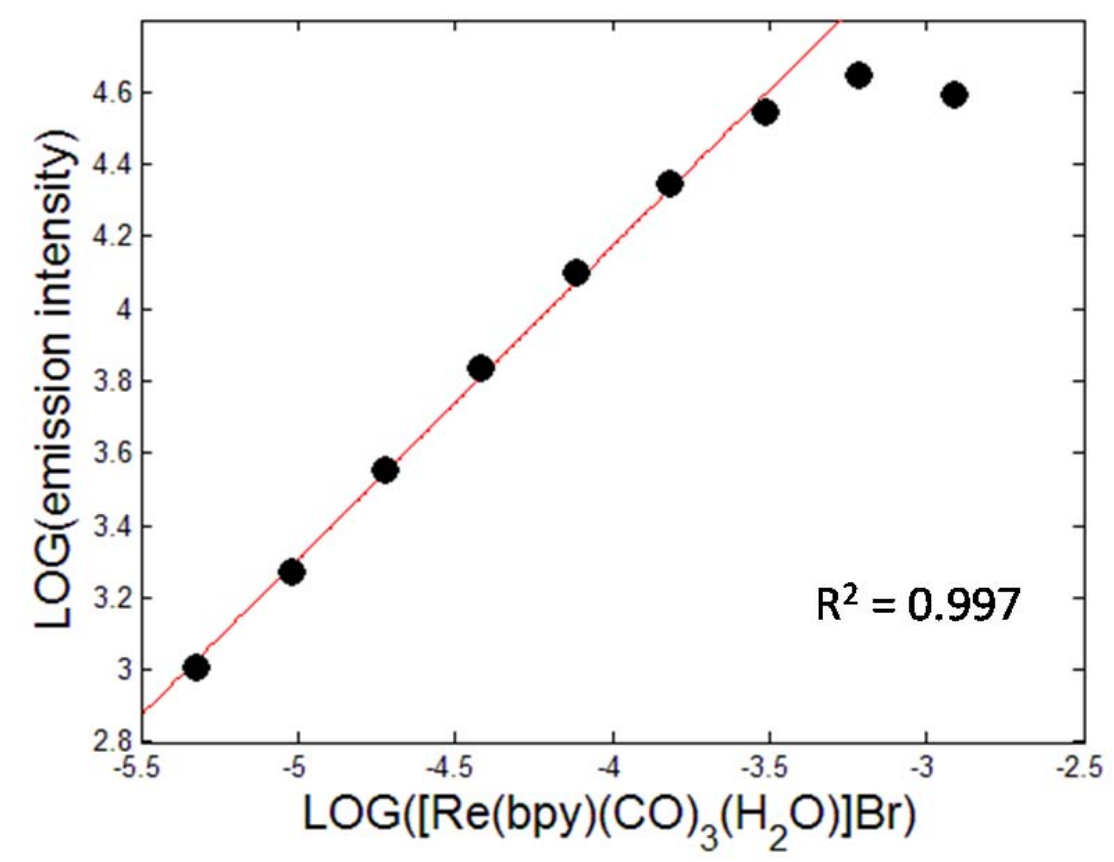

Figure 4.5. Plot of $\log \left(\right.$ emission) versus $\log$ (concentration) of $\left[\mathrm{Re}(\mathrm{bpy})(\mathrm{CO})_{3}\left(\mathrm{H}_{2} \mathrm{O}\right)\right] \mathrm{Br}$ in Aqueous Solution. The detection limit was calculated to be $9 \times 10^{-7} \mathrm{M}$ 

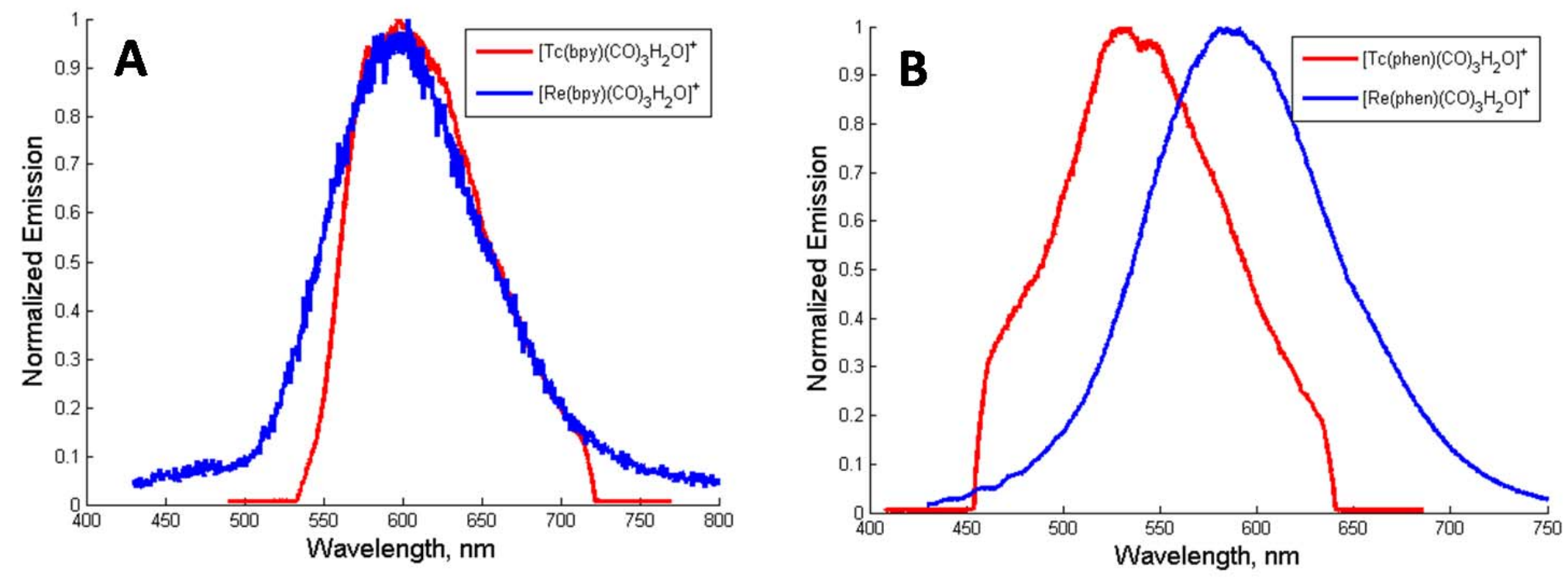

Figure 4.6. Emission Spectral Overlay of $\mathrm{A})\left[\mathrm{Tc}(\mathrm{bpy})(\mathrm{CO})_{3}\left(\mathrm{H}_{2} \mathrm{O}\right)\right]^{+}$and $\left[\operatorname{Re}(\mathrm{bpy})(\mathrm{CO})_{3}\left(\mathrm{H}_{2} \mathrm{O}\right)\right]^{+}$, and $\left.\mathrm{B}\right)\left[\mathrm{Tc}(\mathrm{phen})(\mathrm{CO})_{3}\left(\mathrm{H}_{2} \mathrm{O}\right)\right]^{+}$and $\left[\operatorname{Re}(\text { phen })(\mathrm{CO})_{3}\left(\mathrm{H}_{2} \mathrm{O}\right)\right]^{+}$ 


\subsection{Electrochemical Measurements of $\operatorname{Re}(\mathrm{L} \sim \mathrm{L})(\mathrm{CO})_{3} \mathrm{Cl}$ and $\left[\operatorname{Re}(\right.$ bpy $\left.)(\mathrm{CO})_{3}\left(\mathrm{H}_{2} \mathrm{O}\right)\right] \mathrm{Br}$ Complexes}

To achieve required selectivity, reversible electrochemistry of target analyte complexes is desired. Changing the oxidation state of the complex through reversible electrochemistry allows for the creation and quenching of the fluorescence signal from the sample. This changing signal, which is triggered through the electrochemical sensor, creates a modulated (on/off) signal within the sensor platform. The ability to monitor a changing (modulated) signal of the Tc analyte complex allows for the distinguishing of this signal from a constant fluorescence signal originating from a potential interfering species.

Cyclic voltammagrams $(\mathrm{CVs})$ of $\mathrm{Re}(\mathrm{L} \cap \mathrm{L})(\mathrm{CO})_{3} \mathrm{Cl}$ complexes (at a concentration of $5 \mathrm{mM}$ ) that are analogs to the Tc-carbonyl target system are shown in Figure 4.7, including complexes

A) $\operatorname{Re}($ bpy $)(\mathrm{CO})_{3} \mathrm{Cl}$; B $) \operatorname{Re}($ dbbpy $)(\mathrm{CO})_{3} \mathrm{Cl}$; C) $\mathrm{Re}(\mathrm{dmbpy})(\mathrm{CO})_{3} \mathrm{Cl}$; D) $\operatorname{Re}(\mathrm{dpym})(\mathrm{CO})_{3} \mathrm{Cl}$;

E) $\mathrm{Re}($ dmcbpy $)(\mathrm{CO})_{3} \mathrm{Cl}$; F) $\mathrm{Re}($ dmeobpy $)(\mathrm{CO})_{3} \mathrm{Cl}$; and $\left.\mathrm{G}\right) \mathrm{Re}(\mathrm{phen})(\mathrm{CO})_{3} \mathrm{Cl}$. In general, the cyclic voltammagrams were scanned at a $100 \mathrm{mV} / \mathrm{s}$ scan rate in a potential window of $+1.6 \mathrm{~V}$ to $-1.6 \mathrm{~V}$, with a supporting electrolyte of $0.1-\mathrm{M} \mathrm{TBAPF}_{6}$ in acetonitrile. All CVs showed a reversible ligand-based reduction near $-1.5 \mathrm{~V}$ (ascribed to $\mathrm{L}^{0} / \mathrm{L}^{-}$based on similar complexes (Richter et al. 1996)), and a non-reversible metal-metal-based oxidation near $+1.4 \mathrm{~V}$ (labeled $\mathrm{Re}^{\mathrm{I}} / \mathrm{Re}^{\mathrm{II}}$ ).

$\mathrm{CV}$ measurements of $\left[\operatorname{Re}(\mathrm{L} \sim \mathrm{L})(\mathrm{CO})_{3}\left(\mathrm{H}_{2} \mathrm{O}\right)\right] \mathrm{Br}$ complexes are shown in Figure 4.8 and include complexes A) Re(bpy) $\left.\left.(\mathrm{CO})_{3}\left(\left(\mathrm{H}_{2} \mathrm{O}\right)\right] \mathrm{Br} ; \mathrm{B}\right) \mathrm{Re}(\mathrm{dbbpy})(\mathrm{CO})_{3}\left(\left(\mathrm{H}_{2} \mathrm{O}\right)\right] \mathrm{Br} ; \mathrm{C}\right) \operatorname{Re}(\mathrm{dmbpy})(\mathrm{CO})_{3}\left(\left(\mathrm{H}_{2} \mathrm{O}\right)\right] \mathrm{Br}$; D) $\operatorname{Re}($ dpym $)(\mathrm{CO})_{3}\left(\left(\mathrm{H}_{2} \mathrm{O}\right)\right] \mathrm{Br}$; and $\left.\mathrm{E}\right) \operatorname{Re}($ dmeobpy $)(\mathrm{CO})_{3}\left(\left(\mathrm{H}_{2} \mathrm{O}\right)\right] \mathrm{Br}$. Similar experimental parameters, Re complex concentrations, and conditions were used in this system as for the chloro-complexes discussed in the preceding paragraph with the same potential scan window selected, $+1.6 \mathrm{~V}$ to $-1.6 \mathrm{~V}$. All CVs showed a reversible ligand-based reduction near $-1.5 \mathrm{~V}$ (ascribed to $\mathrm{L}^{0} / \mathrm{L}^{-}$based on similar complexes (Richter et al. 1996)), and a non-reversible metal-metal-based oxidation near $+1.4 \mathrm{~V}$ (labeled $\left.\mathrm{Re}^{\mathrm{I}} / \mathrm{Re}^{\mathrm{II}}\right)$.

Combining the optical measuements from Section 4.1 with the electrochemical measurements in this section, it was possible to compare the emission energy to the redox potential of each metal complex. Figure 4.9 shows the correlation of the emission energy $\left(\mathrm{E}_{\mathrm{em}}\right)$ to the difference in redox potentials $\left(\Delta \mathrm{E}_{1 / 2}=\mathrm{E}_{1 / 2}\left(\operatorname{Re}^{\mathrm{II}} / \mathrm{Re}^{\mathrm{I}}\right)-\mathrm{E}_{1 / 2}\left(\mathrm{~L} / \mathrm{L}^{-}\right)\right.$for $(\mathrm{A}) \operatorname{Re}(\mathrm{L} \sim \mathrm{L})(\mathrm{CO})_{3} \mathrm{Cl}$, and $(\mathrm{B})\left[\operatorname{Re}(\mathrm{L} \sim \mathrm{L})(\mathrm{CO})_{3}\left(\mathrm{H}_{2} \mathrm{O}\right)\right] \mathrm{Br}$, where the ligands are varied). The variation in ligand tunes the excited state emission energy, as well as the reduction potential for these complexes. The best fit of the line for each system (chloro-complexes and aquo-complexes) is shown in Figure 4.9, with $\mathrm{R}^{2}=0.9926$ for $\left.\mathrm{Re}(\mathrm{L} \sim \mathrm{L})(\mathrm{CO})_{3} \mathrm{Cl}\right)$ and $\mathrm{R}^{2}=0.9138$ for $\left[\operatorname{Re}(\mathrm{L} \sim \mathrm{L})(\mathrm{CO})_{3}\left(\mathrm{H}_{2} \mathrm{O}\right)\right] \mathrm{Br}$, which indicates a strong correlation between these two parameters. 

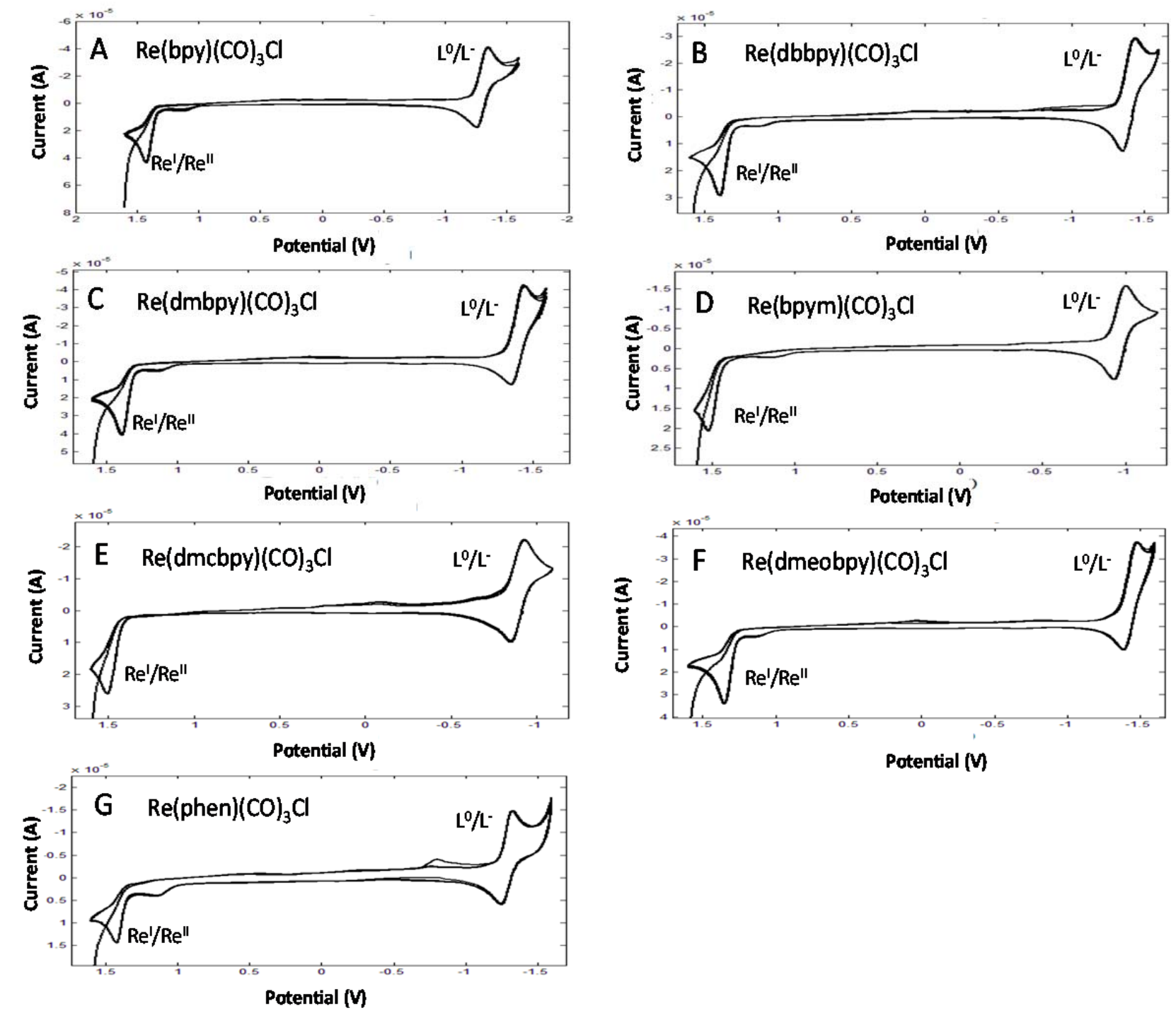

Potential ( $V$

Figure 4.7. Cyclic Voltammetry Measurements of $\operatorname{Re}(\mathrm{L} \sim \mathrm{L})(\mathrm{CO})_{3} \mathrm{Cl}$ Complexes. The list includes: A) $\left.\operatorname{Re}(\mathrm{bpy})(\mathrm{CO})_{3} \mathrm{Cl} ; \mathrm{B}\right) \mathrm{Re}(\mathrm{dbbpy})(\mathrm{CO})_{3} \mathrm{Cl}$; C) $\operatorname{Re}(d m b p y)(\mathrm{CO})_{3} \mathrm{Cl}$; D) $\operatorname{Re}(\mathrm{dpym})(\mathrm{CO})_{3} \mathrm{Cl}$; E) $\operatorname{Re}($ dmcbpy $)(\mathrm{CO})_{3} \mathrm{Cl}$; and $\left.\mathrm{F}\right) \operatorname{Re}($ dmeobpy $)(\mathrm{CO})_{3} \mathrm{Cl}$; and $\left.\mathrm{G}\right) \operatorname{Re}(\mathrm{phen})(\mathrm{CO})_{3} \mathrm{Cl}$. 

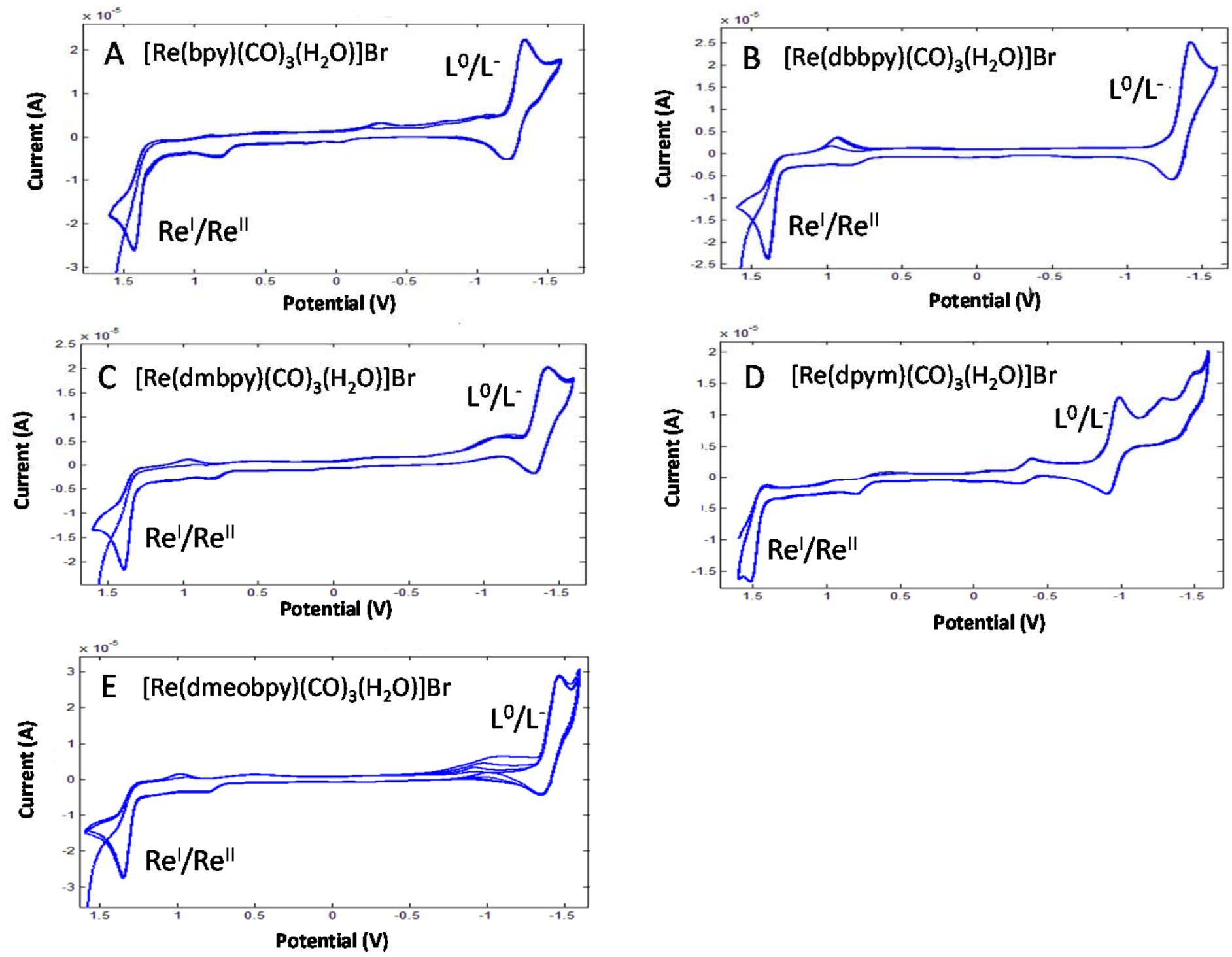

Figure 4.8. Cyclic Voltammetry Measurements of $\left[\operatorname{Re}(\mathrm{L} \sim \mathrm{L})(\mathrm{CO})_{3}\left(\mathrm{H}_{2} \mathrm{O}\right)\right] \mathrm{Br}$ Complexes. The list includes: $\left.\left.\mathrm{A}\right) \mathrm{Re}(\mathrm{bpy})(\mathrm{CO})_{3}\left(\mathrm{H}_{2} \mathrm{O}\right)\right] \mathrm{Br}$; B) $\operatorname{Re}($ dbbpy $\left.)(\mathrm{CO})_{3}\left(\mathrm{H}_{2} \mathrm{O}\right)\right] \mathrm{Br}$; C) $\operatorname{Re}($ dmbpy $\left.)(\mathrm{CO})_{3}\left(\mathrm{H}_{2} \mathrm{O}\right)\right] \mathrm{Br}$; D) $\left.\operatorname{Re}(\mathrm{dpym})(\mathrm{CO})_{3}\left(\mathrm{H}_{2} \mathrm{O}\right)\right] \mathrm{Br}$; and E) $\left.\operatorname{Re}(\mathrm{dmeobpy})(\mathrm{CO})_{3}\left(\mathrm{H}_{2} \mathrm{O}\right)\right] \mathrm{Br}$. 

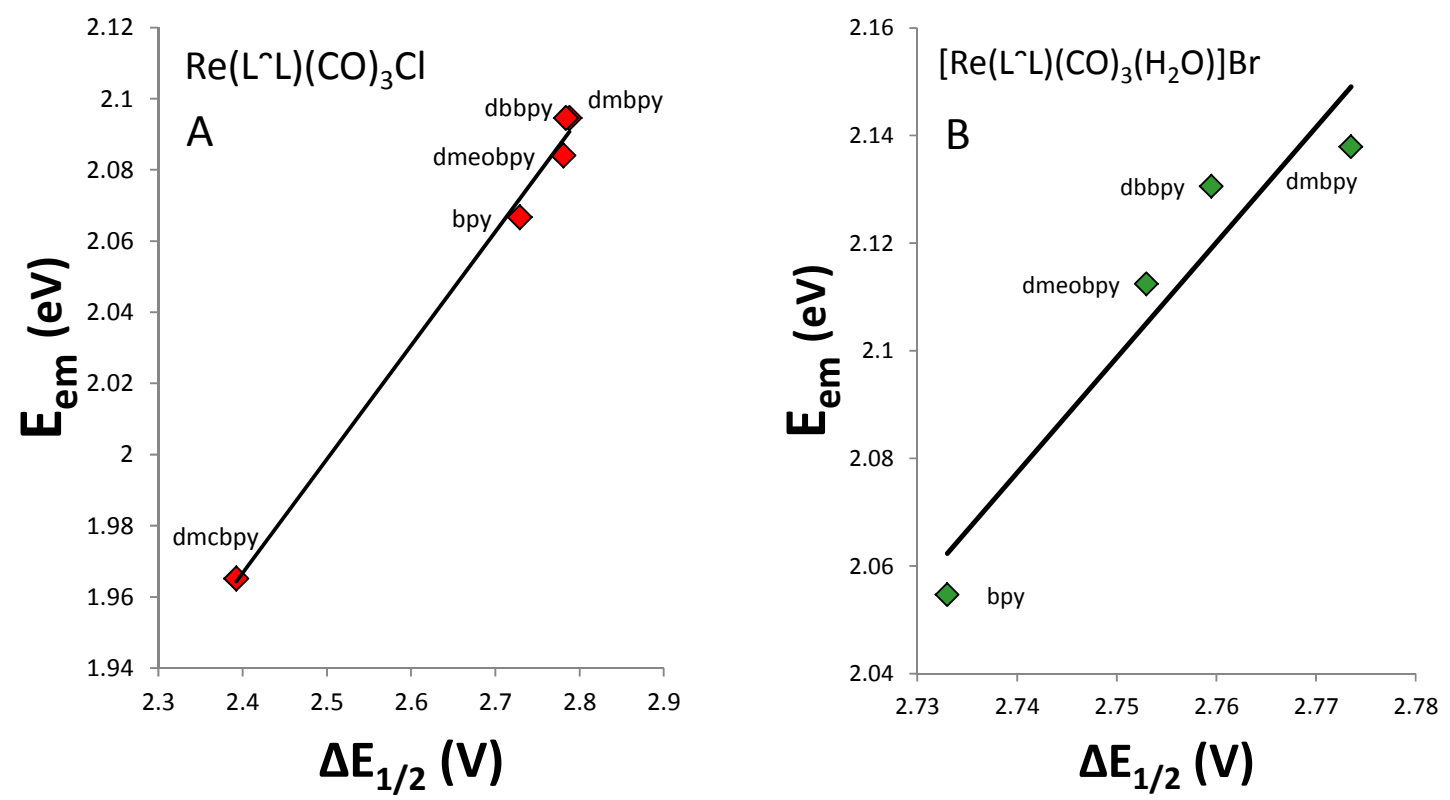

Figure 4.9. Correlation of Emission Energy $\left(\mathrm{E}_{\mathrm{em}}\right)$ and Difference in Redox Potentials $\left(\Delta \mathrm{E}_{1 / 2}=\mathrm{E}_{1 / 2}\left(\operatorname{Re}^{\mathrm{II}} / \operatorname{Re}^{\mathrm{I}}\right)-\mathrm{E}_{1 / 2}\left(\mathrm{~L} / \mathrm{L}^{-}\right)\right.$for $\left.\mathrm{A}\right) \operatorname{Re}(\mathrm{L} \sim \mathrm{L})(\mathrm{CO})_{3} \mathrm{Cl}$, and B) $\left.\left[\operatorname{Re}(\mathrm{L} \cap \mathrm{L})(\mathrm{CO})_{3}\left(\mathrm{H}_{2} \mathrm{O}\right)\right] \mathrm{Br}\right)$. The line represents the best fit though the data with $\mathrm{R}^{2}=0.9926\left(\mathrm{Re}(\mathrm{L} \sim \mathrm{L})(\mathrm{CO})_{3} \mathrm{Cl}\right)$ and $\mathrm{R}^{2}=0.9138\left(\left[\operatorname{Re}(\mathrm{L} \sim \mathrm{L})(\mathrm{CO})_{3}\left(\mathrm{H}_{2} \mathrm{O}\right)\right] \mathrm{Br}\right)$.

\subsection{Spectroelectrochemical Measurements}

This section focuses on the spectroelectrochemical sensor methodology using model compounds and analogs to the Tc-carbonyl system. This section details the combined spectroscopic and electrochemical (spectroelectrochemical) measurements supporting this work. By combining the reversible electrochemical reduction/oxidation of the target analyte complex while measuring the fluorescence signal spectroscopically, it is possible to monitor a changing (modulated) signal from the Tc analyte complex. The ability to perform combined spectroscopy and electrochemistry was demonstrated using fluorescence modulation of the $\left[\mathrm{Re}(\mathrm{bpy})(\mathrm{CO})_{3}\left(\mathrm{H}_{2} \mathrm{O}\right)\right] \mathrm{Br}$ in a spectroelectrochemical cell.

The $\left[\mathrm{Ru}(\mathrm{bpy})_{3}\right]^{2+}$ complex, due to its reversible electrochemical redox behavior and emissive optical properties, is used here as a model complex to test the properties of the selective partitioning film for electrochemical and optical emission measurements for our study. Its use is to optimize the experimental system of the partitioning film prior to testing with Re-carbonyl and Tc-carbonyl complexes. A spectroelectrochemical experiment using the $\left[\mathrm{Ru}(\mathrm{bpy})_{3}\right]^{2+}$ complex was performed and is shown in Figure 4.10. The potential was stepped from $1 \mathrm{~V}$ to $1.1 \mathrm{~V}$ in steps of $0.02 \mathrm{~V}$ where the applied potential was held for 10 minutes after each step. The experiment was performed using a BASi thin layer cell with Pt mesh working electrode, $\mathrm{Pt}$ auxiliary electrode, and an $\mathrm{Ag} / \mathrm{AgCl}$ reference electrode. 

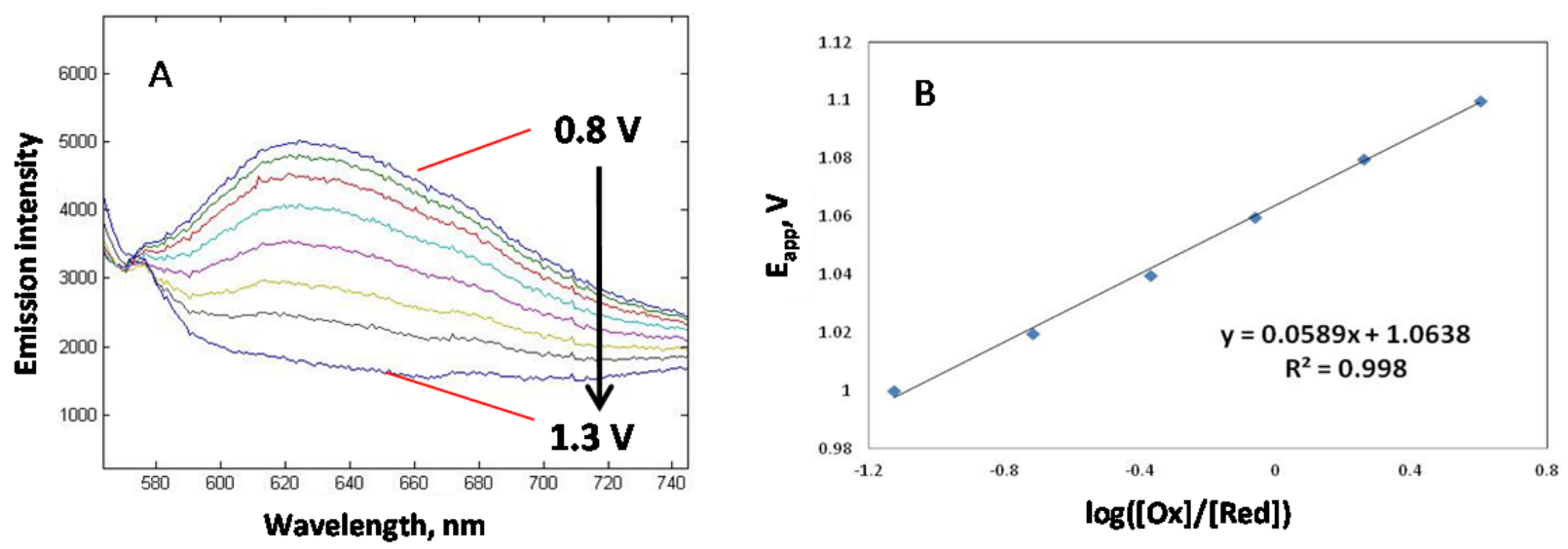

Figure 4.10. (A) Modulation of Luminescence Intensity of an Aqueous Solution of $5 \mathrm{mM}\left[\mathrm{Ru}(\mathrm{bpy})_{3}\right]^{2+}$ in $0.1 \mathrm{M} \mathrm{KNO}_{3}$ with Time on the Application of Voltage $\left(\lambda_{\mathrm{ex}}=532 \mathrm{~nm}\right)$; (B) Nernst Plot of $\log [\mathrm{Ox}] /[\mathrm{Red}]$ vs. $\mathrm{E}_{\text {app }}$ vs. $\mathrm{Ag} / \mathrm{AgCl}$ at $620 \mathrm{~nm}$

Emission spectra, redox potentials, and electron transfer stoichiometries were also determined by thin-layer spectroelectrochemistry (Deangelis and Heineman 1976; Kissinger and Heineman 1996). In our experimental technique, $\mathrm{Ru}^{3+}$ is incrementally converted to $\mathrm{Ru}^{2+}$ by a series of applied potentials so that the ratio of $\mathrm{Ru}^{3+}$ to $\mathrm{Ru}^{2+}$ in the thin-layer cell is varied according to the Nernst Equation:

$$
E_{\text {app }}=E^{0^{\prime}}+2.303\left(\frac{R T}{n F}\right) \log \frac{[\text { Ox }]}{[\text { Red }]}
$$

where $\mathrm{E}^{\mathrm{o}}$ is the formal reduction potential, $\mathrm{R}$ is the gas constant, $\mathrm{T}$ is the temperature in Kelvin, $\mathrm{F}$ is Faraday's constant, $\mathrm{n}$ is the electron transfer stoichiometry, and [Ox] and [Red] are the respective concentrations of the oxidized and reduced species. The ratio $[\mathrm{Ox}] /[\mathrm{Red}]$ at each applied potential $E_{\text {app }}$ was estimated from $\left(I-I_{\mathrm{red}}\right) /\left(I_{\mathrm{ox}}-I\right)$, where $I$ is the emission intensity at a given wavelength, according to literature methods (Deangelis and Heineman 1976; Kissinger and Heineman 1996). Figure 4.10A shows the emission spectra for $5 \mathrm{mM}\left[\mathrm{Ru}(\mathrm{bpy})_{3}\right]^{2+}$ in aqueous $0.1 \mathrm{M} \mathrm{KNO}_{3}$ when various potentials are applied. The spectrum with the least emission intensity at $620 \mathrm{~nm}$ is at $\mathrm{E}_{\text {app }}=1.1 \mathrm{~V}$ when $\mathrm{Ru}$ is fully oxidized to $\mathrm{Ru}^{3+}$, while the spectrum with the most emission intensity at $620 \mathrm{~nm}$ is at $E_{\text {app }}=1.0 \mathrm{~V}$, which is the fully reduced form, $\mathrm{Ru}^{2+}$.

Based on the Nernst analysis, the slope of the fit of the line of $E_{\text {app }} \mathrm{vs} \log ([\mathrm{Ox}] /[\mathrm{Red}])$, yields the $\mathrm{E}^{\mathrm{o}^{\prime}}$ value of $1.0634 \mathrm{~V}$ as the $\mathrm{y}$-intercept value, which is close to the $\mathrm{CV}$ value measured above (1.065 V); see the Figure 4.10B. The slope yields the Nersnt constant of 0.0589 , which is close (within $0.3 \%$ ) to theoretical value $(0.0591)$ for the expected one-electron transfer for the $\mathrm{Ru}(\mathrm{II} / \mathrm{III})$ couple.

The modulation of $5 \mathrm{mM}\left[\mathrm{Ru}(\mathrm{bpy})_{3}\right]^{2+/ 3+}$ in $0.1 \mathrm{M} \mathrm{KNO}_{3}$ was performed using a step potential reduction/oxidation wave form in the spectroelectrochemical cell, as shown in Figure 4.11. The potential was modulated as a step function between $1.3 \mathrm{~V}$ and $0.8 \mathrm{~V}$ where the potential was held for 5 minutes at each potential. A total of three redox cycles were performed. When the potential was held at $0.8 \mathrm{~V}$, the $\mathrm{Ru}$ complex was reduced to the $\mathrm{Ru}(\mathrm{II})$ form $\left(\left[\mathrm{Ru}(\mathrm{bpy})_{3}\right]^{2+}\right)$, which is emissive; when the potential was held at $1.3 \mathrm{~V}$, the $\mathrm{Ru}$ complex was oxidized to the $\mathrm{Ru}(\mathrm{III})$ form $\left(\left[\mathrm{Ru}(\mathrm{bpy})_{3}\right]^{3+}\right)$, which is non-emissive. 
The experiment was completed using the spectroelectrochemical apparatus with a Pt wire working electrode, and Pt auxiliary, and an $\mathrm{Ag} / \mathrm{AgCl}$ micro reference electrode.

The optical and electrochemical measurements provided in Sections 4.1 and 4.2, respectively, provide the optical and electrochemical parameters for optimizing the spectroelectrochemical detection system for Tc and the Re analog target complexes.

The absorption mode spectroelectrochemical measurement of $\operatorname{Re}(\mathrm{dbbpy})(\mathrm{CO})_{3} \mathrm{Cl}$ is shown in Figure 4.12. The potential was modulated as a step function, between -1.0 and $-1.6 \mathrm{~V}$, and held for 5 minutes at each potential. The solution contained $2 \mathrm{mM} \mathrm{Re}(\mathrm{dbbpy})(\mathrm{CO})_{3} \mathrm{Cl}$ with $0.1 \mathrm{M} \mathrm{TBACl}$ as the supporting electrolyte in dimethyl formamide (DMF) solution. This figure demonstrates the ability to electrochemically modulate the $\operatorname{Re}(\mathrm{I} / 0)$ complex while simultaneously monitoring the optical absorption signal for the reduced and oxidized forms for the $\left[\mathrm{Re}(\mathrm{dbbpy})(\mathrm{CO})_{3} \mathrm{Cl}\right]^{0 / 1-}$ complex.

The emission mode spectroelectrochemical measurement for $1.25 \mathrm{mM}\left[\mathrm{Re}(\mathrm{bpy})(\mathrm{CO})_{3}\left(\mathrm{H}_{2} \mathrm{O}\right)\right] \mathrm{Br}$ in $0.1 \mathrm{M} \mathrm{TBAPF}_{6}$ solution in acetonitrile is shown in Figure 4.13. This experiment demonstrates the feasibility of using the the $\left[\mathrm{Re}(\mathrm{L} \sim \mathrm{L})(\mathrm{CO})_{3}\left(\mathrm{H}_{2} \mathrm{O}\right)\right]^{+}$class of compounds for utilizing the spectroelectrochemical technique to ultimately develop a sensor. 

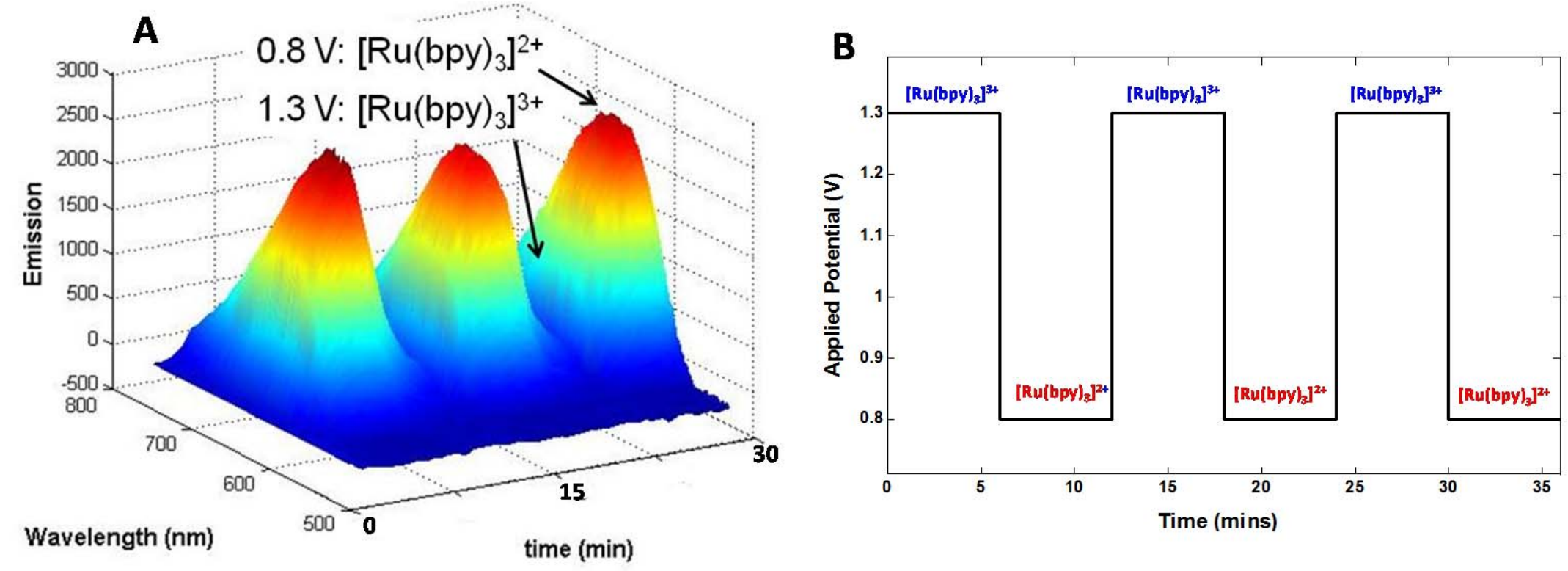

Figure 4.11. (A) Modulation of $5 \mathrm{mM}\left[\mathrm{Ru}(\mathrm{bpy})_{3}\right]^{2+/ 3+}$ in $0.1 \mathrm{M} \mathrm{KNO}_{3}$; (B) Potential was Modulated Between $1.3 \mathrm{~V}$ and $0.8 \mathrm{~V}$ Where the Potential was Held for Five Minutes. Experiment was completed using the spectroelectrochemical apparatus with a Pt wire working electrode, and $\mathrm{Pt}$ auxiliary, and an $\mathrm{Ag} / \mathrm{AgCl}$ micro reference electrode. 

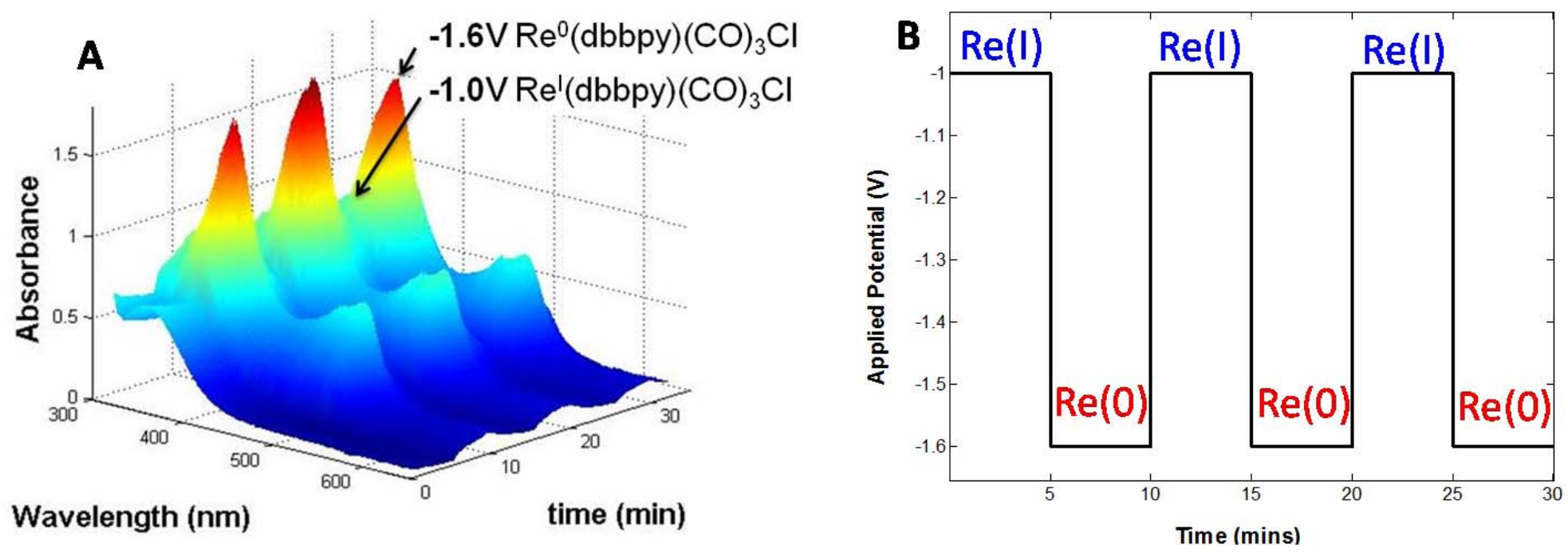

Figure 4.12. Absorbance Modulation for $2 \mathrm{mM} \operatorname{Re}(\mathrm{dbbpy})(\mathrm{CO})_{3} \mathrm{Cl}$ and $0.1 \mathrm{M}$ TBACl Solution in DMF. The potential was modulated between -1.0 and $-1.6 \mathrm{~V}$ and potential was held for 5 minutes after each potential change. 

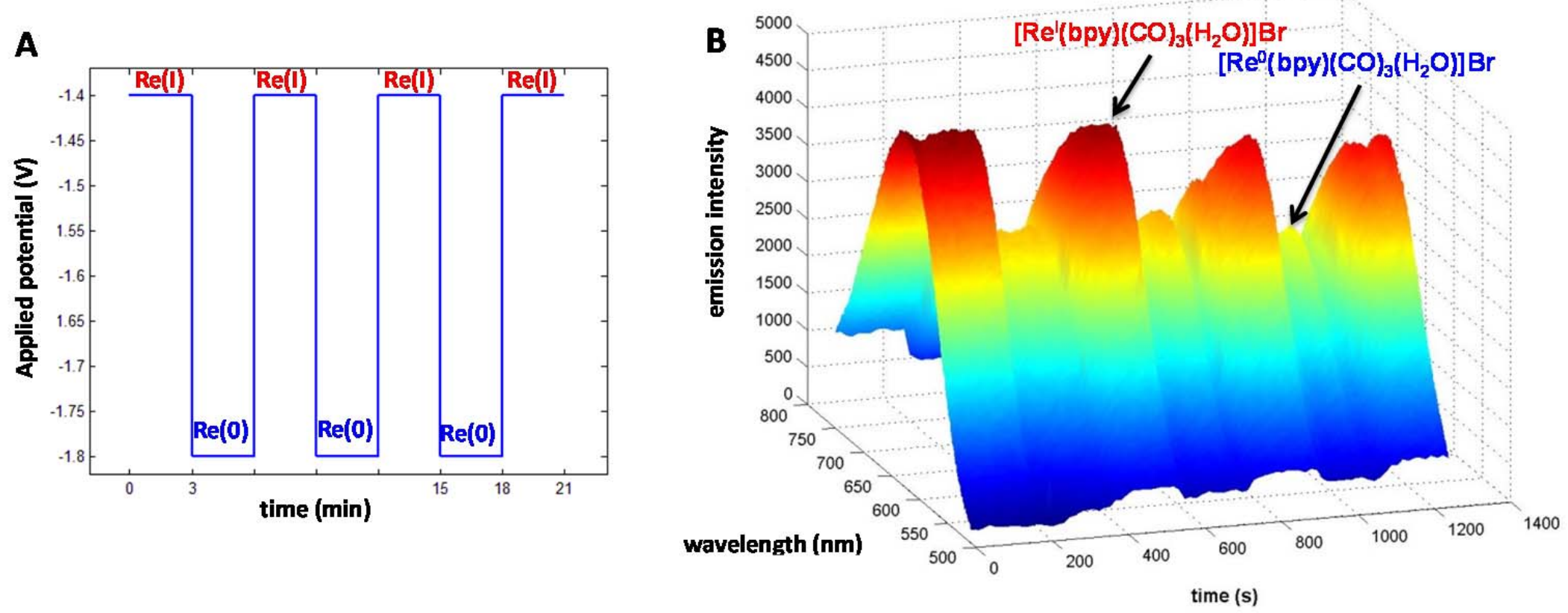

Figure 4.13. Emission Modulation for $1.25 \mathrm{mM}\left[\operatorname{Re}(\mathrm{bpy})(\mathrm{CO})_{3}\left(\mathrm{H}_{2} \mathrm{O}\right)\right] \mathrm{Br}$ and $0.1 \mathrm{M} \mathrm{TBAPF}_{6}$ Solution in Acetonitrile. The potential was modulated between -1.4 and $-1.8 \mathrm{~V}$ and held for 3 minutes after each change. 


\subsection{Selective Partitioning of Re-carbonyl and Other Model Complexes Into lon-selective Films}

This section focuses on the ion-selective partitioning film used in the spectroelectrochemical sensor methodology, using model compounds and rhenium analogs for the Tc-carbonyl system. This section details experiments associated with optimizing the ion-selective partitioning film measurements supporting this work. In order to increase sensitivity and selectivity, we are evaluating several polymer films for the application of selective uptake of Tc target complexes for use in the sensor apparatus.

We are developing sensor films for use in a spectroelectrochemical sensor for the Tc-tricarbonyl $\left(\left[\mathrm{Tc}(\mathrm{CO})_{3}\left(\mathrm{H}_{2} \mathrm{O}\right)_{3}\right]^{+}\right)$form of technetium-99 present in Hanford tank supernatants. ${ }^{99} \mathrm{Tc}$, a nuclear fission byproduct, has a very long half-life, no known non-radioactive isotopes, and has the potential to migrate in ground water with little retardation (Schulte and Scoppa 1987; Schwochau 2000). Natural abundance rhenium ( $\mathrm{Re}$ ) has been used as a surrogate for technetium (Tc), which is often used in medical applications as an imaging agent (Deng et al. 1997; Deutsch et al. 1986; Verbruggen 2005), and therefore has well-known electrochemical and optical properties (Deng et al. 1997; Kirchhoff et al. 1997; Kirchhoff et al. 1988; Lisbon et al. 1988; Roodt et al. 1991; Woolf 1961). Since analogous Re and Tc compounds generally have nearly identical chemical properties, we are initially targeting our studies using $\left[\mathrm{Re}(\mathrm{CO})_{3}\left(\mathrm{H}_{2} \mathrm{O}\right)_{3}\right]^{+}$, and will progress to using $\left[\mathrm{Tc}(\mathrm{CO})_{3}\left(\mathrm{H}_{2} \mathrm{O}\right)_{3}\right]^{+}$after the prototype sensor is tested. This section reports the advances in the development of a spectroelectrochemical sensor for $\left[\operatorname{Re}(\mathrm{CO})_{3}\left(\mathrm{H}_{2} \mathrm{O}\right)_{3}\right]^{+}$.

The spectroelectrochemical sensors developed by the University of Cincinnati (Andria et al. 2004; DiVirgilio-Thomas et al. 2000; Gao et al. 2001; Kaval et al. 2003; Maizels et al. 2002; Shi et al. 1997a; Shi et al. 1998; Shi et al. 1997b; Slaterbeck et al. 1999; Slaterbeck et al. 2000; Wansapura et al. 2007) consist of an optically transparent electrode (OTE) coated with a thin sensing film in contact with an aqueous sample phase. The thin film serves to preconcentrate the analyte and also excludes at least some of the potential interferences in the aqueous sample phase. Light propagating through the sensor by multiple internal reflections can interact with species contained within the thin film. For electrochemically reversible analytes that exhibit a change in color upon reduction or oxidation, absorption of the appropriate wavelength of light is modulated by using the applied potential to switch between reduced and oxidized forms of the analyte while intensity of the chosen wavelength is monitored. For analytes that undergo a change in fluorescence during manipulation of an electrochemically reversible redox couple, the emission of the appropriate wavelength of light is modulated by using the applied potential to switch between the reduced and oxidized forms of the analyte while the intensity of the chosen wavelength is monitored. Such a sensor is highly selective, as selective partitioning into the film, applied potentials for electrochemical oxidation/reduction, and absorption/fluorescence change at the observed wavelength simultaneously to provide three modes of selectivity. For example, the capability of such a sensor to detect ferrocyanide in actual nuclear waste stored in high-level waste tanks (Hanford Tank C-111) at the Department of Energy's Hanford site has been demonstrated previously(Maizels et al. 2002; Shi et al. 1997b). 


\section{Preparation of ion-selective thin films}

ITO electrodes were cleaned as previously described (Kaval et al. 2003) and masked with tape at both ends to allow for electrical connectivity. Polymer films were prepared by spin coating the polymer solution onto clean ITO at $3000 \mathrm{rpm}$ using a photo-resist spin coater (Headway Research Inc., model 1-PM101DT-R485) as follows:

Nafion. $50 \mu \mathrm{L}$ of $5 \mathrm{wt} \%$ Nafion stock solution was pipetted onto the ITO surface to form a film with thickness of $300 \mathrm{~nm}$. The procedure used has been described elsewhere. (Gao and Seliskar 1998; Gao et al. 1999; Gao et al. 2001).

SSEBS. $50 \mu \mathrm{L}$ of $5 \mathrm{wt} \%$ SSEBS stock solution was pipetted onto the ITO surface to form a film with variable thickness.

Film thicknesses were based on a previous recipe (Pantelic et al. 2009) and verified by ellipsometry. Films were soaked in supporting electrolyte for $30 \mathrm{~min}$ before electrochemistry experiments, except for the SSEBS films which were presoaked in supporting electrolyte up to $24 \mathrm{~h}$ before use in spectroelectrochemical experiments.

\section{Uptake experiments using ion-selective thin films}

A series of thin films were prepared using SSEBS and Nafion films. Figure 4.14 shows the results of a cyclic voltammetry experiment involving $1 \mathrm{mM}\left[\mathrm{Ru}(\mathrm{bpy})_{3}\right]^{2+}$, using $70 \mathrm{~nm}$ SSEBS film on ITO (Figure 4.14B), or $70 \mathrm{~nm}$ Nafion film on ITO (Figure 4.14C), compared to that of an uncoated ITO slide (Figure 4.14A). The SSEBS-coated slide showed an increase of approximately 2-3 times in current (Figure 4.14B) compared to the uncoated slide, while the Nafion-coated slide showed a much larger ( $\sim 80$ times) increase (Figure 4.14C). Thus, the Nafion-coated ITO shows excellent preconcentration of the cationic complex $\left[\mathrm{Ru}(\mathrm{bpy})_{3}\right]^{2+}$ as a model complex, and was explored further as discussed below. 

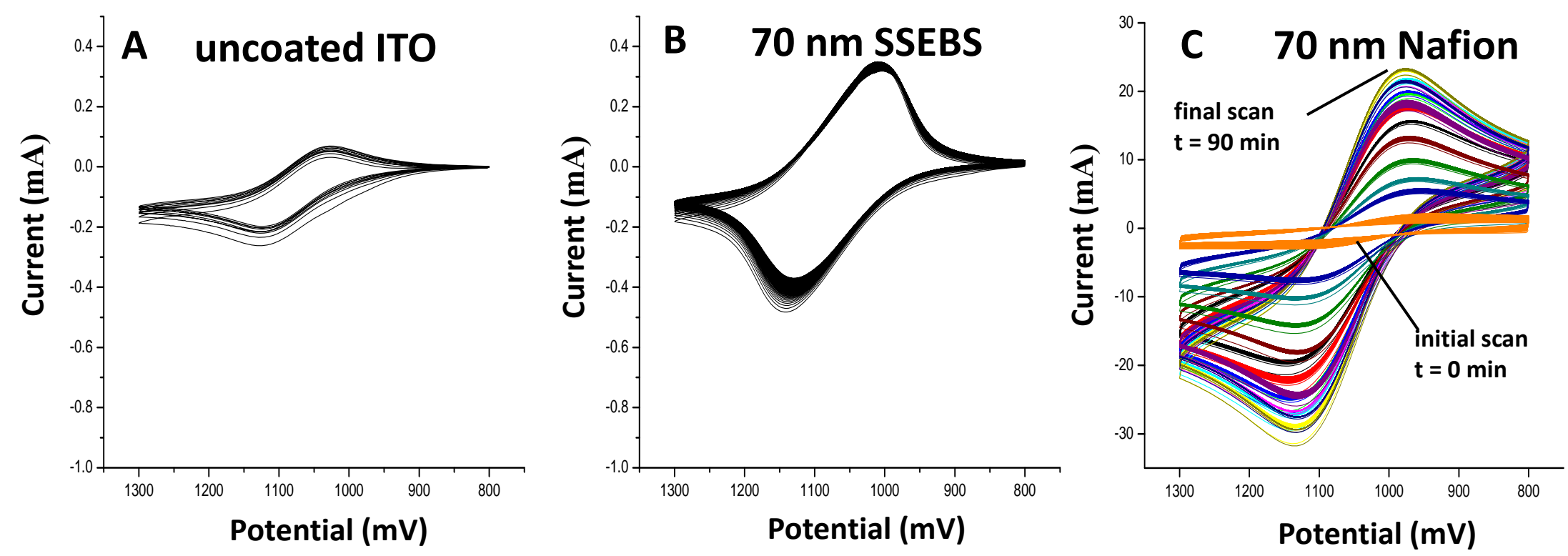

Figure 4.14. Cyclic Voltammagrams of A) $1 \mathrm{mM}\left[\mathrm{Ru}(\mathrm{bpy})_{3}\right]^{2+}$ on Bare ITO Electrode; B) Uptake of $1 \mathrm{mM}\left[\mathrm{Ru}(\mathrm{bpy})_{3}\right]^{2+}$ Into $70 \mathrm{~nm}$ Polymer SSEBS Film Coated on ITO; and C) Uptake of $1 \mathrm{mM}\left[\mathrm{Ru}(\mathrm{bpy})_{3}\right]^{2+}$ Into $70 \mathrm{~nm}$ Polymer Nafion Film Coated on ITO. Conditions include $0.1 \mathrm{M} \mathrm{KCl}$ supporting electrolyte, scan rate $50 \mathrm{mV} / \mathrm{s}$, SSEBS and/or ITO working electrode, $\mathrm{BASi} \mathrm{Ag} / \mathrm{AgCl}$ reference electrode, and a Pt wire auxiliary electrode. 
An experiment designed to demonstrate the effect of variable film thickness was performed using a series of ITO coated slides with Nafion material. Figure 4.15 and Figure 4.16 contain the cyclic voltammagrams taken during a 90 -minute equilibration in a solution containing no analyte metal (Figure 4.15) or in $10 \mu \mathrm{M}\left[\mathrm{Ru}(\mathrm{bpy})_{3}\right]^{2+}$ analyte (Figure 4.16) using three film thicknesses: (A) a bare ITO; (B) $25 \mathrm{~nm}$ polymer Nafion film coated on ITO; and (C) $200 \mathrm{~nm}$ polymer Nafion film coated on ITO. For the blank experiment shown in Figure 4.15 (no $\left[\mathrm{Ru}(\mathrm{bpy})_{3}\right]^{2+}$ analyte added), there is no reversible electrochemical signal, and the charging current observed is moderately small as expected. For the experiment with $10 \mu \mathrm{M}\left[\mathrm{Ru}(\mathrm{bpy})_{3}\right]^{2+}$ (Figure 4.16), the signal observed on the bare electrode (Figure 4.16A) is almost non-detectable, but is increased by a factor of $\sim 10$ times when the $25 \mathrm{~nm}$ Nafion film is applied (Figure 4.16B), and increased by a factor of $\sim 100$ times when a $200 \mathrm{~nm}$ Nafion film is applied. The positive $\mathrm{Y}$-axis (current) observed in Figure 4.16 is the reduction wave for the $\left[\mathrm{Ru}(\mathrm{bpy})_{3}\right]^{2+/ 3+}$ redox couple, the negative $\mathrm{Y}$-axis (current) is the re-oxidation wave for the $\left[\mathrm{Ru}(\mathrm{bpy})_{3}\right]^{2+/ 3+}$ couple. In Figure 4.16, these waves are observed to increase as the film thickness increases, indicating the increase in preconcentration of analyte due to thicker film (larger capacity for ion exchange into film). There is no $\left[\mathrm{Ru}(\mathrm{bpy})_{3}\right]^{2+/ 3+}$ redox couple observed in the blank experiments (Figure 4.15). By the shape of the reduction wave associated with negative $\mathrm{Y}$-axis (current) in Figure 4.15 at the potential approaching $\sim 1300$ to $1400 \mathrm{mV}$, and by the value of the potential of onset of current response ( $>1200 \mathrm{mV})$, it can be concluded that this current response is due to capacitance (charging) current only, and is not due to electrochemical reduction of analyte complex in solution. Clearly the increase in Nafion film coating has a large increase factor in electrochemical analyte detection on ITO using these model compounds. 

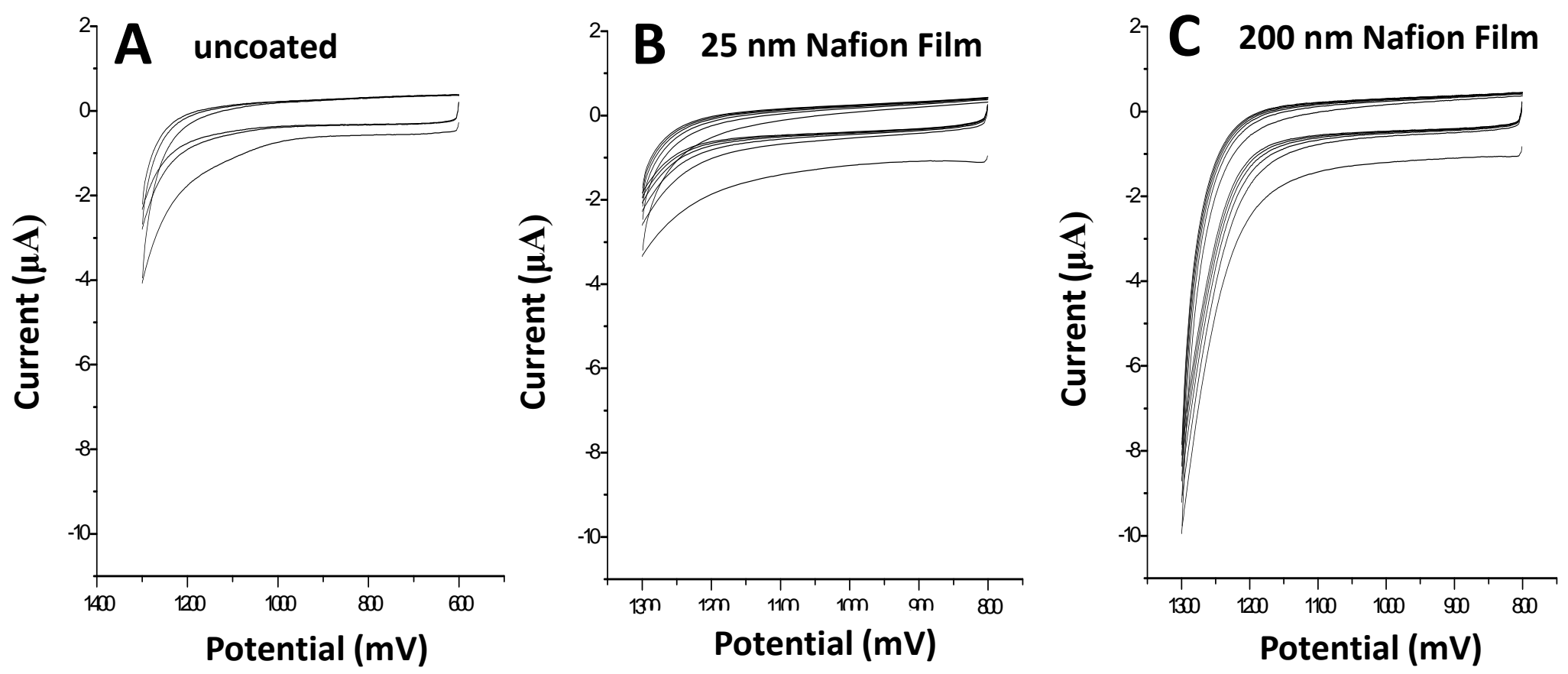

Figure 4.15. Background Cyclic Voltammagrams Taken During 90-minute Equilibration in Solution Containing No Analyte Metal Onto A) a Bare ITO; B) $25 \mathrm{~nm}$ Polymer Nafion Film Coated on ITO; and C) $200 \mathrm{~nm}$ Polymer Nafion Film Coated on ITO. Conditions include $0.1 \mathrm{M} \mathrm{KCl}$ supporting electrolyte, scan rate $50 \mathrm{mV} / \mathrm{s}$, Nafion on ITO working electrode, BASi Ag/AgCl reference electrode, and a Pt wire auxiliary electrode. 

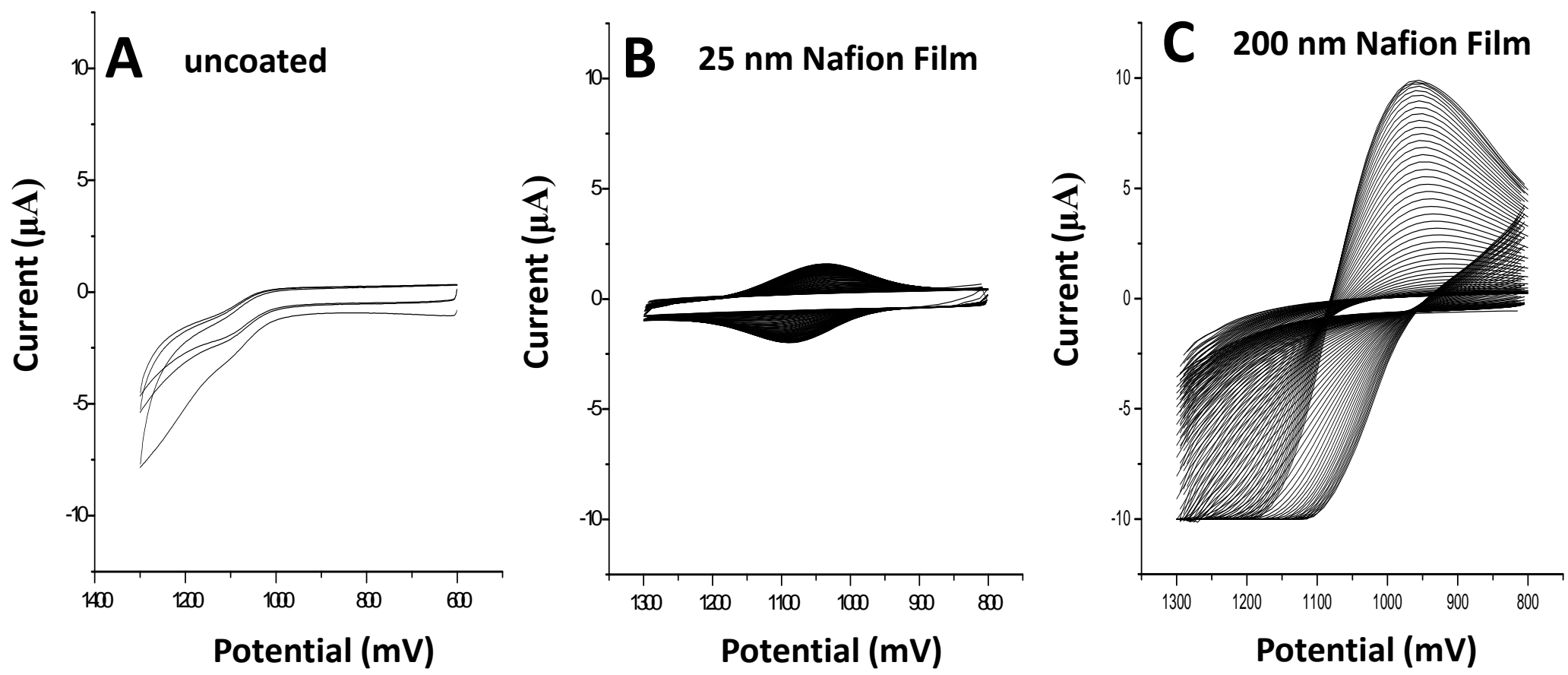

Figure 4.16. Cyclic Voltammagrams Taken During 90-minute Preconcentration of $10 \mu \mathrm{M}\left[\mathrm{Ru}(\mathrm{bpy})_{3}\right]^{2+}$ Onto A) a Bare ITO; B) $25 \mathrm{~nm}$ Polymer Nafion Film Coated on ITO; and C) 200 nm Polymer Nafion Film Coated on ITO. Conditions include 0.1 M KCl supporting electrolyte, scan rate $50 \mathrm{mV} / \mathrm{s}$, Nafion on ITO working electrode, $\mathrm{BASi} \mathrm{Ag} / \mathrm{AgCl}$ reference electrode, and a Pt wire auxiliary electrode. 
Figure 4.17 is a plot of anodic and cathodic peak currents from cyclic voltammagrams taken during 90-minute preconcentration of $10 \mu \mathrm{M}\left[\mathrm{Ru}(\text { bpy })_{3}\right]^{2+}$ into A) $25 \mathrm{~nm}$ polymer Nafion film coated on ITO; and B) $200 \mathrm{~nm}$ polymer Nafion film coated on ITO. These plots show the enhancement of electrochemical peak-current for the redox of the metal complex, as a function of time for the $25 \mathrm{~nm}$ and $200 \mathrm{~nm}$ Nafion films. The enhanced peak current is due to the increase in the concentration of the metal analyte complex partitioning into the selective ion-selective film, thereby increasing the ability to measure low-concentration analytes. Here, the $200 \mathrm{~nm}$ film has a $~ 8$ - to 10-fold increase in peak-current measurement over the $25 \mathrm{~nm}$ film, indicating that an increased level of detection is possible by moving to a thicker ion-selective film.

Preliminary experiments were performed for the selective uptake of Re-tricarbonyl complex into an ion-selective film. The preconcentration of the Re-carbonyl complex, $\left[\operatorname{Re}(\right.$ dmeobpy $\left.)(\mathrm{CO})_{3}\left(\mathrm{H}_{2} \mathrm{O}\right)\right] \mathrm{Br}$, using Nafion polymer film is shown in Figure 4.18. Cyclic voltammagrams taken during a 90-minute preconcentration of $1 \mathrm{mM}\left[\mathrm{Re}(\mathrm{dmeobpy})(\mathrm{CO})_{3}\left(\mathrm{H}_{2} \mathrm{O}\right)\right] \mathrm{Br}$ on either bare ITO (Figure 4.18A) or on a $70 \mathrm{~nm}$ polymer Nafion film coated on ITO (Figure 4.18B) are shown. The electrochemical reduction and oxidation potentials for the complex within the Nafion film (Figure 4.18B) are similar to those for the bare ITO electrode (Figure 4.18A), indicating that the Re-tricarbonyl complex is able to penetrate into the film, and also is able to be electrolyzed at the electrode. The electrochemical current for the Nafion-coated electrode is also increased over the bare electrode, indicating the enhancement due to preconcentration of $\left[\operatorname{Re}(\right.$ dmeobpy $\left.)(\mathrm{CO})_{3}\left(\mathrm{H}_{2} \mathrm{O}\right)\right] \mathrm{Br}$ within the ion-selective membrane. Further experiments will be performed to quantify the enhancement of Nafion, and also probe the effect of film thickness, film composition, and solvent contribution to preconcentration and detection. Conditions for this experiment include $0.1 \mathrm{M} \mathrm{TBAPF}_{6}$ in $\mathrm{MeCN}$ supporting electrolyte, scan rate $50 \mathrm{mV} / \mathrm{s}$, Nafion on ITO working electrode, $\mathrm{BASi} \mathrm{Ag} / \mathrm{AgCl}$ reference electrode, and $\mathrm{Pt}$ wire auxiliary electrode. 

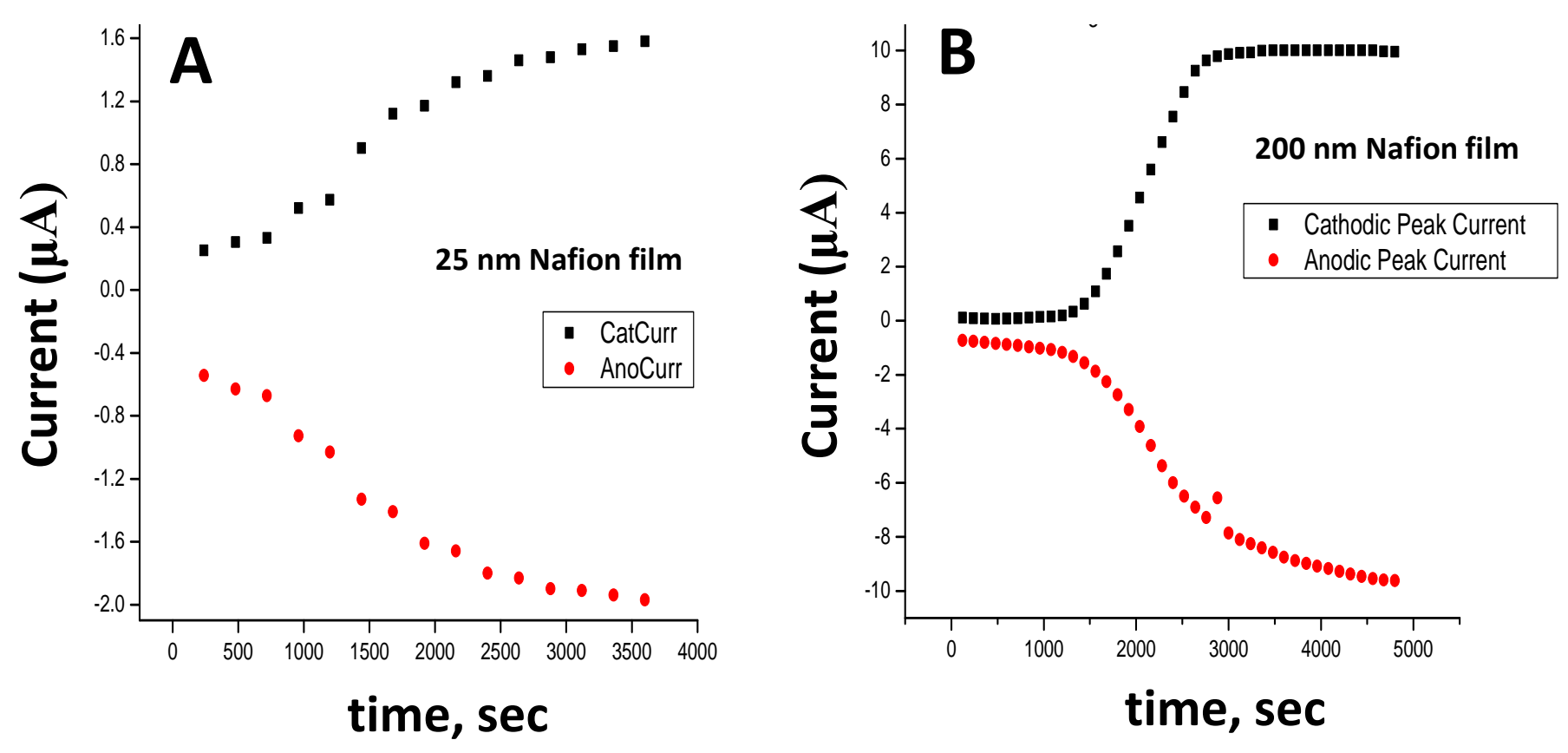

Figure 4.17. Plot of Anodic and Cathodic Peak Currents From Cyclic Voltammagrams Taken During 90-minute Preconcentration of $10 \mu \mathrm{M}$ $\left[\mathrm{Ru}(\mathrm{bpy})_{3}\right]^{2+}$ Onto A) $25 \mathrm{~nm}$ Polymer Nafion Film Coated on ITO; and B) $200 \mathrm{~nm}$ Polymer Nafion Film Coated on ITO. Conditions include $0.1 \mathrm{M} \mathrm{KCl}$ supporting electrolyte, scan rate $50 \mathrm{mV} / \mathrm{s}$, Nafion on ITO working electrode, BASi Ag/AgCl reference electrode, and a Pt wire auxiliary electrode. 

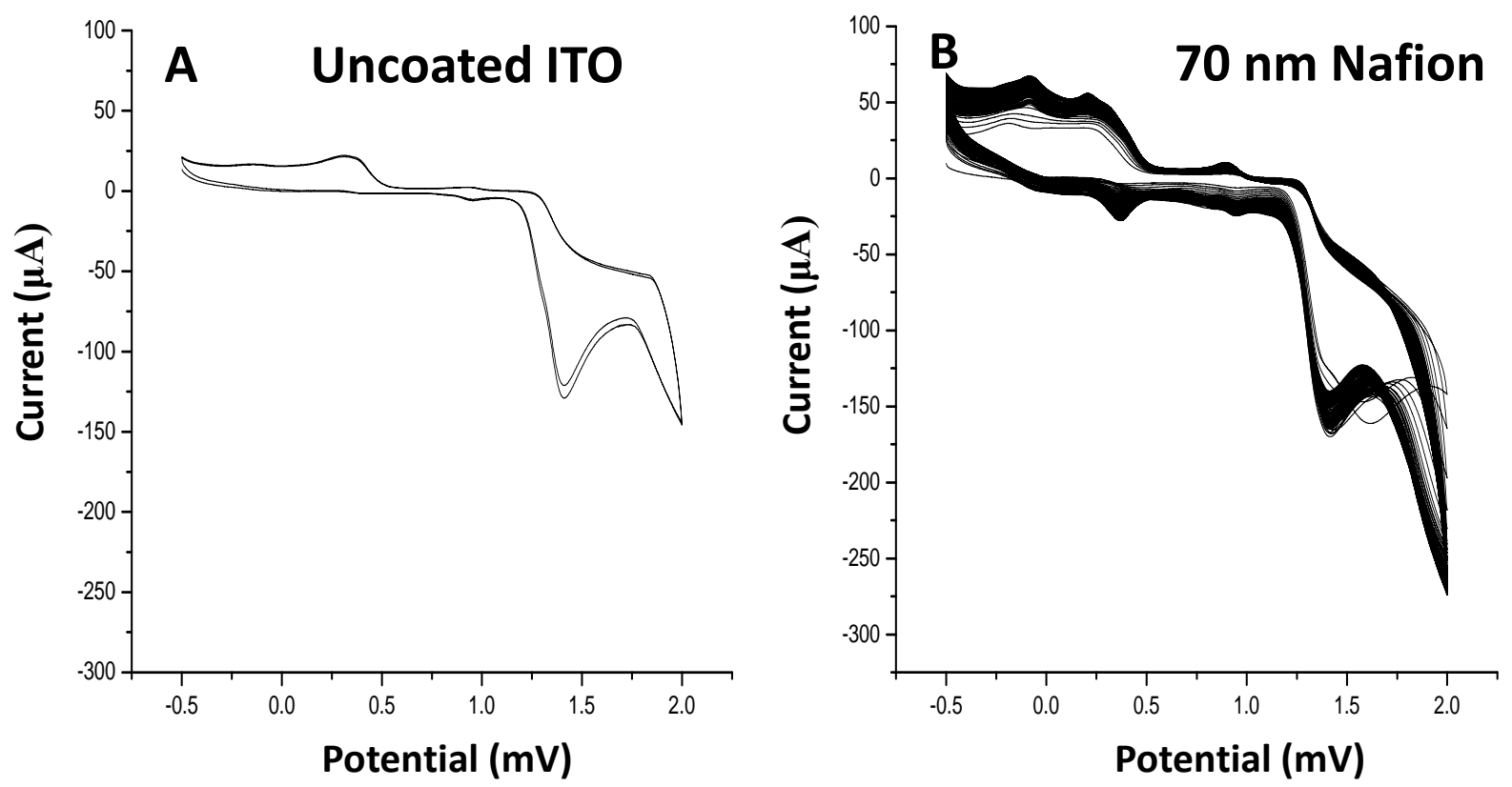

Figure 4.18. Cyclic Voltammagrams Taken During 90-minute Preconcentration of $1 \mathrm{mM}$ $\left[\operatorname{Re}(\right.$ dmeobpy $\left.)(\mathrm{CO})_{3}\left(\mathrm{H}_{2} \mathrm{O}\right)\right] \mathrm{Br}$ on $\left.\mathrm{A}\right)$ a Bare ITO; and B) a $70 \mathrm{~nm}$ Polymer Nafion Film Coated on ITO. Conditions include $0.1 \mathrm{M} \mathrm{TBAPF}_{6}$ in $\mathrm{MeCN}$ supporting electrolyte, scan rate $50 \mathrm{mV} / \mathrm{s}$, Nafion on ITO working electrode, BAS Ag/ $\mathrm{AgCl}$ reference electrode, and a Pt wire auxiliary electrode.

A demonstration of a prototype sensor utilizing the Nafion film with selective uptake of the model compound $\left[\mathrm{Ru}(\mathrm{bpy})_{3}\right]^{2+}$ was performed. Figure 4.19 shows a photograph of the prototype sensor. Labeled in the figure are the working electrode (WE), the reference electrode (RE), the auxiliary electrode (Aux), fiber optic leads, and sample inlet and outlets. The sample cell material is fabricated from Delrin ${ }^{\mathbb{B}}$ (a polyoxymethylene thermoplastic manufactured by Dupont ) and PVC, and contains a volume of $800 \mu \mathrm{L}$. Figure 4.20 is a schematic diagram of the prototype sensor (photo shown in Figure 4.19). Shown in this drawing are locations and the light path for excitation (incident fiber) and collection fibers. The analyte solution is positioned above the thin-film, which itself is layered on top of the ITO electrode. The ITO optically transparent electrode is mated to the glass light-guide substrate. The collection fiber optics are positioned for two modes of collection, one directly below the slide for emission measurements, and a second positioned at the end of the slide (beyond the coupling prism) for absorbance measurements. 


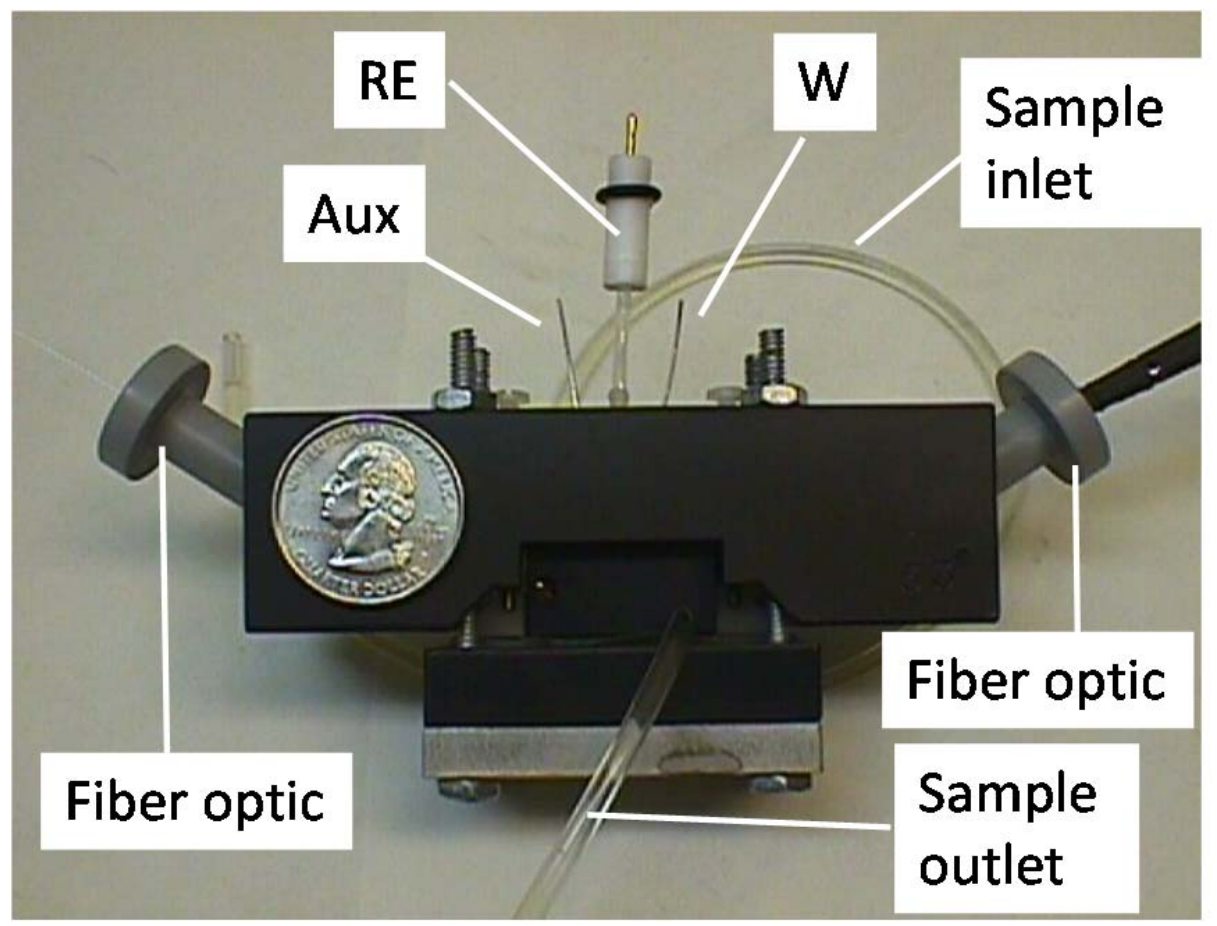

Figure 4.19. Photograph of Prototype Sensor. Labeled in figure are working electrode (W), reference electrode (RE), auxiliary electrode (Aux), fiber optic leads, and sample inlet and outlet. The sample cell material is fabricated from Delrin and PVC, and contains a volume of $800 \mu \mathrm{L}$. 


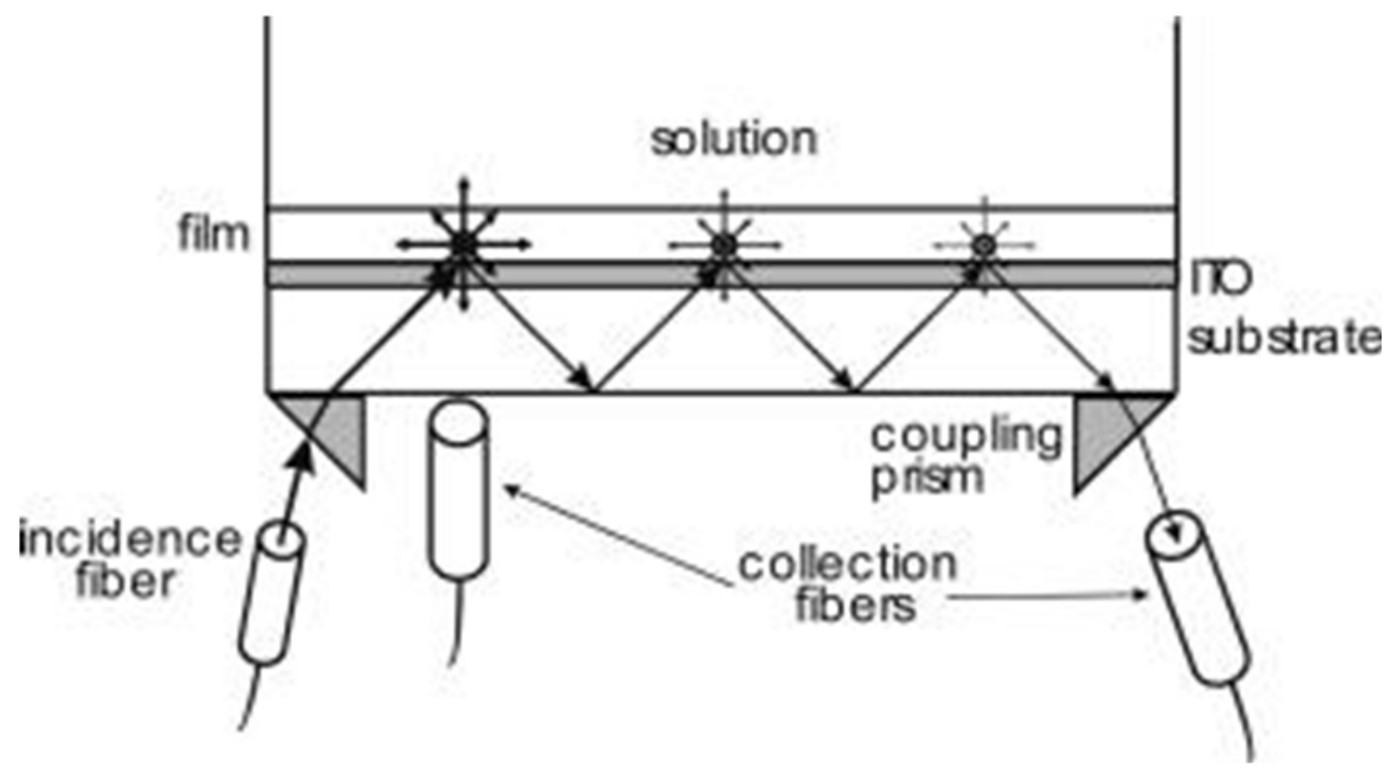

Figure 4.20. Schematic Diagram of Prototype Sensor. Shown in drawing are locations and light path for excitation (incident fiber) and collection fibers. The analyte solution is shown above the thin-film, layered on top of the ITO electrode, which is mated to the glass light-guide substrate. The collection fiber optics are positioned for two modes of collection, directly below the slide for emission measurements, and at the end of the slide (beyond the coupling prism) for absorbance measurements.

A spectroelectrochemical measurement utilizing the flow cell described above, with $\left[\mathrm{Ru}(\mathrm{bpy})_{3}\right]^{2+}$ as the model compound, was performed. Figure 4.21A contains the cyclic voltammagrams with the applied potential of $+1.2 \mathrm{~V}$ to $+0.90 \mathrm{~V}$, using $10 \mu \mathrm{M}\left[\mathrm{Ru}(\mathrm{bpy})_{3}\right]^{2+}$ with a $200 \mathrm{~nm}$ Nafion film on an ITO electrode. Figure $4.21 \mathrm{~B}$ is the optical emission response during the cyclic voltammagram sweep, showing the modulated emission response in step with the cyclic potential sweep with time. As the $\left[\mathrm{Ru}(\mathrm{bpy})_{3}\right]^{2 / 3+}$ complex is converted to the $\mathrm{Ru}(\mathrm{II})$ oxidation state upon reducing the electrode potential, the emission increases. As the $\mathrm{Ru}(\mathrm{III})$ oxidation state is formed upon increasing the applied electrode potential, the emission is quenched.

Work is currently ongoing for optimizing film composition and film thickness for use with Re-carbonyl and Tc-carbonyl systems. 

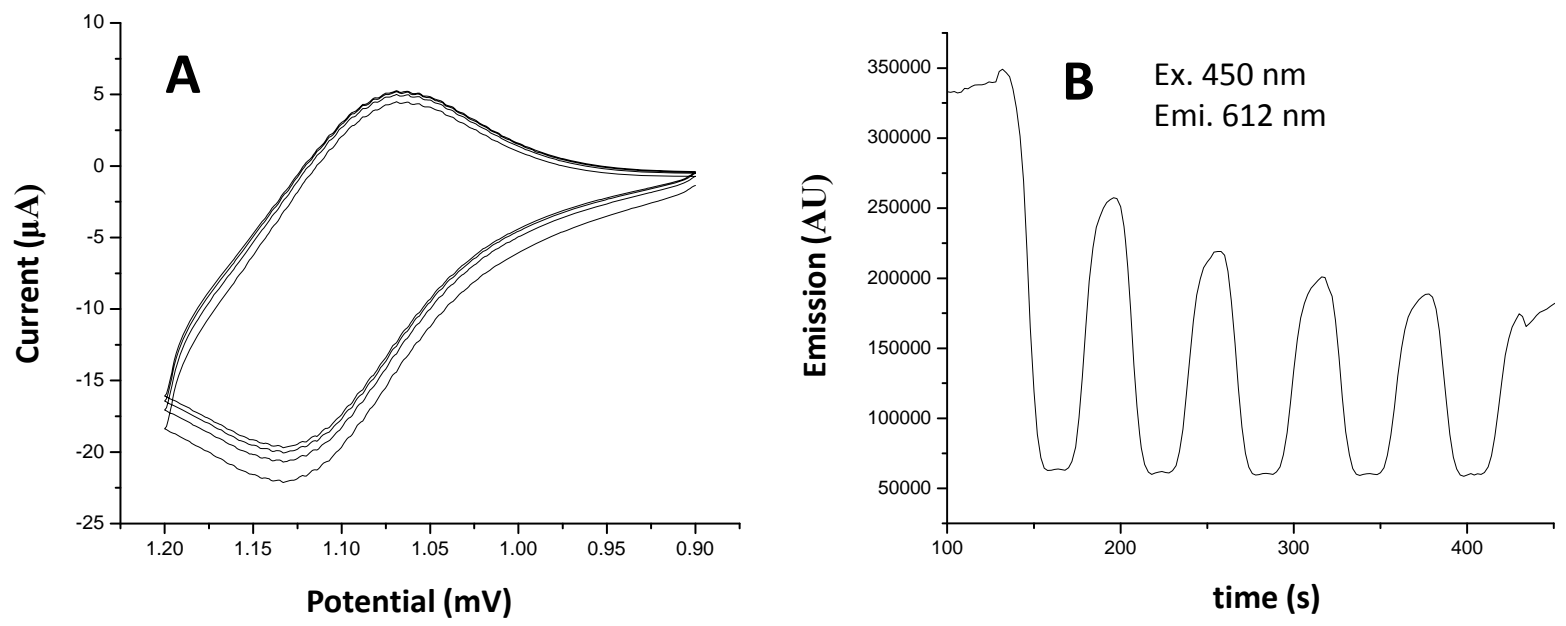

Figure 4.21. Spectroelectrochemical Measurement Using $\left[\mathrm{Ru}(\mathrm{bpy})_{3}\right]^{2+}$ as Model Compound to Test System. Conditions: $10 \mu \mathrm{M}\left[\mathrm{Ru}(\mathrm{bpy})_{3}\right]^{2+}, 200 \mathrm{~nm}$ Nafion ITO slide working electrode, $\mathrm{Ag} / \mathrm{AgCl}$ reference electrode, platinum auxiliary electrode, with $0.1 \mathrm{M} \mathrm{KNO}_{3}$ supporting electrolyte. 



\subsection{References}

Alberto R. 2005. New organometallic technetium complexes for radiopharmaceutical imaging. Contrast Agents III: Radiopharmaceuticals - from Diagnostics to Therapeutics, 252: 1-44.

Alberto R, K Ortner, N Wheatley, R Schibli, and AP Schubiger. 2001. Synthesis and properties of boranocarbonate: A convenient in situ $\mathrm{CO}$ source for the aqueous preparation of [(TC)-T-99m(OH2)(3)(CO)(3)](+). Journal of the American Chemical Society, 123(13): 3135-3136.

Alberto R, R Schibli, A Egli, AP Schubiger, U Abram, and TA Kaden. 1998. A novel organometallic aqua complex of technetium for the labeling of biomolecules: Synthesis of $[\mathrm{Tc}-99 \mathrm{~m}(\mathrm{OH} 2)(3)(\mathrm{CO})(3)](+)$ from [(TcO4)-Tc-99m](-) in aqueous solution and its reaction with a bifunctional ligand. Journal of the American Chemical Society, 120(31): 7987-7988.

Andria SE, JN Richardson, N Kaval, I Zudans, CJ Seliskar, and WR Heineman. 2004.

Spectroelectrochemical Sensing Based on Multimode Selectivity Simultaneously Achievable in a Single Device. 17. Improvement in Detection Limits Using Ultrathin Perfluorosulfonated Ionomer Films in Conjunction with Continuous Sample Flow. Analytical Chemistry, 76(11): 3139-3144.

Angelici RJ, and AE Kruse. 1970. Synthesis and Reactions of Carbomoyl Carbonyl Complexes of Rhenium (I). Journal of Organometallic Chemistry, 22: 461-471.

Chatterjee S, AS Del Negro, MK Edwards, SA Bryan, N Kaval, N Pantelic, LK Morris, WR Heineman, and CJ Seliskar. 2011a. Luminescence-Based Spectroelectrochemical Sensor for $[\mathrm{Tc}(\mathrm{dmpe})(3)](2+/+)$ (dmpe=1,2-bis(dimethylphosphino)ethane) within a Charge-Selective Polymer Film. Analytical Chemistry, 83(5): 1766-1772.

Chatterjee S, AS Del Negro, FN Smith, ZM Wang, SE Hightower, BP Sullivan, WR Heineman, CJ Seliskar, and SA Bryan. 2013. Photophysics and Luminescence Spectroelectrochemistry of $[\mathrm{Tc}(\mathrm{dmpe})(3)](+/ 2+)(\mathrm{dmpe}=1,2$-bis(dimethylphosphino)ethane). Journal of Physical Chemistry A, 117(48): 12749-12758.

Chatterjee S, AS Del Negro, ZM Wang, MK Edwards, FN Skomurski, SE Hightower, JA Krause, B Twamley, BP Sullivan, C Reber, WR Heineman, CJ Seliskar, and SA Bryan. 2011b. Electronic and Molecular Structures of trans-Dioxotechnetium(V) Polypyridyl Complexes in the Solid State. Inorganic Chemistry, 50(12): 5815-5823.

Deangelis TP and WR Heineman. 1976. Electrochemical Experiment Using an Optically Transparent Thin-Layer Electrode. Journal of Chemical Education, 53(9): 594-597.

Del Negro AS, CJ Seliskar, WR Heineman, SE Hightower, SA Bryan, and BP Sullivan. 2006. Highly oxidizing excited states of Re and Tc complexes. Journal of the American Chemical Society, 128(51): 16494-16495.

Del Negro AS, ZM Wang, CJ Seliskar, WR Heineman, BP Sullivan, SE Hightower, TL Hubler, and SA Bryan. 2005. Luminescence from the trans-Dioxotechnetium(V) chromophore. Journal of the American Chemical Society, 127(43): 14978-14979. 
Deng Y, CJ Seliskar, and WR Heineman. 1997. Electrochemical Behavior of $\left[\operatorname{Re}^{\mathrm{I}}(\mathrm{DMPE})_{3}\right]^{+}$, Where DMPE $=1,2$-Bis(dimethylphosphinoethane, at Perfluorosulfonated Ionomer-Modified Electrodes. Analytical Chemistry, 69(19): 4045-4450.

Deutsch E, K Lisbon, JL Vanderheyden, AR Ketring, and HR Maxon. 1986. The Chemistry of Rhenium and Technetium as Related to the Use of Isotopes of these Elements in Therapeutic and Diagnostic Nuclear Medicine. Nuc. Med. Biol., 13(4): 465-477.

DiVirgilio-Thomas JM, WR Heineman, and CJ Seliskar. 2000. Spectroelectrochemical Sensing Based on Multimode Selectivity Simultaneously Achievable in a Single Device. 6. Sensing with a Mediator. Analytical Chemistry, 72(15): 3461-3467.

Gao L and CJ Seliskar. 1998. Formulation, Characterization, and Sensing Applications of Transparent Poly(vinyl alcohol)-Polyelectrolyte Blends. Chemistry of Materials, 10: 2481-2489.

Gao L, CJ Seliskar, and WR Heineman. 1999. Spectroelectrochemical Sensing Based on Multimode Selectivity Simultaneously Achievable in a Single Device. 4. Sensing with Poly(vinyl alcohol)-Polyelectrolyte Blend Modified Optically Transparent Electrodes. Analytical Chemistry, 71(18): 4061-4068.

Gao L, CJ Seliskar, and WR Heineman. 2001. Spectroelectrochemical Sensing Based on Multimode Selectivity Simultaneously Achievable in a Single Device. 8. Selectivity at Poly(vinyl alcohol)-Polyelectrolyte Blend Modified Optically Tansparent Electrodes. Electroanalysis, 13(8-9): 613-620.

Haiyang H, M Lipowaska, X Xu, AT Taylor, M Carlone, and LG Marzilli. 2005. $\operatorname{Re}(\mathrm{CO})_{3}$ Complexes Synthesized via an Improved Preparation of Aqueous fac- $\left[\operatorname{Re}(\mathrm{CO})_{3}\left(\mathrm{H}_{2} \mathrm{O}\right)_{3}\right]^{+}$as an Aid in Assessing ${ }^{99 \mathrm{~m}} \mathrm{Tc}$ Imaging Agents. Structural Characterization and Solution Behavior of Complexes with Thioether-Bearing Amino Acids as Tridentate Ligands. Inorganic Chemistry, 44(15): 5437-5446.

Kaval, N., Seliskar, C. J., \& Heineman, W. R. 2003. Spectroelectrochemical Sensing Based on Multimode Selectivity Simultaneously Achievable in a Single Device. 16. Sensing by Fluorescence. Analytical Chemistry, 75(22): 6334-6340.

Kirchhoff JR, MR Allen, BV Cheesman, K Okamoto, WR Heineman, and E Deutsch. 1997. Electrochemistry and spectroelectrochemistry of $\left[\operatorname{Re}\left(1,2 \text {-bis(dimethylphosphino)ethane) }{ }_{3}\right]^{+}\right.$. Inorganica Chimica Acta, 262: 195-202.

Kirchhoff JR, WR Heineman, and E Deutsch. 1988. Technetium Electrochemistry. 6. Electrochemical Behavior of Cationic Rhenium and Technetium Complexes in Aqueous and Aqueous Micellar Solutions. Inorganic Chemistry, 27: 3608-1614.

Kissinger PT and WR Heineman. 1996. Laboratory Techniques in Electroanalytical Chemistry (2nd edition ed.). New York, New York: Marcel Dekkar, Inc.

Kurz P, B Probst, B Spingler, and R Alberto. 2006. Ligand variations in [ReX(diimine)(CO)(3)] complexes: Effects on photocatalytic CO2 reduction. European Journal of Inorganic Chemistry(15): 2966-2974. 
Lazarova N, S James, J Babich, and J Zubieta. 2004. A Convient Synthesis, Chemical Characterization and Reactivity of $\left[\operatorname{Re}(\mathrm{CO})_{3}\left(\mathrm{H}_{2} \mathrm{O}\right)_{3}\right] \mathrm{Br}$ : the Crystal and Molecular Structure of $\left[\mathrm{Re}(\mathrm{CO})_{3}\left(\mathrm{CH}_{3} \mathrm{CN}\right)_{2} \mathrm{Br}\right.$. Inorganic Chemistry Communications, 7: 1023-1026.

Lisbon K, M Woods, JC Sullivan, JW Watkins II, RC Elder, and E Deutsch. 1988. Electron-Transfer Reactions of Technetium and Rhenium Complexes. 2. Relative Self-Exchange Rate of the M(I)/M(II) Couples $\left[\mathrm{M}(\mathrm{DMPE})_{3}\right]^{+/ 2+}$, Where $\mathrm{M}=\mathrm{Tc}$ or Re and DMPE $=1,2-\mathrm{Bis}$ (dimethylphosphino)ethane. Inorganic Chemistry, 27: 999-1003.

Long GL and JD Winefordner. 1983. Limit of Detection. Analytical Chemistry, 55(7): A712-A724.

Lukens WW, DK Shuh, NC Schroeder, and KR Ashley. 2004. Identification of the non-pertechnetate species in Hanford waste tanks, Tc(I)-carbonyl complexes. Environmental Science \& Technology, 38(1): 229-233.

Maizels M, CJ Seliskar, WR Heineman, and SA Bryan. 2002. Spectroelectrochemical Sensing Based on Multimode Selectivity Simultaneously Achievable in a Single Device. 10. Sensing of Ferrocyanide in Hanford Tank Waste Simulant Solution. Electroanalysis, 14(19-20): 1345-1352.

Pantelic N, SE Andria, WR Heineman, and CJ Seliskar. 2009. Characterization of Partially Sulfonated Polystyrene-block-poly(ethylene-ran-butylene)-block-polystyrene Thin Films for Spectroelectrochemical Sensing. Analytical Chemistry, 81(16): 6756-6764.

Rapko BM, SA Bryan, S Chatterjee, MK Edwards, TG Levitskaia, JM Peterson, RA Peterson, and SI Sinkov. 2013. Investigations into the Nature of Alkaline Soluble, Non-Pertechnetate Technetium. PNNL-22957, Pacific Northwest National Laboratory, Richland, WA.

Richter MM, JD Debad, DR Striplin, GA Crosby, and AJ Bard. 1996. Electrogenerated chemiluminescence .59. Rhenium complexes. Analytical Chemistry, 68(24): 4370-4376.

Roodt A, JC Sullivan, D Meisel, and E Deutsch. 1991. Electron-Transfer Reactions of Technetium and Rhenium Complexes. 3. Pulse Radiolysis Studies on trans- $\left[\mathrm{M}^{\mathrm{III}} \mathrm{X}_{2}(\mathrm{DMPE})_{2}\right]^{+}$and $\left[\mathrm{M}^{\mathrm{I}}(\mathrm{DMPE})_{3}\right]^{+}$, Complexes in Aqueous and Aqueous Surfactant Media Where $\mathrm{M}=\mathrm{Tc}$ or $\mathrm{Re}, \mathrm{X}=\mathrm{Cl}$ or $\mathrm{Br}$, and $\mathrm{DMPE}=1,2-\mathrm{Bis}$ (dimethylphosphino)ethane. Inorganic Chemistry, 30: 4545-4549.

Salignac B, PV Grundler, S Cayemittes, U Frey, R Scopelliti, AE Merbach, R Hedinger, K Hegetschweiler, R Alberto, U Prinz, G Raabe, U Kolle, and S Hall. 2003. Reactivity of the Organometallic fac-[CO $\left.)_{3} \operatorname{Re}^{\mathrm{I}}\left(\mathrm{H}_{2} \mathrm{O}\right)_{3}\right]^{+}$Aquaion. Kinetic and Thermodynamic Properties of $\mathrm{H}_{2} \mathrm{O}$ Substitution. Inorganic Chemistry, 42(11): 3516-3526.

Schmidt SP, WC Trogler, F Basolo, MA Urbancic, and JR Shapey. 1990. Pentacarbonylrhenium Halides. Hoboken, NJ: John Wiley \& Sons, Inc.

Schulte EH and P Scoppa. 1987. Sources and behavior of technetium in the environment. The Science of the Total Environment, 64: 163-179.

Schwochau K. 2000. Technetium Chemistry and Radiopharmaceutical Applications. Weinheim: Wiley-VCH. 
Shi Y, CJ Seliskar, and WR Heineman. 1997a. Spectroelectrochemical Sensing Based on Multimode Selectivity Simultaneousy Achievable in a Single Device. 2. Demonstration of Selectivity in the Presence of Direct Interferences. Analytical Chemistry, 69(23): 4819-4827.

Shi Y, AF Slaterbeck, S Aryal, CJ Seliskar, WR Heineman, TH Ridgway, and JH Nevin. 1998. New Spectroelectrochemical Sensor. SPIE, 3258: 56-65.

Shi Y, AF Slaterbeck, CJ Seliskar, and WR Heineman. 1997b. Spectroelectrochemical Sensing Based on Multimode Selectivity Simultaneously Achievable in a Single Device. 1. Demonstration of Concept with Ferricyanide. Analytical Chemistry, 69(18): 3679-3686.

Slaterbeck AF, TH Ridgway, CJ Seliskar, and WR Heineman. 1999. Spectroelectrochemical Sensing Based on Multimode Selectivity Simultaneously Achievable in a Single Device. 3. Effect of Signal Averaging on Limit of Detection. Analytical Chemistry, 71(6): 1196-1203.

Slaterbeck AF, ML Stegemiller, CJ Seliskar, TH Ridgway, and WR Heineman. 2000. Spectroelectrochemical Sensing Based on Multimode Selectivity Simultaneously Achievable in a Single Device. 5. Simulation of Sensor Response for Different Excitation Potential Waveforms. Analytical Chemistry, 72(22): 5567-5575.

Smieja JM and CP Kubiak. 2010. Re(bipy-tBu)(CO)(3)Cl-improved Catalytic Activity for Reduction of Carbon Dioxide: IR-Spectroelectrochemical and Mechanistic Studies. Inorganic Chemistry, 49(20): 9283-9289.

Verbruggen A. 2005. Radiopharmaceutical chemistry of technetium and rhenium. Paper presented at the EANM Congress.

Wang ZM, JM Zachara, PL Gassman, CX Liu, O Qafoku, W Yantasee, and JG Catalano. 2005a. Fluorescence spectroscopy of U(VI)-silicates and U(VI)-contaminated Hanford sediment. Geochimica Et Cosmochimica Acta, 69(6): 1391-1403.

Wang ZM, JM Zachara, JP McKinley, and SC Smith. 2005b. Cryogenic laser induced U(VI) fluorescence studies of a U(VI) substituted natural calcite: Implications to U(VI) speciation in contaminated Hanford sediments. Environmental Science \& Technology, 39(8): 2651-2659.

Wansapura CM, CJ Seliskar, and WR Heineman. 2007. Spectroelectrochemical Sensing Based on Multimode Selectivity Simultaneously Achievable in a Single Device. 20. Detection of Metal Ions in Different Oxidation States. Analytical Chemistry, 79: 5594.

Woolf AA. 1961. An Outline of Rhenium Chemistry. Quarterly Review of the Chemical Society, 15: 372. 
PNNL-23655

EMSP-RPT-025, Rev. 0

\section{Distribution*}

U.S. Department of Energy

Office of Environmental Management

NP Machara

JA Poppiti

SP Schneider

DOE Office of River Protection

JA Diediker

TW Fletcher

BJ Harp

BM Mauss

SH Pfaff

Washington River Protection Solutions

PA Cavanah

KN Subramanian

DJ Swanberg

LE Thompson

Savannah River National Laboratory

SL Marra

DJ McCabe

WR Wilmarth

University of Cincinnati

SD Branch

WR Heineman

\author{
Pacific Northwest National Laboratory \\ PR Bredt \\ CF Brown \\ SA Bryan \\ TG Levitskaia \\ RA Peterson \\ N Qafoku \\ BM Rapko \\ SN Schlahta \\ RJ Serne \\ GL Smith \\ DM Wellman \\ JH Westsik, Jr.
}




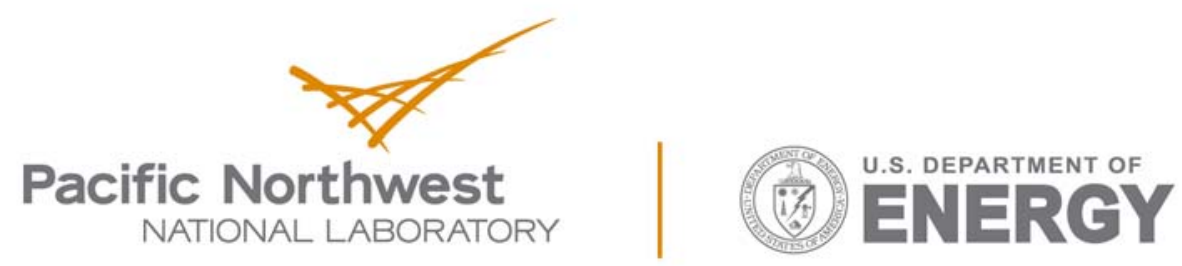

Proudly Operated by Battelle Since 1965

902 Battelle Boulevard

P.O. Box 999

Richland, WA 99352

1-888-375-PNNL (7665)

www.pnnl.gov 